\title{
WestVirginiaUniversity
}

THE RESEARCH REPOSITORY @ WVU

Graduate Theses, Dissertations, and Problem Reports

2012

\section{Foreign Christian Influence in Developing World Domestic Social Policy}

William Harrison

West Virginia University

Follow this and additional works at: https://researchrepository.wvu.edu/etd

\section{Recommended Citation}

Harrison, William, "Foreign Christian Influence in Developing World Domestic Social Policy" (2012).

Graduate Theses, Dissertations, and Problem Reports. 4863.

https://researchrepository.wvu.edu/etd/4863

This Dissertation is protected by copyright and/or related rights. It has been brought to you by the The Research Repository @ WVU with permission from the rights-holder(s). You are free to use this Dissertation in any way that is permitted by the copyright and related rights legislation that applies to your use. For other uses you must obtain permission from the rights-holder(s) directly, unless additional rights are indicated by a Creative Commons license in the record and/ or on the work itself. This Dissertation has been accepted for inclusion in WVU Graduate Theses, Dissertations, and Problem Reports collection by an authorized administrator of The Research Repository @ WVU.

For more information, please contact researchrepository@mail.wvu.edu. 


\title{
Foreign Christian Influence in Developing World Domestic Social Policy
}

\author{
William Harrison \\ Department of Political Science \\ West Virginia University \\ Dissertation submitted to the Eberly College of Arts and Sciences \\ at West Virginia University \\ in partial fulfillment of the requirements \\ for the degree of
}

Doctor of Philosophy in

Political Science

Dr. R. Scott Crichlow, Chair

Dr. Robert Duval

Dr. Karleen West

Dr. Joe Hagan

Dr. James Siekmeier

Department of Political Science

Morgantown, West Virginia

2012

Keywords: Christian Influence; Developing World; Social Policy

Copyright 2012 William Harrison 


\title{
ABSTRACT \\ Foreign Christian Influence in Developing World Domestic Social Policy
}

\author{
William Harrison
}

There is a debate going on in the United States today about where our culture is headed. In the United States and much of the West, society is becoming more liberal on issues such as gay rights and abortion. In countries of the developing in Africa and Latin America there has also been a debate about these issues. This is in part fueled by Christian groups coming from outside of the countries of the developing world who are attempting to export the Culture Wars of the West to the developing world. This paper theorizes that foreign Christian groups have a more difficult time influencing social policy, specifically gay rights and abortion policy, in developing countries that possess higher state capacity. Conversely these same groups have an easier time influencing policy in developing countries with a lower level of state capacity. This work will look at countries in the developing world from Latin America and Africa which have become battlegrounds in the exported Culture Wars. I find that foreign Christian groups do have an easier time influencing social policy in developing countries with lower state capacity and a more difficult time influencing social policy in developing countries with a higher level of state capacity. This is important for the field of Political Science in that it increases our knowledge of non-governmental organizations. 


\section{DEDICATION}

This dissertation is dedicated to all three of my parents Bill, Elyse, and Mary. I love you all. 


\section{ACKNOWLEDGEMENTS}

I would like to acknowledge and thank my committee members Dr. Crichlow, Dr. Hagan, Dr. Duval, Dr. West, and Dr. Siekmeier for all of their help during this process. I would also like to thank my Parents Bill, Elyse, and Mary as well as all of my family and

friends. I would like to thank Dr. Worsham and Dr. MacDonald for being great graduate directors. Finally, I would like to thank Lee Ann Greathouse, Ronny Thompson, and Donna MacIsaac for all of their help over the years. 


\section{TABLE OF CONTENTS}

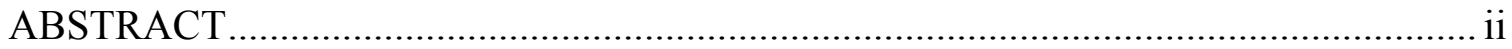

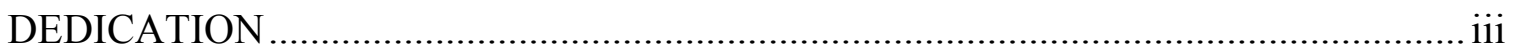

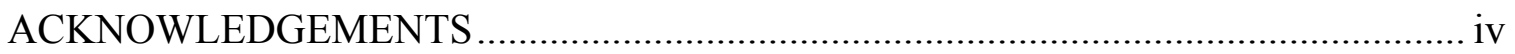

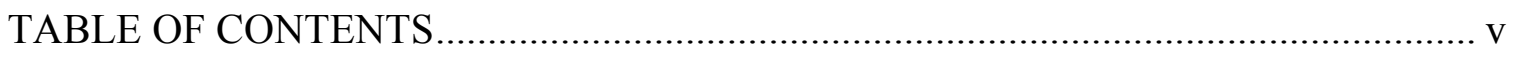

LIST OF FIGURES …………………..............................................................

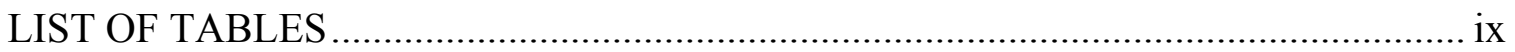

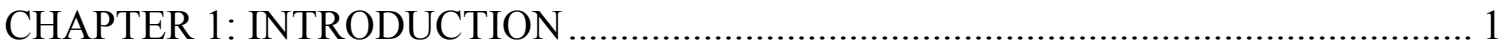

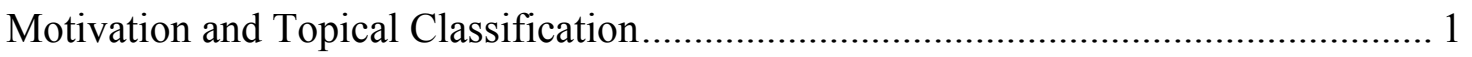

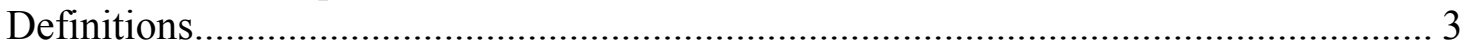

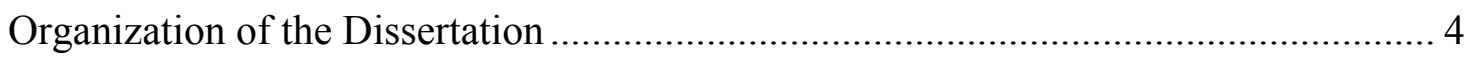

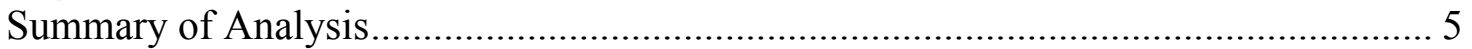

Applicability for This Study …………………………………………………… 7

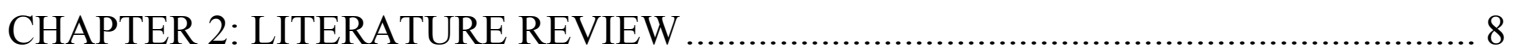

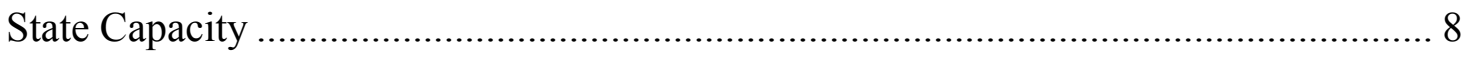

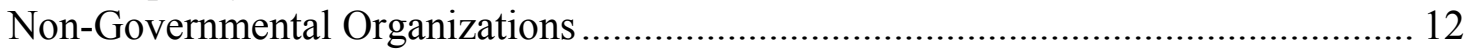

Religious Groups Working Abroad ....................................................................... 15

Social Movements Affecting Public Policy ………………......................................... 17

Religiosity and Human Development ..................................................................... 20

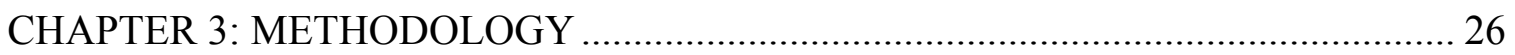

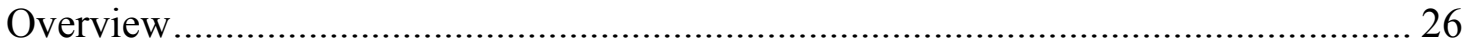

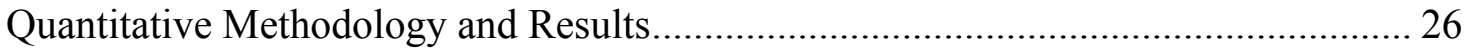

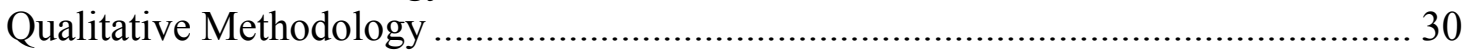

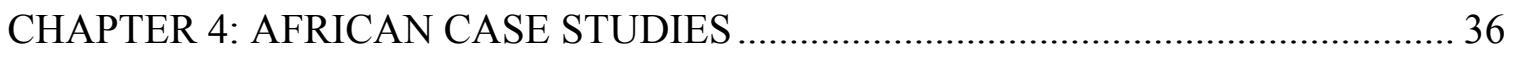

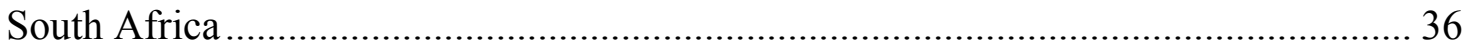

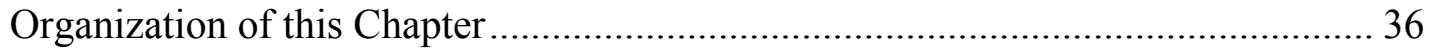

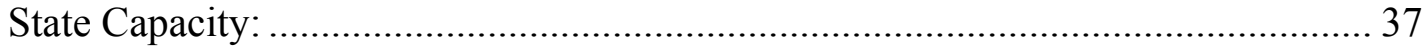

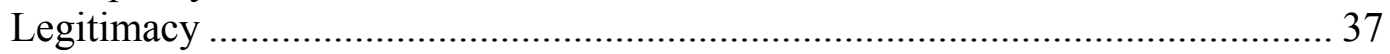

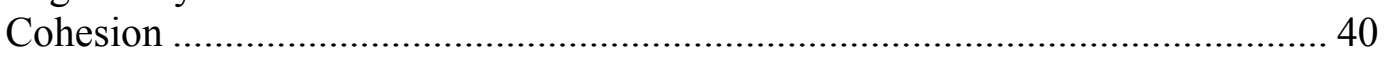

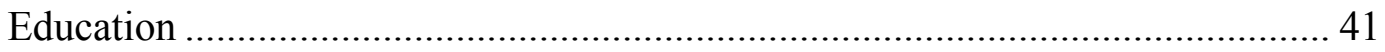

Foreign Christian Effort Directed at South Africa.................................................. 42

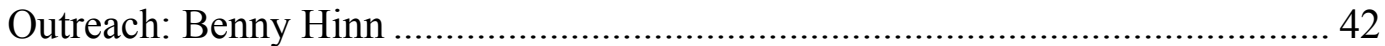

Outreach: Association of Baptists for World Evangelism..................................... 43

Outreach: Kenneth Hagin Ministries ................................................................. 45

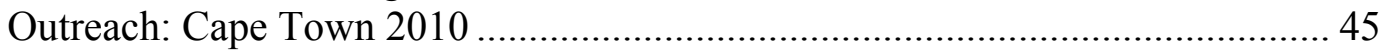

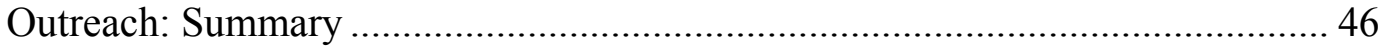

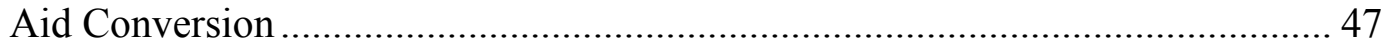

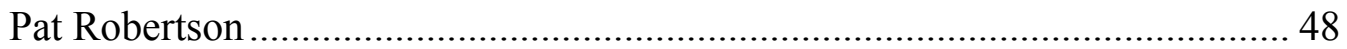

Franklin Graham and Samaritans Purse........................................................... 48

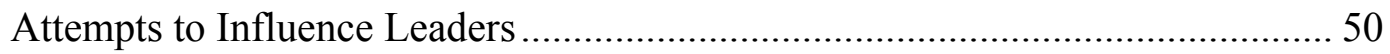

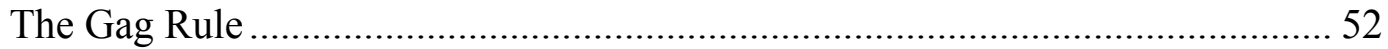




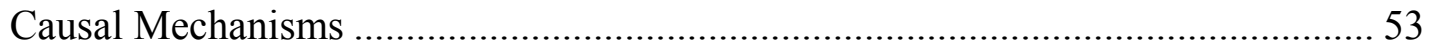

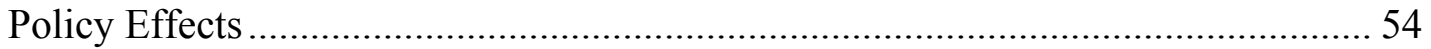

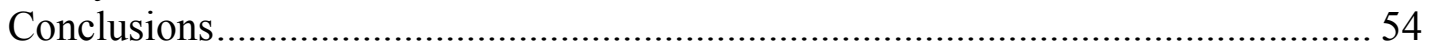

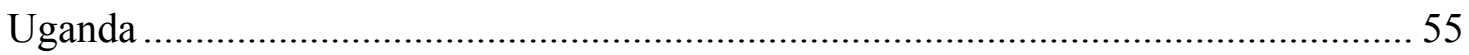

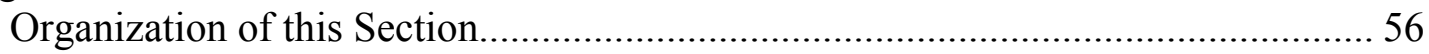

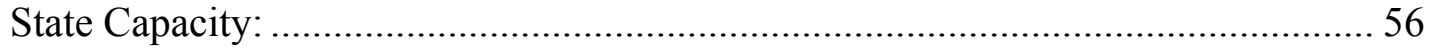

Domestic Factors: A Low Functioning State....................................................... 56

Domestic Factors: Lords Resistance Army........................................................ 57

Domestic Factors: Religious Conflicts ………………...................................... 57

Domestic Factors: Civil War .............................................................................. 57

Legitimacy: The President Museveni Regime.................................................... 58

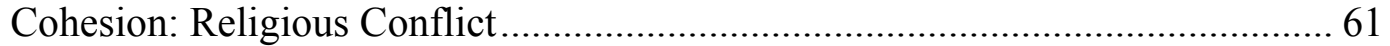

Cohesion: Exploiting A Common Enemy ............................................................ 63

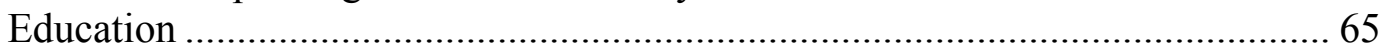

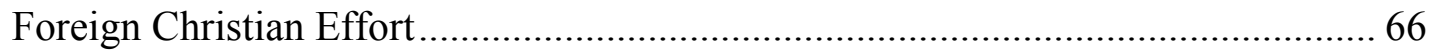

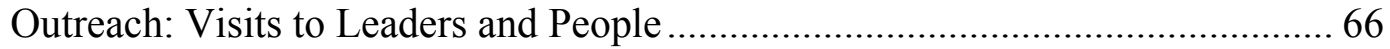

Exploitation of Aid Channels: United States Influence ......................................... 69

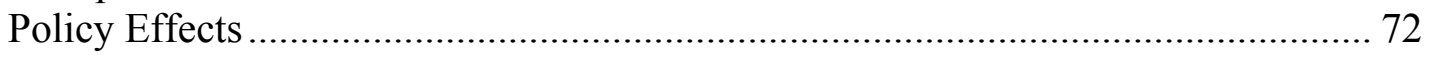

Attempts to Change Homosexual Policies........................................................... 72

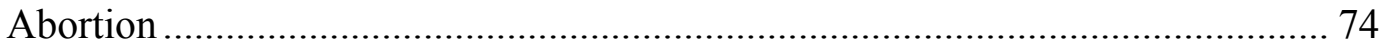

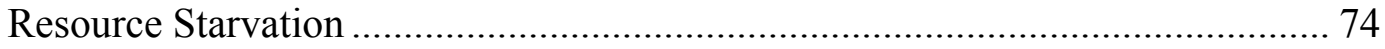

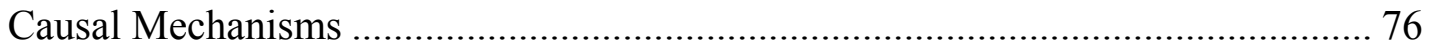

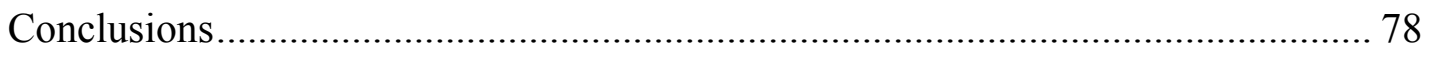

CHAPTER 5: LATIN AMERICAN CASE STUDIES ……………………………...... 79

Discussion of Foreign Christian Effort against Homosexuality .................................. 79

Overview of Catholic Indigenousness A discussion of how Catholicism is foreign 79

Catholic Belief on Homosexuality........................................................................ 81

Foreign Role in the Latin American Abortion Debate................................................ 81

Latin American Adventures .......................................................................... 82

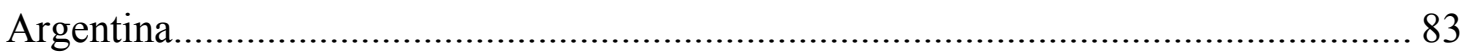

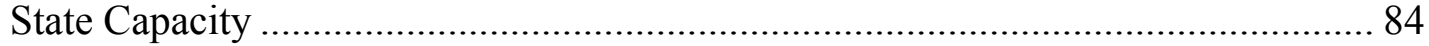

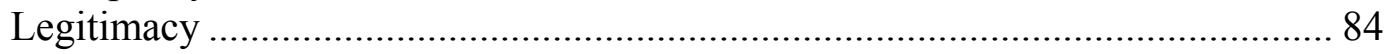

Background on the Kirchner's Economic Success ………………………........ 85

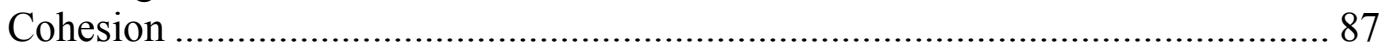

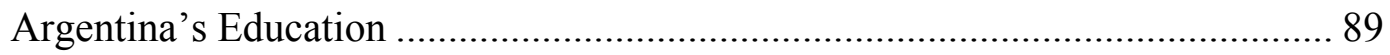

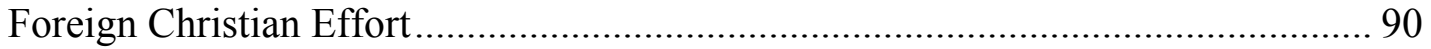

Special Role of the Catholic Church.................................................................. 90

Effort to Reach Citizens of Argentina ............................................................... 91

Attempts to Influence Government Directly........................................................ 94

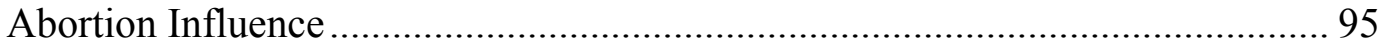

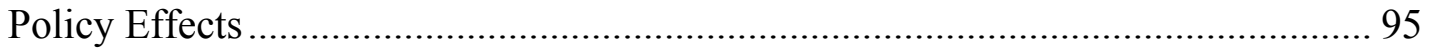

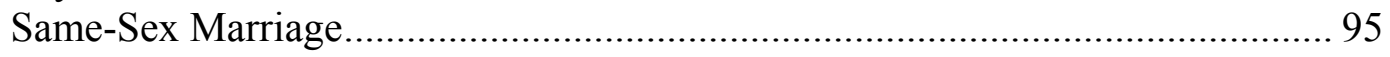

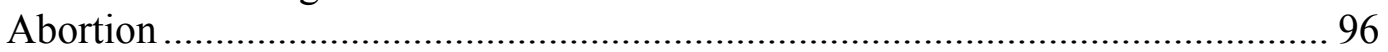

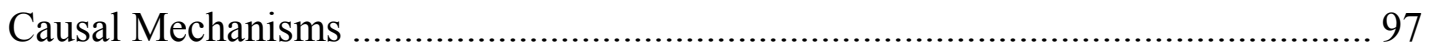

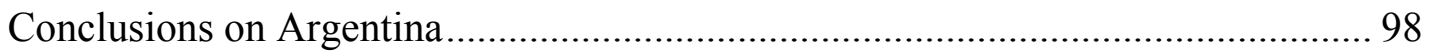

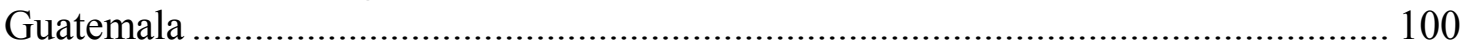




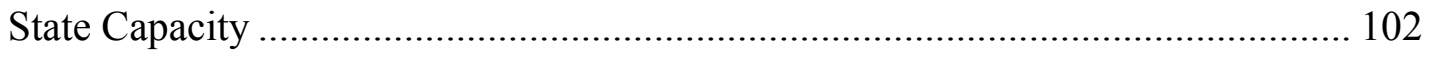

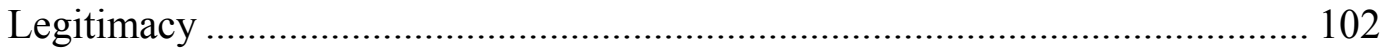

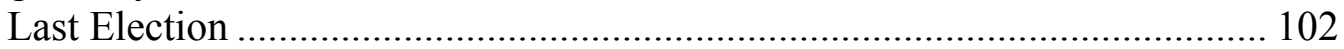

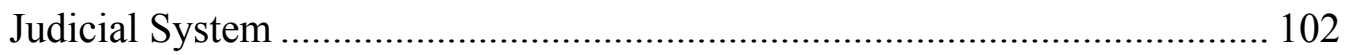

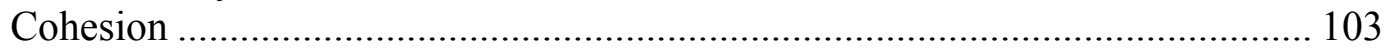

Religious Response to Violence ............................................................ 106

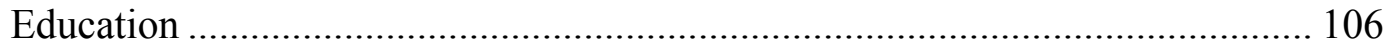

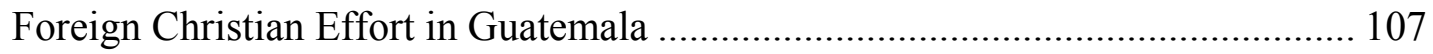

Protestantism in Guatemala ..................................................................... 107

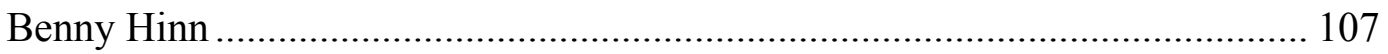

The Walton's Involvement in Guatemala .................................................... 108

Jorge Antonio Serrano Elías ........................................................................... 109

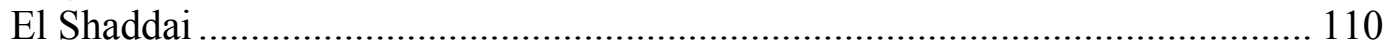

The Montt Regime ................................................................................... 111

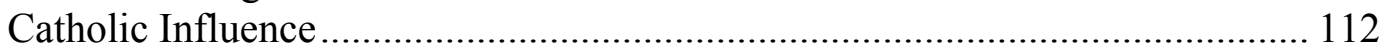

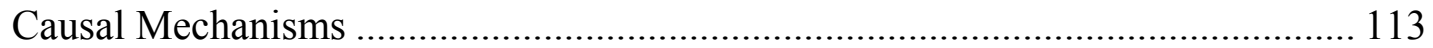

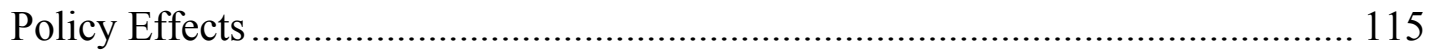

Gay Rights ...................................................................................... 115

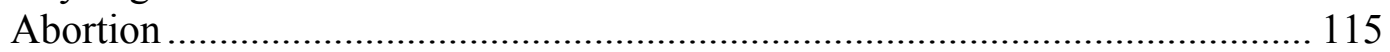

Conclusions on Guatemala ....................................................................... 116

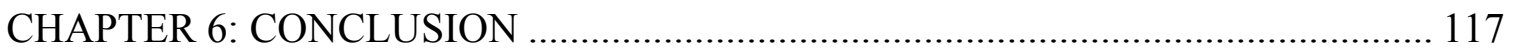

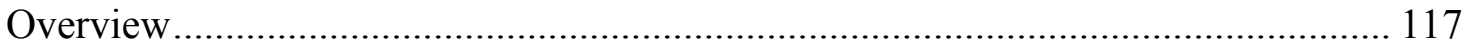

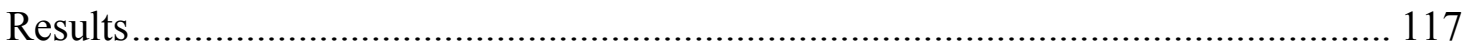

Where This Research Fits In ............................................................................... 118

Areas for Future Research ................................................................................... 119

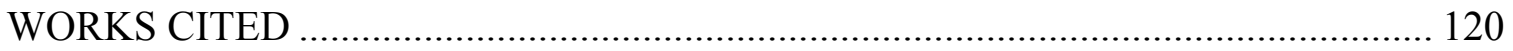

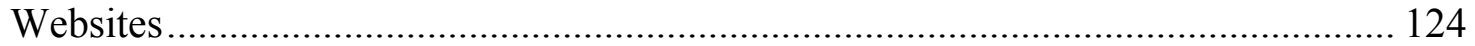

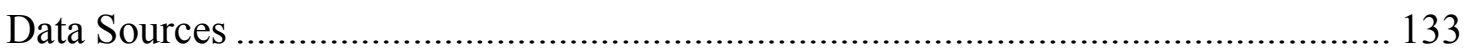

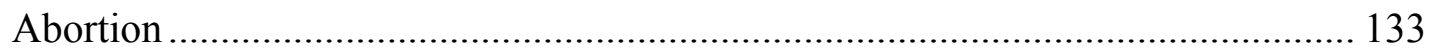

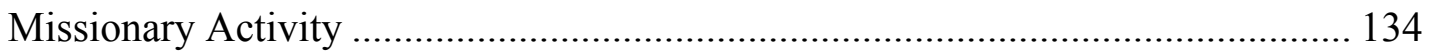

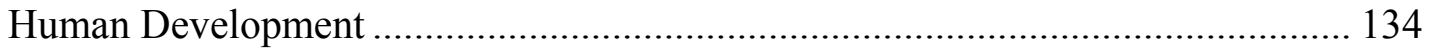




\section{LIST OF FIGURES}

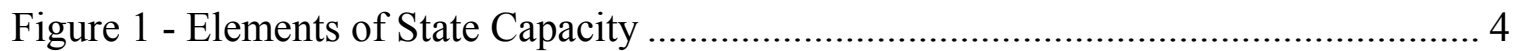

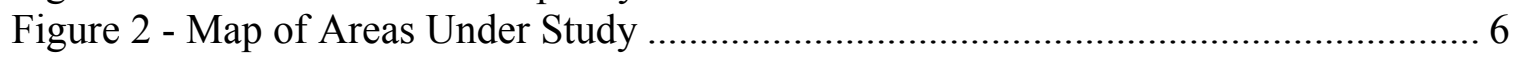

Figure 3 - Wealth and Religiosity ............................................................................... 22 


\section{LIST OF TABLES}

Table 1 - 1995 Correlation Between Human Development Index and Policy Area........ 29

Table 2 - 2000 Correlation Between Human Development Index and Policy Area........ 29

Table 3 - 2005 Correlation Between Human Development Index and Policy Area........ 29

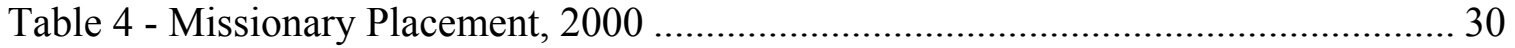




\section{CHAPTER 1: INTRODUCTION}

\section{MOTIVATION AND TOPICAL CLASSIFICATION}

This thesis fits within he general subject of the understanding of international influence and the transnational political activities of non-governmental organizations, and adds to our understanding of this area. The study of this interaction deals with how groups influence, fight, or interact with each other across borders. This is important in a world which is becoming smaller and thus countries are interacting more than ever before. The thesis also adds to our understanding of those who export the cultural wars of the West into the Developing World, as will be described in the next paragraph.

This work is important for political science and fits into the field in several respects. It fits into the literature regarding non-governmental organizations and nonstate actors, specifically religious non-governmental organizations and actors. A great deal of work has been done in the field of NGOs and non-state actors and some of the work done focuses on how NGOs work with the societies and governments of host countries. NGOs can be examined from several different points of view. NGOs aiming to help a society fall into roughly four categories: 1 . they provide humanitarian help to those in crisis. 2. They promote economic and social development where poverty is

present, 3. They monitor human rights. 4. Finally, they promote peace by helping provide methods of non-violent problem solving such as, negotiation techniques and nonviolence. (Anderson, 1996, 344) In this work we examine NGOs of a different sort those that exploit the help they give to both common people and elites by using it to foster particular religious views.

According to Aall (1996) some NGO's will work with institutions while others are more focused on grass roots efforts. Further, according to Commins (1993) many allow the target group to make important decisions. The NGOs we explore combine these aspects. They work with both the elite and with the grass roots of a country to implement policy positions they support.

The focus of this work is on NGOs that want to promote social development but in a way that is actually harmful to weak elements in society such as women and 
homosexuals. This differentiates them from NGO's whose sole purpose is to purely help in that there is an expected societal return for the help that is given. This is similar to the type Gilpin (2001) points to that attempt to affect the civil society as well as host governments. As such, they combine the ingredients of several differing kinds of NGO in order to effect policy change. What I examine here is how all of these differing methods are employed by the foreign Christian groups some emphasizing one style over another, to alter societal social policy in directions that they support.

This work looks at a specific type of NGO foreign Christian groups. The main goal of the research in this thesis is to demonstrate that the less functional a country is, the more susceptible to the penetration of foreign Christian ideology the people and the government of that country will be. In the face of efforts from foreign Christian groups, I would expect that, in turn, this will lead these states to adopt policies more in line with the priorities of these foreign Christian groups. I will use anti-homosexual and antifeminist policies as the indictors to exhibit the effects of foreign Christian influence. Thus, the main research question will be do foreign Christian groups have more success in influencing the policies on homosexuality and abortion/abstinence in less wellfunctioning countries than they do in better-functioning countries. This dissertation will demonstrate that they do. It will exhibit evidence to show: 1) that worse-off countries, on average, have more restrictive social policies on the issues of homosexual rights and abortion than do better off countries in the developing world, and 2) that there is effort by foreign Christian organizations in the countries in question, i.e. countries of the developing world. Further, the foreign Christian effort has exerted influence to affect these social policies. These two facts demonstrate the correctness of my hypothesis. They do this because they show how the problems of worse-off counties go hand in hand with the efforts of foreign Christian groups to alter social policy in those countries. This is important for the field of International Relations due to the fact that it shows how nonstate actors such as NGO's have more of an effect in influencing domestic social policy in some types of developing countries as opposed to other types of developing countries.

The two main policies used as indicators of measure social policy are homosexual rights and abortion/abstinence issues, because both are important issues that these 
Christian groups care deeply about and about which I can expect they would attempt to influence policy in these areas if they could.

To examine the matter in depth, I will focus on a select number of countries, drawing pairs of more and less functional states from regions whose geopolitical characteristics are relatively similar. Not all countries pose the same set of issues to foreign Christian groups, regardless of level of functionality. This study will focus states that already have a sizable Christian population. Although anti-gay and anti-abortion laws exist in Islamic states as they also do in Christian countries, these states will not be included, because in their case this is as a result of their Islamic populations. Their policies have more to do with Islamic control and perspectives than they do with any Christian activities in the countries, and it can not be expected that foreign Christian groups would have as much success working in these countries as elsewhere. Similarly, in many portions of the developing world there are already powerful religions such as Hinduism or Buddhism, or states that are legally Communist/Atheist. These states have enacted their own social policies and these policies have little to do with Christianity. Due to the cultural/political control by the other groups in these areas they will not be included in this study. Instead, this study will focus on Sub-Saharan Africa and Latin America. These are regions of the developing world with sizeable populations where Christianity can be expected to have a noticeable effect.

\section{DEFINITIONS}

As stated above, the main question will be whether developing countries with lower state capacity will be more open to outside Christian than those with higher state capacity

Important terms used in this work are: state capacity, foreign Christian effort, foreign Christian groups, and domestic groups.

State capacity, as defined by Skocpol is a state's ability or lack thereof to effectively administer the territory it is responsible. (CDL) For purposes of this work, the definition is made specific to include: legitimacy, cohesion, education and the general domestic factors affecting the state, such as war and poverty. Further, it will include the Human Development Index as published by the United Nations. The elements of state capacity as used in this document are shown below. 


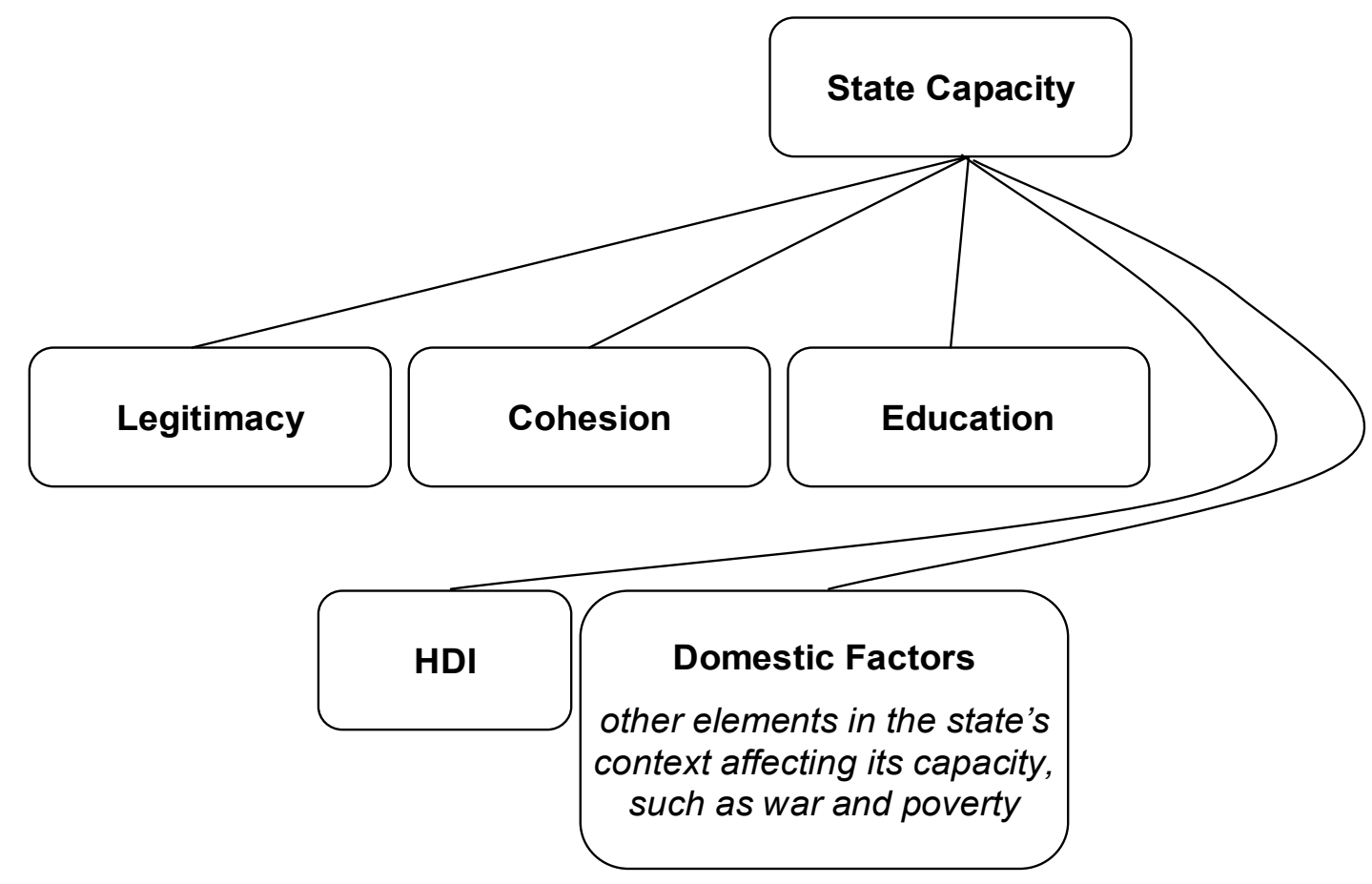

Figure 1 - Elements of State Capacity

Foreign Christian effort is defined as factors that go into attempts by foreign Christian groups to enter a country and influence policy and public opinion. These factors include both money, and personal contacts between foreign Christian groups and leaders and people of the states in question. Money may come directly from foreign Christian groups or from governments influenced by foreign Christian groups.

Foreign Christian groups are defined as either governments under the influence of Christianity that are outside of the countries in question, or private Christian Churches, or Christian organizations that are based outside of the countries in question.

Domestic groups will be defined as governments or organizations within the countries in question.

\section{ORGANIZATION OF THE DISSERTATION}

As stated, the question this dissertation is trying to answer is "do foreign Christian groups have more success influencing policy on homosexuality and abortion in countries with lower state capacity than they do in ones with higher state capacity"? This dissertation demonstrates that the answer is "yes" in two ways. First, it provides a quantitative analysis showing that less functional developing countries tend to have more 
restrictive policies on gay rights than do less functional states. Second, it provides a qualitative analysis that includes one developing country with higher state capacity and one developing country lower state capacity from each of the two developing areas under study: Latin America and Sub-Saharan Africa. For each of the countries under study, I describe how foreign Christian groups attempt to influence policy and how factors of state capacity impact on the success or failure of these outside groups' attempts.

Between the introduction and conclusion, there are four main chapters to this dissertation. The first is a literature review, which discusses relevant literature regarding important aspects of this dissertation. The second is a methodology chapter, which encompasses the quantitative analysis and lays out the parameters used in the qualitative portion of this study. The third chapter is the case-study examination for Africa, which includes sections on South Africa and Uganda. The fourth is the case-study examination for Latin America, which includes sections on Argentina and Guatemala.

\section{SUMMARY OF ANALYSIS}

In general, this dissertation will cover countries from the developing world, once known as the Third World. In particular it will focus on Christian groups attempting to penetrate countries whose populations are primarily Christian in Sub Saharan, nonIslamic Africa and Latin America. These two areas are examined because they are open to Christianity in a way that other parts of the Developing World are not, as I discuss in greater depth in the methodology section. Thus, the guidelines for countries under study are that they are Sub-Saharan African or Latin American. From these there will be one minor exception. The study does not include the Seychelles, which is genuinely unrepresentative of Africa as a continent due to its small size, island status, and its large French and Asian population mix so it has been dummied out of the model.

I postulate that policies of non-Christian countries can be similar to those where successful foreign Christian effort has occurred but that in Islamic or Communist countries the policies are not due to foreign Christian effort in the country but with indigenous non-Christian based cultural attitudes being reflected in them. 

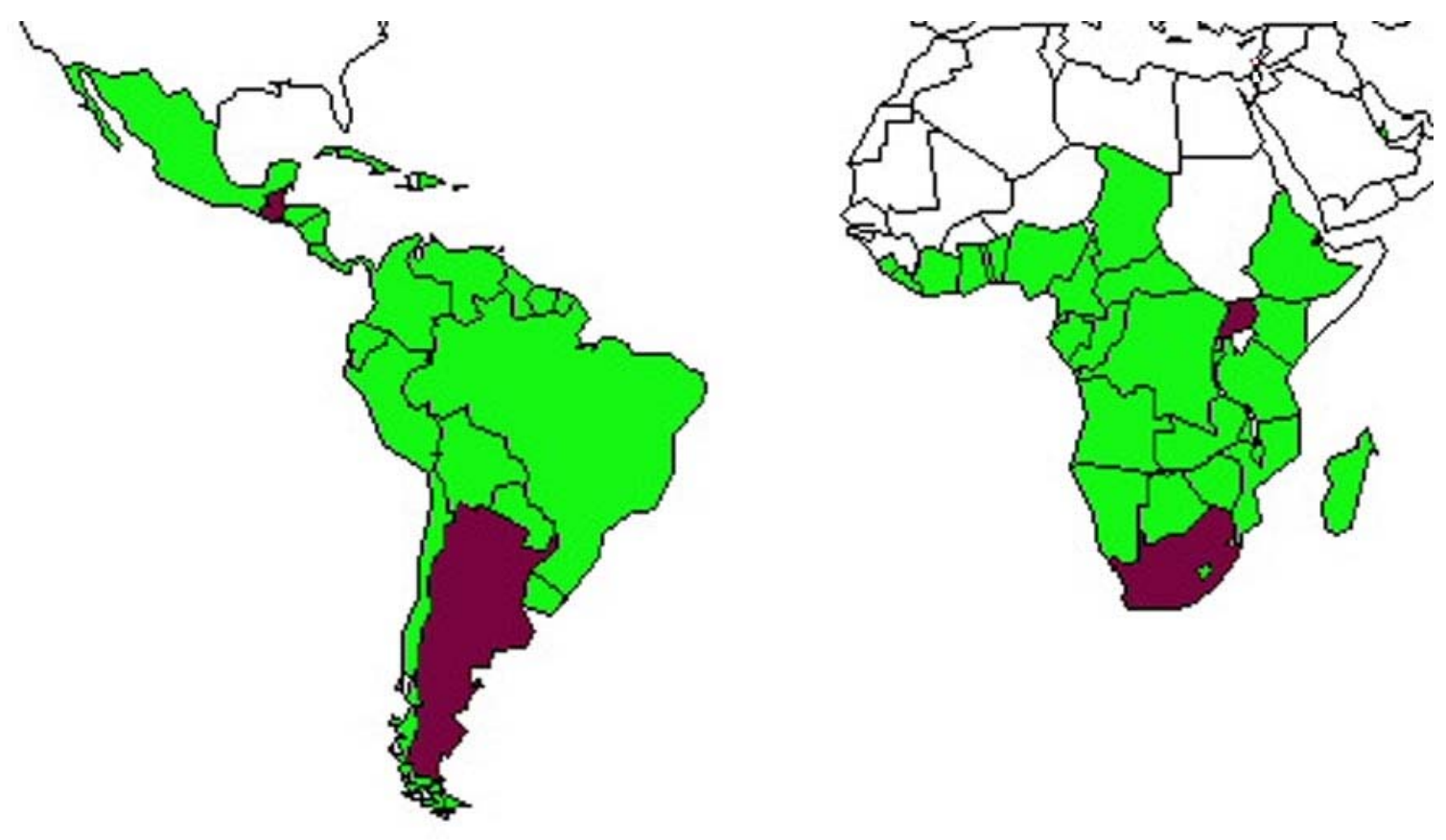

\section{$\underline{\text { Key }}$}

White: Not Under Study

Green: General Area Under Study

Scarlet: Case Study Country

Figure 2 - Map of Areas Under Study

Thus this paper will analyze the data as it was collected and will demonstrate that the theories predicted are supported by the statistical analysis. It will look at the attempted foreign Christian effort as of 2000, and the Human Development Index as of 1995, 2000, and 2005 in order to give results from a wide range of years and demonstrate similar results from a wide range of years. It will then look at Abortion and Homosexual rights legislation as of $1997 / 98$ and $2007 / 8$. It will thus focus on a wide range of countries from throughout the developing world, as described below.

The quantitative portion of this study demonstrates that there is measurable basis for the qualitative analysis that will come later. As this is a correlation study with a simple correlation statistic, there would be no specific dependent/independent variable in the quantitative section. The data will be pre-existing and obtained from sources which contain the relevant information. 


\begin{abstract}
APPLICABILITY FOR THIS STUDY
Looking at this project as a whole, the niche this fits into is an expansion of our knowledge on international influence, and the transnational political activities of nongovernmental organizations and non-state actors. This study deals with how nongovernmental politically active groups influence, fight, or interact with host countries. This is important in a world which is becoming smaller and thus countries are interacting more than ever before. It is also important in that gives insight into how NGO's and nongovernmental actors affect public policy in the international arena. It demonstrates that social attributes of the host country such as its state capacity have an impact on how well foreign messages, in the case of this study foreign Christian messages, are received and acted upon in the Developing world.
\end{abstract}




\section{CHAPTER 2: LITERATURE REVIEW}

What follows is a discussion of the relevant literature that this work will fold into. This literature review will begin with a discussion of state capacity. This is critical in this work in that a state's capacity is an important indicator of how well the state is doing and thus is critical in the discussion of states that are having problems and states that are not. States with a high state capacity are thought in this work to be less open to foreign Christian effort while those with lower state capacity are theorized to be more open to this effort. Thus state capacity is important in this work.

After the discussion of State capacity I will go into a discussion of nongovernmental organizations. These are groups that have global influence. Most of the discussion of NGOs in this literature review section will revolve around helping NGOs and multi-national corporations. This work will focus on religious NGOs specifically foreign Christian ones and their impact on developing world domestic policy. It is important, however, to have grounding in the NGO literature.

I will then move onto religious groups working abroad. This is important due to the fact it gives some insight as to religious groups and their activities in other countries throughout history and today. This gives important background to this study which involves foreign Christian groups.

After this I will discuss social movement affecting public policy. I do this to emphasize that social movements can and do affect public policy. Through their activities society's values and policy can and do change. This is vital to this work in that I focus on social movements affecting public policy.

Following the leadership portion of the literature review the discussion will focus on religiosity and human development. This is important to discuss due to the fact that there is more religiosity the less developed a country is. As a result, it fits that countries with less human development would be more open to foreign Christian effort than those which have a higher level of human development, as they are already more religious.

\section{STATE CAPACITY}

The following section on state capacity will start with defining characteristics of state capacity. It will then delve into specific types of state capacity. It will then close 
with a brief discussion about what elements of state capacity are important with regards to this work.

As stated above, state capacity is critical with regards to this dissertation as it is a major factor in determining how a country and its government are doing with regards to the lives of its people. Evans et. al. (1985) discusses it in regards to a country's ability for a government to have the ability to affect different aspects of national life such as the economy and providing for its people's needs. Cardenas (2010) argues that state capacity involves the ability of the state to provide public goods and support the economy within a sound legal frame work." (Cardenas, 1) He states that there are four main areas of state capacity to be focused on. These are military, bureaucratic and administrative capacity, fiscal capacity, and the fourth is the "quality and coherence of political institutions. (Cardenas, 3) In terms of African development it used to be thought that merely investing money in Africa as well as giving them engineering resources would be enough to boost African development. This was later rejected and development proponents emphasized other factors such as weakness in much of the political, institutional, and social institutions of a country. It is argued that Africa has weaknesses in these institutions. (Levy, Kpundeh, 1)

Levy points to the interplay of four broad categories as being important to state capacity. These are the bureaucracy, the economy, political interests, and formal political institutions. (Levy, Kpundeh, 3) In Africa there has been a decline in bureaucracy, which affected the economy of the state and this led to a lack of sound policy making and service delivery. This lack of policy making and service delivery was combined with neo-patrimonial rule. In this system allies of the state were benefited to the determent of growth, sensible regulation, and good public services. (Levy, Kpundeh, 5) State capacity generally involves a state's ability to perform its functions in a wide range of areas. Included in this is the capacity "of how states do (and should) affect domestic economic life" (Evans, 358) with regards to international and domestic issues such as the economy. (Evans, 358). Evans argues that different countries not only have differing state capacities in general, but also in specific areas, and the different abilities to meet important tasks. He points to the fact that it is important for the state to have a role in industrialization and economic transformation. Some states have more of an ability to 
affect some areas over others. Governments have different organizational structures that enable them to intervene and be active in differing parts of the life of the countries in question. It is this difference in state capacity that is important to this study. Countries have differing state capacities and, therefore, differing needs and abilities in influencing the societies in those countries; leaving some states more open to influence from outside. This work will focus on states with more limited state capacity as being more open to foreign Christian effort, because while states with more state capacity are more difficult to influence for such groups. (Evans, 351-366)

According to Organski and Kugler (1980) national capability involves the number of workers and their production, but also "the effectiveness of the political system in extracting, pooling, and allocating individual contributions for use in the pursuit of national goals." (Organski, Kugler, 85) This fits in well with the concept of how successful counties are with regards to this dissertation.

According to Almond and Powell (1966) there are several capacities that a state must possess. The first of these is the extractive capacity which is the ability of the state to glean resources from the area under its nominal control. This involves what the society can, and is willing, to furnish the government and under what circumstances.

There is also the regulative capability. This capacity is what control over the behavior of the states' people that the state has. In other words, how much does the state interfere with and dominate the actions of the people who live in the state? This regulative capacity includes such things as protecting the average citizen from monopoly control, enforcing contracts such as marriage, as well as the responsibility of parents, and preventing actions such as murder. In other circumstances, the state might attempt to control even more of the behavior of its people. This depends on what kind of state it is. Importantly for this work, if the regulation of the state in question is open then regulations that are opposed by some people can be protested and fought. (Almond and Powell, 196/197)

States should also possess distributive capability; this capability is demonstrated by how the government distributes resources such as goods and status. The political systems in question often do distribute these benefits to groups and people within their society. Distributive capacity includes the critical ability or lack thereof to meet the 
needs of the people and the groups within the societies in question. These distributions can include financial expenditure for such things as basic life's necessities such as social welfare, or expenditure for things such as sewage, police, or health. (Almond and Powell, 198)

Further, the state has symbolic capacity. This capacity involves the state's ability to use symbols to effect societal action. Such symbols include displays of the flag, ceremonies, visits from elites such as royalty, or statements of values by those who are elites in society. It must be noted that outputs of symbolism should not be conflated with the capability of the symbols. As Almond and Powell point out, if the royalty are hated their symbolism will be less effective. Thus "symbolic measures may be transmitted but not received." (Almond and Powell, 199/120)

There is also the concept of responsive capability which differs from the previous types in that those types are outputs from the state. Responsive capability is the dichotomy of both the outputs and the inputs of the state. Every system is responsive to a certain degree but some are more so than others. It must be asked whom the system is responsive to, what areas does the system respond, and how a system manages to maintain the response? In totalitarian governments the responses is often dependent on the desire of the leader and the elite, while in a system with more interest group or political party activity, the elites are often sensitive in calculating their responses to those groups. (Almond/Powell, 201)

With regards to domestic and international capabilities I must look at the dichotomy between the interaction of the political system domestically and the performance internationally. Thus I can look at foreign trade, tourists, and the amount a foreign force can that can influence the political system. Examples include puppet regimes and foreign aid. (Almond and Powell, 203/204)

How elites react to inputs both domestic and international is critical to the actions of state governments. Elites can repress, ignore, or accommodate. Further, states have differing capabilities. States without the capability of adequately extracting and regulating will have problems distributing resources to its people. (Almond and Powell, 207/208) 
According to Cardenas, state capacity is weakened when there is a high concentration of societal resources such as political and economic power. He argues that an investment in the future is needed even though it will lead to more immediate sacrifices. When one group has most of the resources in a society they are less willing to make that sacrifice for the general well being. (Cardenas, 2)

War can also have an impact on state capacity. According to Besley and Persson (2008) differing types of wars have a different effect on state capacity. A civil war is more likely to harm a country's state capacity then a foreign war. This is due to the fact that in a foreign war the society is more unified while during a civil war it is divided amongst its various parts and against itself. Both Guatemala and Uganda have suffered very serious civil wars fairly recently. The new South Africa and Argentina have not had to go through civil wars recently.

\section{NON-GOVERNMENTAL ORGANIZATIONS}

Non-governmental organizations also play a role in this work. It is therefore important to give a brief account of such organizations. This section discusses NGOs in general in order to give background literature on such organizations and the role they play in policymaking. Most of the Christian groups that are attempting to influence the policies of the countries in question fall into the category of non-governmental organizations, although there will be some discussion of the role that governments play. The following section on NGOs will start with what NGOs are and what they do. It will then discuss funding and interactions with host governments.

Non-governmental organizations, or NGOs, are not part of the government of a state. They are set up to perform certain functions, and play a role in pursuing certain objectives. These functions and objectives vary from NGO to NGO. Relevant to this study, there are many that have as a goal the desire to help those in Less Developed Countries develop. These include such organizations as Doctors Without Borders and other charity organizations. Others work towards an end to conflicts. The types of NGO that I will be focusing on in this paper are religious organizations whose goals are to convert people to their belief structure and influence the governments of the targeted countries. Governments and NGO's can often work together to achieve an objective. 
NGOs are very diverse when it comes to their structure, size, and goals. (Commins, 25/Crocker et. al. 48)

New Medievalists argue that Non-Governmental Organizations are on the rise as some states are waning. They are a group that, as argued by Hedley Bull in the Anarchical Society, believes national borders are becoming less important and that there are now many differing foci of influence in societies around that world. (Bull, 245-246)

Non-governmental organizations are important in terms of international regulatory agencies. They have also become important in such areas as the environment. The number of NGO's has increased to approximately 30,000 at the turn of the century with most but not all being based in the developed world. These organizations are able to communicate and work with each other and they are increasingly doing so. They are successful in influencing the policies of domestic governments. They also help in the development of a civil society for the world as a whole. (Gilpin, 391-396) Nel et. al. (2001) finds that in community based NGO's local skills in the community are important in determining success. Local emphasis is thus important. (Nel et. al., 11) As will be seen, foreign Christian groups work with local actors in order to implement their policies.

Many developing states have their state capacity reduced due to climate problems. There are many NGOs working hard in this area to reduce the impact of climate change. The NGO community has evolved as the salience of climate change issues has grown. (Raustiala, 99) The original groups are now being joined by trade and business organizations. Environmental NGOs play an important role and also "include many groups with a strong development and/or poverty focus." (Raustiala, 100) Religious organizations are also playing a role in the environment. Many see a moral issue on a large scale. They have concern for those in poverty who are affected as well as beliefs based on creation which should be well managed by humanity. (Raustiala, 103)

NGOs aiming to help a society fall into roughly four categories: 1 . They provide humanitarian help to those in crisis. 2. They promote economic and social development where poverty is present, 3. They monitor human rights. 4. Finally, they promote peace by helping provide methods of non-violent problem solving such as, negotiation techniques and non-violence. (Anderson, 1996, 344) 
NGOs can make an impact in helping people of the less developed world. They encounter situations that are complex, helping those in need such as Cambodian refugees who are resented by those who stayed behind and working to ease the interplay between assisting those who need help and the forces that fuel the conflict that required the assistance of the NGO's to start with. (Anderson, 1996, 343-344)

NGOs receive their funds from donations that come from either the public sector or the private. Thus, they are dependent on donors for the money that they use to operate. This fundraising is a constraint faced by NGOs. They often use examples of desperate situations to demonstrate need to donors. There is a thin line for many organizations that is drawn between demonstrating poverty and actually encouraging donors to help. (Commins, 25)

Thus, although many NGOs are united by a shared desire to improve living conditions for the people of the world, they are diverse. Some will work with institutions while others will attempt to create grass-roots movements who see bureaucracies as harmful to their goals. (Aall, 435) Further, many of the NGO's are flexible and allow the targeted groups to help in making important decisions for the community that is targeted by the NGO in question. (Commins, 26)

In fact, in some parts of the developing world, it is the case that non-state actors such as NGOs like Doctors Without Boarders, the Christian Children's Fund, and the Afghan Women and Children's Development Organization are playing a leading role in development. This is due to the fact that in many of the developing countries there is forced retrenchment in their economies. In other words, they are required due to budgetary restraints, to actually pare back the amount of money that they are spending on development. Due to this, it is the case in the developing world that NGO's, who sometimes work for opposite or contrary things to each other in the same state, can actually play a larger role in development than the states themselves. (Rapley, 2002, 152153) Still NGO's often can not make up for the failure of states and even with NGO presence "there is no automatic shift toward stronger societies as states weaken." (Rapley, 176)

Christian NGO's have joined the fight against homosexuality and abortion. Groups such as the Women for Faith and Family or WFF argued that "lobbying in 
obscure UN forums and grafting homosexual rights onto existing treaties are nothing more than maneuvers[s] to bypass ratification and avoid ... confrontations." (Bob, 61) This was in response to gay groups and their allies who are attempting to use human rights grounds to gain rights that they did not otherwise have. (Bob, 61) In the 2004 Doha International Conference for the Family, American Christian Groups such as Bingham Young's World Family Policy Center, the Family Research Council, and the Catholic Family and Human Rights Institute or C-FAM helped craft a resolution to state that only men and women should be allowed to marry and that the [heterosexual] family is the "natural and fundamental group unit of society." (Bob, 55) Certain Christian Groups are going beyond relief and missionary work, "they leap boarders and institutions to help fellow believers, and they run razor sharp campaigns to gash secular foes." (Bob 38) NGOs have diverse agendas and these groups have a social agenda not just one of assistance and development.

NGOs are quickly becoming powerful players in various aspects of international relations. (Aall, 1996) The foreign Christian groups focused on are NGOs. They play a role which does not have much to do with helping to solve conflict or providing aid to the needy, although they do these to an extent. These groups are NGOs whose desire is to replicate their belief structure in other countries and alter the policies of targeted countries, not for human rights, but in fact to harm the human rights of those whom their belief structure opposes.

\section{RELIGIOUS GROUPS WORKING ABROAD}

Given that this work focuses on the influence of foreign Christian groups it is important to give some of the literature on missionary activity. There has been a great deal of this activity historically. There is also a great deal of foreign Christian activity in the modern era. The next section will discuss some examples of missionary activity as it pertains to early Latin America and then colonial Africa. It will then discuss some modern activity in Africa and Latin America.

Religious groups have worked abroad for centuries. The conversion of the Spanish Colonies in Latin America began in 1500. At this time a Franciscan Mission arrived in the Colony of Santo Domingo, now in the Dominican Republic. The Church went on to establish the Dioceses of Santo-Domingo and Puerto Rico. (Dussel, 47) As 
Hernan Cortez explored the mainland he was accompanied by a priest and friar who attempted to convert the indigenous people. Systematic attempts at conversion occurred with the arrival of priests from the Franciscan Order. (Dussel, 49)

Attempts to convert the Inca Empire occurred beginning approximately 1530. As missionaries penetrated the Inca Empire the Cross was raised over Plaza of Cuzco in 1533. The Pope created a Diocese of Cuzco and named Friar Vincente Valverdi to be the new Bishop who arrived in1538. (Dussel, 49) Catholicism then proceeded to spread and most of what is now Latin America became Catholic.

Africa too was the subject of missionary activity. As Europeans entered the continent in greater numbers missionaries also went to Africa. The missionaries saw themselves as bringing Christian Civilization to the people of Africa. Examples abound. One such example is the training of Tswana Women to do housework as did the women of the missionaries. The missionaries set up informal household training classes for the Tswana women dating to the early 1830's. According to the wife of one missionary "our chief work is to keep the husbands $u p$ from sinking down down (sic) gradually into the native style of living." (Mafela, 87) The goal was to mold the Africans household into the Western household. (Mafela, 87)

Activity was not limited to women however. Missionaries were set up throughout Africa. An example was a mission set up south of Lake Tanganyika in 1883, in an area now controlled by Zambia in the country of the Lungo People. This was followed in the next decades by missions to groups in the area such as the Niamkolo, Mporokoso, Mbereshi, and the Kambole as well as other African Peoples. (Carey, 2) Missionary activity continued well into the twentieth century. One missionary from Canada became so caught up in the struggle for Zambian independence that he was removed from the colony but was later nominated a "Hero of the Zambian Republic." (Carey, 5)

Missionary groups emanated not just from the great powers but also from lesser European States. The Christianization of the Krobo in what is now Ghana started in 1836, with the activities of the Evangelical Missionary Society of Basel often known as the Basel Mission. This organization set about attempting to alter the pagan rituals of the people that the missionaries felt over sexualized the Krobo people. (Steegstra, 201) The 
operation was a success and there are now Christianized Krobo people who reject the old customs of their people in preference to the Christian ones. (Steegstra, 201)

Modern Christian groups are also active. Kapya Kaoma, a Zambian cleric, has written about the infiltration in Africa by foreign Christian groups. He argues that these groups are exporting the culture wars of the United States as the center of Christianity shifts from the Earth's North to its South. (Kaoma, 3) These groups are attempting to influence policy in the Developing World in an anti-gay fashion. They are using tools such as arguments about Western cultural imperialism to argue their points (Kaoma, 2009) and "have successfully recruited a significant number of prominent African religious leaders." (Kaoma, 3)

Efforts have also been made by foreign Christian groups to reach other parts of the Developing World. An example is Guatemala. This country has been and still is influence by the Christian Right. Missionaries sent to Guatemala in the 1970's converted General Efrain Rios Montt (Diamond, 1989, 164) to the Verbo Church. (Garrard-Burnett, 139) He even became a leader of the church. (Diamond, 1989, 164) General Montt would become President of Guatemala and be celebrated by conservatives from the United States (Diamond, 1989, 164) According to Mott in a speech "Here the one in charge is Jesus Christ." (Stoll, 2) Language too is important. Although it acquires new shades of meaning in Guatemala much of the Protestant language in that country comes from the United States. (Stoll, 4)

\section{SOCIAL MOVEMENTS AFFECTING PUBLIC POLICY}

Social Movements have always affected public policy. This is critical to the understanding of the movements that are discussed in this work (foreign Christian Groups.) Although a complete telling of all of the examples of social movements affecting public policy is beyond the scope of this work some discussion is warranted. The following section will describe some of the literature that involves social movements, particularly religious, that have affected social and political policies in countries of the world. It will discuss Al-Qaeda and their effect of the policies of the United States and also Christian Churches and those churches effect on Europe a continent that went on to spread its beliefs throughout the World. 
Terrorist social movements have had a global effect. On September 11, 2001 Al'Qaeda, a movement that represents a strict form of Islam, a form that was also antiWestern in general and anti-United States in particular, attacked New York and Washington DC. According to Barber (2001) the World's seemingly unstoppable movement to a post- modern, secularist and free market materialist based world received a major blow. After this attack, the outcome of the struggle of "Jihad vs. McWorld" as Barber refers to it now seems much less clear. (Barber XI)

The attack shifted social policy in the United States. There were a host of policy initiatives that were put in place as a result of this attack. Some of these initiatives had the effect of reducing the civil liberties of the people of the United States. The Patriot Act was one such measure. (Vlcek, 21/22)

After the attacks on New York and Washington DC, 2/3 of Americans stated they were willing to give up civil liberties in order to thwart terrorism. (Rackow, 1651) The Patriot Act allowed the United States' government more leeway in areas of surveillance in areas that are not necessarily vital for the battle against terrorism. These include the monitoring of telephone conversations, without probable cause, of those suspected of committing a domestic criminal act. (Rackow, 1653) This was a boon to those in the United States who are more "law and order" oriented. They had failed earlier to get many of the same provisions enacted into law but now due to the Al'Qaeda attack they and those in fear of terror were able to unite and get the reduction of civil liberties that came with the Patriot Act passed. (Rackow, 1694) Thus the international social movement of al-Qaeda had an influence on the policy of the United States, as stated; the "law and order" American groups were able to get what they wanted out of policy as a result of the attack.

Social movements based on religion are important and have led to changes in societies. Christianity started as a social movement in the Roman Empire and went on to become the major religion of the West. This control from Rome led to a differing political development in the Western World as opposed to other parts of the world such as East Asia. "The existence of a separate religious authority accustomed rulers to the idea that they were not the ultimate source of law." (Fukuyama, 273) Christianity became a social movement outside of the state structure of Europe and provided an 
alternate power point to the individual monarchs in Europe. A Christian King was therefore not above the law in the sense that a Chinese Emperor was as that Emperor was the source of law as opposed to a religious God. (Fukuyama, 273) Fukuyama argues that religious law that came from the Church in the middle ages had the effect of institutionalizing the law of Europe. (Fukuyama, 273) Thus, the social movement that started out as a splinter group in the Roman Empire, became its state religion, survived the empire's collapse and was critical in influencing the development of European law and government.

According to R. H. Tawney, the rise of Capitalism in the West is due to association with the social movement of Protestantism. (Tawney, 2000) Until the middle of the $16^{\text {th }}$ Century secular law reflected Catholic cannon law in that usury was not to be allowed; even in the important financial center of Florence, usury was punished by the secular authorities. (Tawney, 37) The switch to a financial system that was more permissive of interest charging was the social movement of Protestantism. (Tawney 215216) This was the case in England (later the United Kingdom) where there was a changeover from Catholicism to Protestantism after Henry VIII split from Rome. Tawney argues that the more important change occurred with the advent of Puritanism in England. "Puritanism, not the Tudor secession from Rome, was the true English Reformation, and it was from its struggle against the old order that England which is unmistakably modern emerges." (Tawney, 198) Although there was still condemnation of the practice of charging interest in some Protestant circles it became more permissible. (Tawney 215/216) Tawney points out that Calvinism was, in its English type, the forbear of capitalism. (Tawney, 212) This was partially due to the fact that Calvinism allowed interest to be charged. (Tawney, 215-217) Interest is critical in the capitalist world that we know today and thus a critical change brought about by a social movement.

Social movements are an important aspect of global politics. They have the ability to alter pre-existing political structures in radical new ways. Social movements are largely responsible for the capitalist world that many in the West know today and also the movements such as Al'Qaeda who are fighting to overthrow this system. 


\section{RELIGIOSITY AND HUMAN DEVELOPMENT}

The following section will lay out some of the foundations for the connection between religiosity and human development as it stands in the literature. Further, this section will go on to describe how religiosity affects the type of thinking a person has. In other words, how important faith is as opposed to non-theological or secular evidence in the determination of political opinion, as well as an absolutist point of view verses a more fluid one. In other words it is important to determining whether views are set in stone or more malleable. It will then discuss some of the psychological impacts of religion on the people involved and discuss some of the relevant literature regarding the types of countries where homosexuality is accepted verses not accepted.

Central to this research is an investigation of whether states featuring lower levels of state capacity have both societies and governments that emphasize religious priorities. Reese argues that people living in countries with a lower standard of living are more likely to have strongly held faiths as opposed to those countries where people tend to have a higher standard of living. (Rees, 2009) In Rees' article he mentions that Thorleif Peterson. In Peterson's book The Relation between Religion and Politics in the Contemporary Western World, states that when a country has developed a more industrialized culture, the prospect of activities that are not religious become greater, leading to higher opportunity costs for religious activity. (Rees, 2009, 2) Further, in Rees' paper he points out that Norris and Inglehart claim in their research that inequality of income lead to an increase in the amount of religiosity in a country. (Rees, 2009, 3) States with lower state capacity often have great income inequality. They are therefore societies that could be more receptive to foreign Christian influence. People in poorer states have insecurity and stress due to the difficulty they have providing enough to eat for their families. On top of this they often receive poor medical care that is dependent on foreign donors who can cut off funding at a moments notice. People might react with more religiosity when they are feeling insecure due to the fact that an inability to control one's environment; and people who are under a lot of stress have a psychological reaction that leads to "superstitious or magical thinking." (Rees, 13 2009, and Whitson et. al. 2008,115) The needs that people have at a given moment can both bias and shape how the world is perceived world around us. (Whitson et. al. 2008, 115) 
According to Peter Berger in his book the De-secularization of the World: Resurgent Religion and World, (1999) many of the "religious movements are linked to non-religious forces." (Berger, 1999, 12) He argues that as countries become economically better off, certain religious movements will have a more difficult time remaining unchanged "in the face of modernity." (Berger, 1999, 12) This is important due to the fact that countries having lower state capacity often have populations with lower economic status. If countries that are better off are changing their views to challenge religious messages this is evidence that foreign Christian groups would have a more fertile field for their ideas in a country with lower state capacity. In other words, the societies with lower state capacity would be ones in which modernity has not forced some changes in religious movements. Gruber and Hungerman argue that when nonreligious factors begin to have more sway in society, the opportunity costs for religious activity goes up and religious activity goes down. (Gruber/Hungerman, 2008). The Pew Research Center has done a study of religiosity that shows that there is a correlation between income and religiosity. It can be seen that as wealth goes up religiosity goes down. Thus, in countries where there is more insecurity, it is likely that there would be found more religiosity. 


\section{Sampled Countries - Wealth vs. Religiosity}

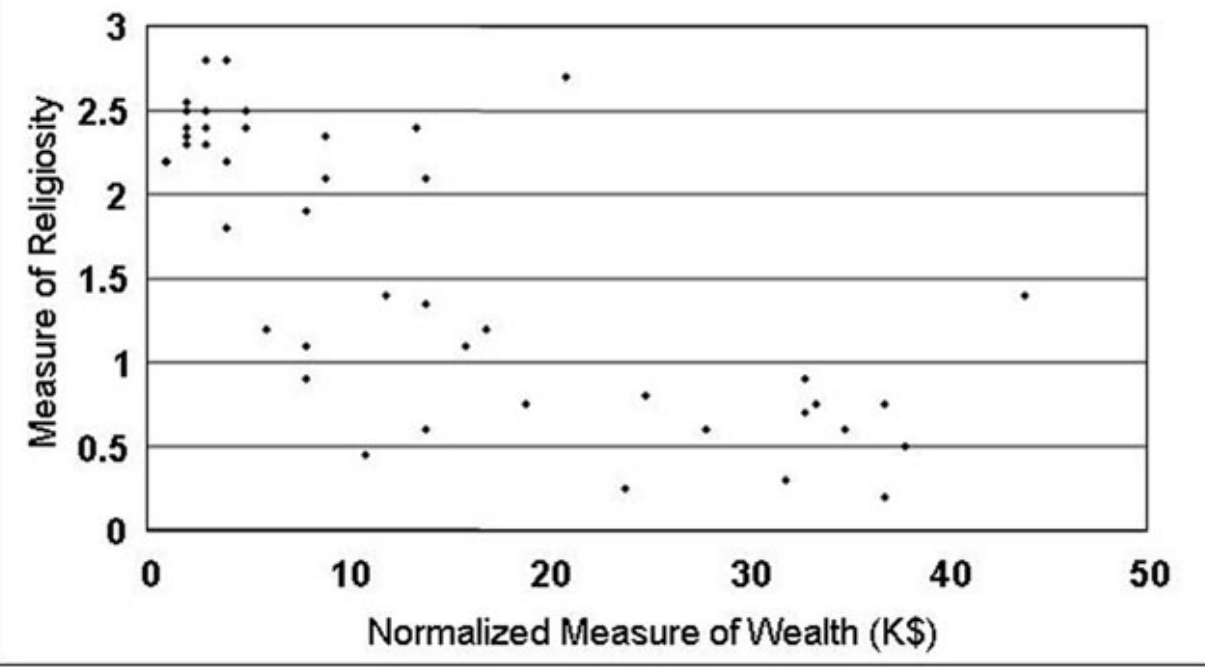

- Pew Research Center

- http://pewglobal.org/2007/10/04/world-publics-welcome-globaltrade-but-not-immigration/

Figure 3 - Wealth and Religiosity

Development is often associated with a shift away from opinions that are absolutist on values and norms and become more based on tolerance. (Inglehart/ Baker, 2000, 19) Economic disintegration is likely to push society in the other direction. (Inglehart/ Baker, 2000, 49) Moreover, if one looks into the literature on leadership one sees that if a leader can give what one wants then he/she is more likely to be followed. "Reward power implies the ability of one individual to facilitate the attainment of desired outcomes." (Bass, 1981, 180) Religious leaders promise salvation through a "correct" way of living. It follows that one who lives in misery would be influenced by the idea of a better future existence, one that is promised by religious leaders. People often look to religion for hope and, when it is offered, as a way of salvation in a country with severe problems, religion gives hope and begins to lift people out of despair.

Jared Diamond postulates that "we may ignore a bad status quo because it is favored by some deeply held value to which we cling." (Diamond, J. 432) Thus, it seems that people will overlook problems if our values are sated. (Diamond, J. 432-33) In other words a bad situation is sometimes tolerated or ignored if a core belief is upheld. Some 
Christian groups such as those led by Pat Roberson, Scott Lively and Rick Warren, use anti-homosexual belief as a core belief. A policy of oppressing groups such as gays is overlooked as long as the people who are being conditioned to attack them hold a core belief such as a religious one as provided by the Bible. This is especially true when that is provided by the religious organization. Much of the developing world could fall into this category and hence be more open to foreign Christian effort by those Christian groups. People in the developing world often do not have access to health care, clean water, or enough food. Many are in situations where there is a great deal of violence that prevents them from earning a reasonable living for themselves and their families. They therefore live in a bad situation. Religion can be a bright spot for many in these types of situations. If their need to believe is at least sated then that is something positive (for them) that these people can hold onto. They will then be more willing to accept bad things happening to someone else as long as their own personal need for some kind of psychological relief from these bad situations is met.

This author theorizes that desperate people living in countries that can not provide or have difficulty providing for their basic requirements are more likely to be influenced by the ideas of the groups helping them. The "rule of reciprocation" is argued by Robert Cialdini $(1993,21)$. He states that when someone receives something from another, the recipient has a desire to reciprocate and do something for the person who gave them something. Thus, under the "rule of reciprocation" (Cialdini, 1993, 21), if people receive something, they would be much more likely to say yes to the giver, even when they would otherwise have said no. The foreign Christian groups promise or give the gift of salvation, a better existence, as well as concrete material goods to those whom they convert, at least in the minds of the people converted. Thus, psychologically, they have done a great deal for the people whom they have converted. Further, it is often the case that aid is tied to the conversion of those needing the aid.

According to Katherine Marshall, a senior fellow at Georgetown's Berkley Center for Religion, Peace, and World Affairs, "aid conversion" is the linking of aid to religious beliefs. This includes the receipt of a religious message in exchange for aid all the way to aid being dependent on conversion to the faith of the aid giver. (Marshall, WashingtonPost.com) This is critical in that it is a major way a foreign Christian group 
can influence the people in a target country. They can control life-sustaining resources and thus become an actor who must be listened to and treated in a deferential way. The suppliers of this aid can insist on subservient behavior by those receiving the material or spiritual aid.

Moreover, according to noted social psychologist Elliot Aronson, those who receive primarily a message based on emotion tend to be swayed more easily then a message based on a logical argument. (Aronson, 1999, 84) Further, if one looks at the work The Political Brain by Drew Westen (2007) it can be seen that emotions play a great role in determining political opinions. Westen points out with regards to the civil rights movement in the United States; that plays to logic had less of an effect than plays to emotion. This was an example of an emotional appeal overriding strict rationality for a good cause; it can also be used for bad ones. In the fight over gay rights in the United States much of the attack on homosexuals is couched in terms of bestiality, snuff films, and pedophilia. (Westen, 2007, 394) None of these claims is backed up by science but they play to people's emotions. Thus, if both of the above factors are combined it is likely that religion, which is often emotional and less often scientific, would more easily gain converts in a society with a message that was based on emotions.

People will act when they see the possibility of a better future that is being denied them. (Aronson, 1999, 276-277) The pastors or missionaries often discuss a better life (or afterlife) that the people in the developing countries can have by joining and staying with Christ. They provide some sort of hope in an otherwise difficult living situation. Homosexuals, Feminists, and pro-choice activists are often portrayed as acting against God and the life the country could have as followers of God. According to Donelson R. Forsyth, (1999) people are more likely to join a group if they suffer from relative deprivation. (Forsyth, 455) This is more likely demonstrated in the concept of fraternal deprivation where one sees one's own group as downtrodden as opposed to egoistic deprivation where the individual is deprived. (Forsyth, 1999, 455-456) In countries with lower state capacity people often suffer from deprivation of both kinds and therefore would be more open to the Christian message.

Added to the above, in a country with lower state capacity there are not many organizations that have the resources to successfully fight against this form of 
indoctrination. People are often concerned with physiological needs as opposed to needs of esteem such as approval as put forth in Abraham Maslow's hierarchy of needs. (Gleitman, 1991, 733) So people in countries with lower state capacities would be more open to messages of a religious nature combined with aid, and be more prone to be converted to the beliefs of the foreign Christian groups that are attempting to penetrate their country. These efforts will be described later in this document. These issues of deprivation illustrate that domestic factors contribute to the successful incursion of outside religious groups in the targeted societies. As they are focusing on basic needs there is less time devoted to the more social ideals of equality and freedom.

It is demonstrable, that in countries with higher levels of state capacity there has been a radical shift in the rights for Homosexual people. Homosexuality was once looked down upon in the Netherlands, a country with high state capacity which boasted the highest favorability rating. The ten countries that have the lowest disapproval ratings of Homosexuals are all in better off European or North American countries. (Inglehart and Welzel, 2005, 40,41) According to Inglehart and Welzel, (2005): "Socioeconomic development brings systematic changes in political, social, and cultural life." (Inglehart and Welzel, 2005, 46) 


\section{CHAPTER 3: METHODOLOGY}

\section{OVERVIEW}

This dissertation intends to demonstrate that developing countries with lower state capacity are more open to foreign Christian effort than those with higher state capacity. This is demonstrated in two ways. The first is composed of several quantitative correlations. As correlations, they show a correlation between the Human Development Index and the level of gay rights though not abortion. Secondly, I establish that state capacity has an impact on the success of foreign Christian effort by a series of case studies of various countries.

One would not expect all developing countries to be equally penetrable by Christian groups. Those with strong Islamic backgrounds would be unlikely to be open to much foreign Christian effort as there is already a strong religion that occupies that space for religion in Society. Sub-Saharan Africa and Latin America have been more successfully Christianized by Western missionaries and elites during colonial periods in a way that did not occur in much of the Islamic or Buddhist Worlds. Further, closed atheistic countries, such as North Korea, would not be open to foreign Christian effort due to strict atheistic societal controls over the thoughts of the people. Thus, it is important to state that the study only covers certain parts of the developing world specifically Sub Saharan Africa and Latin America. These areas are politically open to foreign Christian effort in that there is not another dominant cultural ideology involved.

\section{QUANTITATIVE METHODOLOGY AND RESULTS}

In general, this dissertation covers countries from the developing world or what was once known as the Third World. In particular it focuses on right-wing Christian groups attempting to penetrate countries whose populations are primarily Christian in Sub-Saharan non-Islamic Africa and Latin America. The guidelines for countries under study are that they be Sub-Saharan African or Latin American. There is one minor exception. It does not include the Seychelles, which, as said above, is genuinely unrepresentative of Africa as a continent due to its small size, island status, and its large French and Asian population mix. 
I look at the attempted foreign Christian effort, as of 2000, by the number of foreign missionaries located in a given country as published in World Christian Trends. I look at the Human Development Index as measured on a 0-1 scale from the Human Development Index published by the United Nations for the years 1995, 2000 and 2005. I then look at Abortion and Homosexual rights legislation as of 1997/98 and 2007/8. This data is also gathered from United Nations reports for abortion and International Lesbian and Gay Association. World Christian Trends is a book that looks at statistics of Christianity on a global scale. The Human Development Index looks at factors of human development such as life expectancy, education, standard of living and literacy. (HumanDevelopmentIndex.net) The International Lesbian and Gay Association is an organization that compiles statistics and facts regarding the status of Gays around the globe. It thus focuses on a wide range of countries from throughout the developing world, as described below.

The quantitative analysis in this study provides independent evidence to complement the qualitative analysis that will come later. As a correlation study with simple correlation statistics, the variables discussed are not technically described as dependent/independent variables in the quantitative section. The data is pre-existing and obtained from the sources listed above which contain the relevant information. The quantitative portion of this paper employs measurements of the following several variables with regard to countries of the developing world in order to establish correlations

Policy is the primary measure that is correlated with the HDI. HDI is the measure that characterizes a state's capacity with regards to this document. The measures of policy will be a measure of abortion rights, and the rights of homosexuals. Abortion is measured on a scale of values with: 1) legal without restriction, 2) legal on health grounds, 3) legal to save the life of the mother 4) illegal. This is a scale of my design that ranges from least restrictive to most restrictive. Homosexual rights are measured on a scale of: 1) homosexual marriage legal, 2) domestic partnership, 3) civil rights protections, 4) legal, 5) illegal, 6) illegal with the death penalty. This is also a scale of my design from least restrictive to most restrictive. As far as criminality goes, illegality would be more restrictive than any form of legality or protection while the death penalty 
would be the most restrictive for obvious reasons. These are measures of policy areas which are very important to many Christian groups. Christian policies would be more limiting, in other words are closer to the higher end of the scale, as they are in support of more preventive polices when it comes to issues of morality, and not the more liberal lower end of the scale. The data on policy is drawn from International Lesbian and Gay Global Reports which, as stated above, are reports drawn from the International Gay and Lesbian Association which gathers information as to the rights of gays around the world and the United Nations which publishes abortion rights statistics. (ILGA Reports, 1998, 1999, 2007, 2009, 2010, United Nations Abortion Reports, 1999, 2007) Thus the variables are measured as follows. The Human Development Index is on a 0-1 scale with, 1 a higher human development score and 0 a lower human development score. Thus the data points are different decimal numbers between one and zero, as taken from the United Nations Human Development Report. Foreign Christian effort is a measure of number of foreign missionaries per million as drawn from World Christian Trends. Policy is demonstrated through gay rights and abortion rights as per the scale above. I look at the foreign Christian effort as of 2000, and the level of functioning in the Human Development Index as of 1995, 2000, and 2005. I then look at abortion and homosexual rights legislation as of 1997/98 and 2007/8. Gay rights data is drawn from International Lesbian and Gay Reports. Abortion data is drawn from United Nations documents. Policy will be as described above.

As said above a basic rule is that the quantitative section covers countries whose populations are primarily Christian in Sub-Saharan non Islamic Africa and Latin America. As said above, it does not include the Seychelles, which is unrepresentative of Africa and has been dummied out.

The correlation study and the results are as follows. 
1995

Gay Rights 1997/1998

Human Development Index Significance

Gay Rights 2007/2008

$-.4576^{* *}$

.0006

$-.5399 * *$

.0000

Abortion 1997/1998

.0951

.5024

Abortion 2007

.0925

.5143

Table 1 - 1995 Correlation Between Human Development Index and Policy Area 2000

Gay Rights 1997/1998

Human Development Index Significance

Gay Rights 2007/2008

$-.4320 * *$

.0012

$-.5126^{* *}$

.0001

Abortion 1997/1998

.0715

.6109

Abortion 2007

.1129

.4208

Table 2 - 2000 Correlation Between Human Development Index and Policy Area

2005

Gay Rights 1997/1998

Gay Rights 2007/2008

Abortion 1997/1998

Abortion 2007
Human Development Index Significance

$-.4209 * *$

$-.5054 * * \quad .0001$

$.0838 \quad .5507$

.1379

Table 3 - 2005 Correlation Between Human Development Index and Policy Area

This analysis shows that the worse a country scores on the HDI the more likely it is that the country will have anti-homosexual policies in all three years measured. Three years over the course of decade centered on the year 2000 the turn of the millennium and the year from which data regarding missionary activity, such as that described below, was available, were measured to ensure a consistent set of results which were achieved. . That can not be said for abortion where the results were not statistically significant.

Below, I display a second analysis since there may be some concern that the correlation between the HDI and policy might be do to increased foreign Christian effort into the less functional developing countries. To deal with this I introduce evidence below that shows in reality there is more attempted foreign Christian effort in more functional developing countries. Thus, it is demonstrable that countries with a lower HDI score, which, as shown above, have more restrictive gay rights policy, receive a smaller amount of foreign Christian effort, and that this smaller effort is actually going a longer 
way. Conversely, in more countries with a higher HDI there is a greater attempt at foreign Christian effort, it can be seen that the efforts are failing; as would be predicted by my theory.

\begin{tabular}{lcc}
\hline & Human Development Index & Significance \\
\hline Foreign Missionaries & $.4433^{* *}$ & .0009 \\
\hline$* * \mathrm{P}=.01$ or less, $* \mathrm{P}=.05$ or less
\end{tabular}

Table 4 - Missionary Placement, 2000

\section{QUALITATIVE METHODOLOGY}

The quantitative correlation evidence above suggested there is a correlation between the level of state capacity of the countries in question and the level of homosexual rights in that country. It demonstrated further that there is less missionary activity in countries that are worse off and more missionary activity in countries that are better off. This could lead to the conclusion that "less does more" in worse off countries. The quantitative evidence shows a correlation and qualitative analysis is now needed in order to flesh out and support the theory. To this end there are several case studies described below that demonstrate how the issues of the level of functioning, or lack thereof, in those case study countries, enable the foreign Christian groups to influence policy in the targeted countries.

If one looks at the social policy of less well-functioning states one sees more conservative/restrictive social policy in the less-developed world. If one looks at Western Europe and North America the debate as to whether homosexuality should be legal seems to be much more gay-friendly. This is evidenced by the existence of more legislation on the books that helps homosexuals than in less-developed states. If one looks at Latin America, a region that has many middle class countries, there is movement in the direction of liberalization with regards to homosexual issues and even some discussion of legalizing abortion. (ILGA Reports, 1998, 1999, 2007, 2009, 2010) (Human Development Reports, 1998, 2002, 2007/8) In Africa, however, which has the World's least developed states, there seems to be movement in the other direction. One can see 
efforts to make already restrictive polices, especially on homosexual issues, even more restrictive. (Kaoma, 2009, Kennedy, 2006)

According to the Central Intelligence Agency of the United States, African countries for the most part rank nearer to the bottom of per capita GDP scale, while Western Europe, North America, and Australia ranking much closer to the top. (CIA Website) Further, according to the Transparency International corruption index, Africa is, on average, much more corrupt than Western Europe, North America, or Australia. (Transparency International Website 2)

Discriminatory activities are not legal in South Africa, the most functional country in mainland Africa with according to the Human Development Index as of 2000. It only recently emerged from the Apartheid system but it has been re-accepted by African countries as an integral African state, and is a founding member the African Union, the successor to the Organization of African Unity. It is also a member of the Southern African Development Community. Since coming out of Apartheid it has continued to be one of the best off countries in Sub-Saharan as measured by the Human Rights Index. It is also an African country where homosexuality is legal, a fact which has remained through successive elections and four Presidents. It is also an African country where homosexual marriage became law in 2005, well after the free constitution was promulgated. As a developing African country with higher state capacity it has a thriving gay scene. Further it that has resources and clout to make their case to decision makers. (Kennedy, 63) This is evidenced by the successes the gay rights community has had in South Africa. South Africa has enshrined gay rights into its legal system, and has allowed gay marriage. (Gay Times.UK) (ILGA Reports 1998, 1999, 2007, 2009, 2010) In fact, South Africa is recognizing the value of the Gay market and it has been catering to the gay population both foreign and domestic. It has developed activities such as gay pride parades, the Out in Africa Film Festival, and the Pink Loerie Mardi Gras. Gays can hold hands and eat together as a couple. (BBC+) The ruling African National Congress has committed itself to defending gay rights in South Africa in spite of traditional opposition. $(\mathrm{BBC}+)$ In a speech to the Council on Foreign Relations, post-Apartheid Deputy President Frederick DeKlerk of South Africa, and the last Apartheid South African president, stated that since the end of Apartheid, South Africa has had stability 
and "the adherence to well-balanced economic policies, fighting inflation, doing all the right things in order to lay the basis and the foundation for sustained economic growthit's in place." (DeKlerk, CFR.Org) It is clear that there are more restrictive polices in Sub-Saharan Africa, almost all of which have lower state capacity.

To succeed in affecting the domestic situation in the target countries, the foreign Christian groups have to interact with domestic forces. If no one on the ground in targeted countries works with the outside forces there would be no effect in the targeted country. As such, the dissertation must focus on the interplay between the foreign groups and the domestic actors within the countries in question.

I use a case study approach to demonstrate how the foreign Christian groups are more successful in countries with lower state capacity. For the reasons described below I examine South Africa and Argentina as countries with higher state capacity and Uganda and Guatemala as countries with lower state capacity within the developing world. These countries were chosen for the following reasons. Argentina fits the category of a country with higher state capacity in Latin America with a relatively high Human Development Index score while Guatemala has a relatively low score. South Africa also has a relatively high score while is the recipient of a lot of attempted foreign Christian effort and thus is a good case to demonstrate how the foreign Christian effort works. Further, it is lower on the Human Development Index than many other Sub-Saharan African states. The case study portion focuses on key questions that support the conclusion that the foreign Christian groups have more success in exporting influence to countries with lower state capacity. There are three sections; these focus on the state capacity itself, foreign factors, and policy.

An examination of domestic factors is very important in demonstrating what it is about countries with lower state capacity that make them more open to foreign Christian effort. So I focus on them in determining how such foreign Christian effort is facilitated or harmed by these factors. This is the first independent variable. I demonstrate what it is about the targeted countries that make it more difficult to influence countries with a higher state capacity as opposed to ones with a lower level. As far as domestic factors are concerned three factors of importance are legitimacy, cohesion, and education. 
Governments that lack legitimacy will be looking for something to give them that legitimacy. Two important techniques are studied. One common technique of achieving legitimacy is establishing a common enemy so that a leader can gain the position of fighting against the common enemy, thus gaining support, thus gaining in the minds of the followers more of a right to rule. He/She is a leader verses an unpopular other. Another is use of a unifying ally, in this case the Christian Churches. Once again the leader can place him/herself as supporting this common ally and thus gain support and thus legitimacy that way. In countries with lower state capacity there exists the desire by some leaders to lead the state against an internal common enemy. This happens everywhere but it especially advantageous in states that have a lower state capacity where people have very little in terms of human development. According to Burns people will give legitimacy to those leaders who satisfy "popular wants, needs, and aspirations." (Burns, 434) Thus if a leader can create wants and aspirations in a society that can be filled by the leader in this case the leader of the "correct" religious philosophies and of societal attacks against those who live outside the "correct" way of life as prescribed by the "correct" religious philosophies then the leader can garner legitimacy. According to Pierce and Newstrom (2008) power comes from internalized values in those who follow that dictate the right of a leader to have legitimate power over the follower and that the follower will feel the need to accept this power.

If one can point to common enemies or friends being fought or supported by the leader he/she can improve his/her legitimacy by becoming a leader for what the society feels is correct and proper.

In this study I demonstrate that Gays are often targeted as a common enemy, or, in the case of abortion/abstinence, the leaders may be trying to shore up support for a common objective i.e. using the unifying power of the Christian Churches. In both cases, the case of unifying around a common enemy, gays, or unifying around a Church when it comes to restricting abortion, there is an attempt to unify social movement under the leader.

Another related factor which this work focuses on is that of state cohesion, or lack thereof. Leaders in states with less cohesion will be looking for a way to glue their countries together; religion can be used to that effect. This is important because 
countries with a lower level of state capacity tend to be (admittedly not always) less cohesive, as will be shown in the case study section, and, as such, leaders in these countries will be more desirous to find unifying issues for their countries. Thus, three issues are involved in determining cohesion, ethnicity and conflicts, class and conflicts, and religion and conflicts or lack thereof.

Education or lack thereof is the third critical factor. This is also being focused on in terms of two issues, literacy and being able to critically think. If people are unable to read they will have a more difficult time getting independent analysis and information. Further, if the people are used to thinking for themselves they can often evaluate information more rationally, if however, they are not trained to critically analyze information that is being given to them, they are more likely to just accept what is being told to them by social leaders Critical thinking is determined by high school attendance.

Another aspect of this study, and the second independent variable, as opposed to domestic factors, are those of foreign Christian effort. This study examines foreign Christian effort through its attempts to influence both the people and the governments. The first factor looked at are attempts by foreign religious groups to influence the people and leaders of the states in question. This first factor focuses on two issues. It investigates visits by foreign Christian groups to both people and leaders. Visits to the common people of a country help form public opinion while visits to leaders will help get the policymakers directly on the side of the penetrating groups in the states in question. A second issue involves money tied to the recipient's behavior such as aid conversion.

The second factor involves foreign governmental support for pro Christian causes by foreign governments that are influenced by their own home grown Christian groups. This are investigated in terms of aid money. This includes monies that flow to a country on condition they institute a morals policy such as reducing abortion or supporting abstinence.

Finally, the dependent variable, policy, this work qualitatively illustrates case studies. These studies describe how policy, the dependent variable, has been enacted, one way or another, in the key areas of gay rights and abortion/abstinence. Alternately, if policy has not been enacted, explain that this was due to the difference between states with a higher as opposed to a lower state capacity. It also takes into account serious 
attempts to change policy, both officially and unofficially, by the leadership and common people of the countries in question and examine the effectiveness of these attempts. Thus it is a combination of the two independent variables that will lead to policy.

The causal mechanisms will also be discussed in the qualitative sections. There are three types of mechanisms at work. These are aid conversion, leadership vulnerability, and education or lack thereof. This work will elucidate why a lack of legitimacy, or cohesion, or education assists foreign Christian groups influence societal policy in lower state capacity countries as opposed to higher state capacity countries.

Mechanisms involve 1) aid conversion, where people receive needed assistance in return for receiving a Biblical message, 2) leaders enhancing their legitimacy by cloaking themselves in religion, which garners legitimacy through religious means instead of democratic means, 3) religious-based cohesion whereby leaders use faith to attempt to bring together a country riven by division, and 4) how education or lack thereof plays a role in a counties ability to find other messages. This work will argue that these factors dovetail with a desire to maintain power when a leader has no legitimacy, the state has no cohesion, and the people have little or no education. The causal mechanisms are 1) that when the leadership of a country with a lower state capacity realizes it needs legitimacy and cohesion, they seek out these things for their own purposes, 2) that a lack of education means a populace that is less likely to garner alternate intellectual ideas, and 3) messages and aid from foreign Christian groups is a good way of gaining legitimacy, cohesion, and education. As a result policies that the foreign Christian groups support are made policy in the countries with lower state capacity. On the other hand, the leadership in countries with higher state capacity have little or no need to gain legitimacy or cohesion through the use of foreign Christian groups and that even if they did people are more educated and have ways of garnering and analyzing alternate information. 


\section{CHAPTER 4: AFRICAN CASE STUDIES}

\section{SOUTH AFRICA}

\section{Organization of this Chapter}

The following section will discuss the case study country of South Africa. Of the two African cases, South Africa is the one that has a higher state capacity, so I analyze it first. This section will discuss the case of South Africa in terms of its independent variables of state capacity, foreign Christian effort, and policy.

State capacity is analyzed in terms of the factors: legitimacy, cohesion and education. In the discussion of legitimacy and cohesion the technique of targeting a common enemy will be one of the means employed. First, it will be demonstrated that South African leaders have ways to establish legitimacy other than through attacking homosexuals. Secondly, state cohesion will be discussed. It is demonstrated that South Africa, although having social fissures, is relatively cohesive with regards to ethnicity, class, and religion. The third part of the state capacity variable is education. This will be demonstrated by literacy and high school attendance to determine the ability to gather information and critical thinking in a way that is not available in Uganda.

The second independent variable is foreign Christian effort in South Africa. The discussion will exhibit and discuss foreign Christian outreach activities to the South African population. After examining outreach activities, discussion will turn to aid conversion (i.e. the linking of aid to conversion or enhanced Christianity). It will then proceed to connections between leaders in South Africa and foreign Christian groups. After this I will discuss the efforts by Christians to get their home governments to influence the policies of South Africa in a pro-Christian way. The discussion will conclude with the global gag rule on abortion.

Following these discussions of the independent variables, the section examines the effects on the dependent variable policy. It will conclude with a discussion of causal mechanisms and then a conclusion. As stated in the Methodology chapter, policy positions are to be measured by two policy issues that are important to some Christian NGOs. These are gay rights and abortion/sexual mores. It will then discuss advantages that more socially liberal groups in South Africa have in comparison with the people of 
Uganda. Finally it will discuss important causal mechanisms. These involve three main causal mechanisms: aid conversion, leadership susceptibility/vulnerability, and education. It shows that foreign Christian effort is less successful in South Africa due to the fact that, although there is a great deal of foreign Christian effort, the causal mechanisms of a lack of legitimacy, cohesion and education do not exist in South Africa to the degree that they exist in Uganda. Therefore foreign Christian groups are not as successful in influencing policy in South Africa. The conclusion that will be drawn from this is that South Africa, which has a higher state capacity, is less open to foreign Christian penetration because of its higher state capacity.

\section{State Capacity:}

\section{Legitimacy}

This section discusses the importance of legitimacy for a government and further shows the active basis for legitimacy that was enacted by the South African Government. Legitimacy is critical for any government. Without it, the ability of the government to exercise its power over the people and resources it purports to govern is significantly reduced. Countries with more legitimacy in their governments have higher state capacity, as it is defined in this document then do countries with less legitimacy. Countries whose governments have greater legitimacy will be less likely to be influenced by foreign Christian groups than countries with less legitimacy because a country with low legitimacy may have greater need to work with outside groups as a means to provide itself with such legitimacy.

The practice of religion, such as Christianity, imported to a country from foreign Christian groups can be relatively more useful for countries that lack legitimacy, if these practices are in line with a domestic faction. This is due to the fact that the domestic government can place itself as the home purveyor of the foreign Christian ideology which it claims is correct. Hence, the leaders of the country can garner much needed legitimacy through being the instrument by which the "correct" way of life, the way of life that God supports, is put in place. Leaders of countries with more internal grounds for legitimacy, 
such as that gained through democracy; do not need the foreign Christian groups and their philosophies in order to claim to be the legitimate leaders.

Since the end of Apartheid, South Africa has demonstrated a strong democratic tradition. It has had three free-and-fair elections, with one man one vote. It has had four presidents, all inaugurated under legal free and fair means. The first president Nelson Mandela was a national hero. He was succeeded by Thabo Mbecki who resigned and was, in turn, replaced by Kgalema Motlanthe. Finally, Motlanthe was replaced with the current president, Jacob Zuma.

Although not completely accepted by all people in the South African populace, South Africa has put forth the concept of the Rainbow Nation in order to strengthen its legitimacy. "The rainbow symbol has been exploited for commercial purposes as well as political ends." (Moller, 246) This concept of the rainbow helps bind the people of South Africa together in unity. This is a change for the Apartheid system where racial division was very real. South Africa has a more collectivist system, rather than instead individualistic one. (Moller, 247) In fact the rainbow nation takes the form of a civic religion (Moller, 249) and this helps increase the legitimacy of the government of the new South Africa. Although this symbol is not totally accepted, about half of the South African population believed in it as of 1996. (Moller, 254) The ideal of the rainbow nation has seen some decline in recent years with $49 \%$ holding the idea that race relations were better in 2009 than in 1994. (Smith) Still this is almost 50\% and thus almost half of the population does see this ideal as a legitimizing factor. Further, it provides a legitimizing aspect to the current system of government in South Africa. The government of this new South Africa has the legitimacy of a unifying force that does not require the importation of foreign Christian groups to maintain.

There was an organization that has helped South Africa achieve legitimacy through means other than the importation of foreign religious doctrines to unify its people. This organization was the Truth and Reconciliation Commission. The Truth and Reconciliation Commission was a commission designed to publicize the negative acts committed by the Apartheid Government of South Africa. Its goal was to provide a forum for the truth. It did this while at the same time giving a non-punishing forum to those who were honest in what they said to the commission. This commission under the 
leadership of Archbishop Desmond Tutu worked very hard to perform both nation building and healing in the post-apartheid society. (Vora \& Vora, 305) It also had as goals, amnesty, reparation, and rehabilitation to those who committed human rights abuses during the apartheid regime. (Vora, Vora 306) According to Vora \& Vora (2004) three of the main ethic groups, the Xhosa, Afrikaner, and English, held the belief that this commission was successful at getting to the truth about the negative acts committed under the apartheid administration. There was a racial dimension to the perceived legitimacy and belief in the usefulness of the commission. The Xhosa felt that the commission had legitimacy and was helpful to a greater degree than the English. The Afrikaner population was even less convinced about the legitimacy and helpfulness of the commission. (Vora, Vora, 310) What the Xhosa believe is important, because the Xhosa are the second largest group after the Zulu. In addition, they form a leading supplier of leaders such as Mandela, Tutu, and Mbeki. Their importance is further demonstrated by the fact that they are significantly larger in population than the English or Afrikaner groups. In its post-Apartheid era, the country of South Africa strove to legitimize itself not through the use of foreign religious actors, but through the coming together of its people to deal with the problems of the past through a non-religious, certainly nonforeign Christian, influenced forum.

If one looks at this study by Gibson (2005) one can see that in spite of some of the disagreements listed above, the Truth and Reconciliation Commission is supported by a majority of South Africans of most races. In the case of non-white, non-mixed race South Africans, 69.9\% either strongly approve or somewhat approve. In the case of Whites $50.4 \%$ strongly disapprove or somewhat disapprove. In the case of people who are of mixed White and African ancestry $45.1 \%$ strongly or somewhat approve but there is a large number $38.6 \%$ who have not made up their minds. This leaves only a small $16.3 \%$ strongly or somewhat disapproving of the commission. Finally, with the South African Asian population $61.2 \%$ strongly or somewhat approve of the commission. This leads us to the conclusion that there is indeed support for the commission, especially in the largest ethnic group surveyed, the Native African group. (Gibson, 345) Importantly, South Africans have developed some acceptance with regards to what their opponents have done in the fight to end or keep the apartheid system in South Africa. 
What this tells us is that South Africa does not need a common enemy in order to maintain its legitimacy. It has the capacity to organize ways of bringing people together without a common enemy. As stated, it has a democratic system and legal system that enable its leaders to gain legitimacy through the ballot box.

\section{Cohesion}

South Africa is more cohesive than Uganda. Cohesion for the purposes of this document is defined as how fractured a country is and the salience of those fractures. A state that has religious, ethnic, or class fractures that are salient would be considered less cohesive. A country without those fractures or where those fractures are not salient would be considered more cohesive. South Africa does have ethnic and class divides which are salient and also related. South Africa is better able to overcome these stressors to have a relatively ordered country.

The wealthiest group in the country is the Whites, while the poorest people are the native black African population. The South African Institute of Race Relations points to statistics that state that $51 \%$ of the youth of South Africa is unemployed. Two thirds of those are African women. In South Africa ethnic groups mobilize along such ethnic lines when it comes to the division of the resources in the country. (Irobi, 2005)

The level of class conflict can be observed not just by the disparity in wealth between rich and poor but in action taken by one class against another. This can be shown by strikes. Interclass hostility has erupted in South Africa for several years. South Africa has been beset by numerous strikes that happen at roughly the same time every year in mid-summer in what is called strike season. In 2010, people from many walks of life struck including hospital staff. The striking was so acrimonious that patient care was interfered with. The problem got so bad that the army had to be deployed in order to keep some hospitals open. (Smith)

These strikes also affect the politics of South Africa as well as that country's economic competitiveness. (CSM) The South African unions believe that higher wages will help in the fight against inequality and further seek to ban day laborers that have the effect of bypassing the unions. They are linked to the ruling African National Congress through the Congress of South African Trade Unions which is a partner to the ANC. They are opposed by employer associations that argue that the demands put forth by the 
Unions are not reasonable and that the policy of banning the day laborers would create large amounts of unemployment. (CSM)

It must be stated that in spite of the apparent lack of South African social cohesion the country with state capacity is able to protect the rights of its minorities anyway. South Africa has something that Uganda does not in terms of dealing with societal anger and that is legitimacy. According to Steve Friedman at the University of Johannesburg, "South Africa is a democracy. When people are unhappy they can vote the government out." (CSM) South Africa also has the national motto of a rainbow nation where people of all different backgrounds can live peacefully although as stated above this has weakened some it is still a presence for just under half of the population. South Africa posits positive unification instead of negative and the results are clear with the protection of South Africans of all backgrounds in their constitution. The government in this more functioning country does not need to divide and rule. It has not turned to religion to keep itself legitimate. South Africa has ethnic and class divisions. These divisions are not, however, dealt with in the same way.

\section{Education}

Education is a critical factor in determining one's ability to think for oneself. I will demonstrate that when it comes to these countries, those with lower education levels are more likely to be influenced by foreign Christian groups that are attempting to influence policy in a targeted country. In this section I will discuss two important measures of education. One will be the literacy rate of South Africa, the other being secondary school education. I will demonstrate that developing countries which have lower education levels are more open to foreign Christian penetration.

The literacy rate is critical because people who can not read have a reduced ability to get information. If one can not read, one can not gain information from any written sources. This includes newspapers, magazines, and much of the internet. As such, it would be harder for an illiterate person to get independent analysis and information to create their own opinions and they would be more likely to rely on ideas put forward verbally, in the missionary style used by the foreign Christian groups. The literacy rate for South Africa as of 2007 is $82.4 \%$. South Africans have a greater ability to get 
information on their own than the people of Uganda which has a lower level of literacy, 66.8\%. (Almanac, 2007)

Another key element of being able to gain and process information is the ability to think critically. If a person has not been intellectually trained to look at a policy and then analyze it critically they are more likely to be influenced by others, in particular, by foreign Christian groups that are targeting them and their country if the individual in question can think critically.

Education and the corresponding increase in the ability to think critically, is demonstrated by the total amount of time students spend in school as of 2007 and net attendance as of 2005-2009. South Africa has a rule that as of 2007 attendance is mandatory for years 7-15 for a total of eight years as opposed to Uganda's six years. (Almanac, 2007) Attendance in secondary school is $41 \%$ for males and $48 \%$ for females. (UNICEF 3)

According to the World Bank, the school systems of South Africa versus Uganda vary in terms of resources leaving aside attendance. In 2008, South Africa spent 13.7\% of its Per capita GDP on education. Uganda, on the other hand, only spent $8.5 \%$ of its much lower GDP per capita on education. (World Bank)

\section{Foreign Christian Effort Directed at South Africa}

The first discussion regarding foreign Christian effort will refer to foreign attempts to reach the masses of South Africa. Foreign Christian groups have indeed been active in attempting to influence the people of a country to follow their interpretation of Christian doctrine as put forth by these groups. The foreign Christian effort of Pastor Benny Hinn, the Association of Baptists for World Evangelism, Kenneth Hagin Ministries, and Pastor Billy Graham and his son Franklin Graham will be discussed.

\section{Outreach: Benny Hinn}

Benny Hinn has traveled worldwide in order to preach Christian beliefs to people. He is a faith healer. Benny Hinn is known to be a firm opponent of homosexuality and has preached against it. He has called homosexuality a perversion, and has stated that "homosexuality and perversion are connected" and that it is a "spirit of perversion" and has attacked pastors who accept homosexuality. (YouTube Hinn, Benny 1) 
Benny Hinn has been active in South Africa. He led the Holy Spirit Miracle Crusade in South Africa in 2008, in the 18,000 seat Coca-Cola Dome where he has engaged in faith healing and spreading the word of Jesus Christ. (Hinn, Benny2) Further Benny Hinn is quoted as stating "'God is doing mighty work here in South Africa" (Hinn, Benny 4)

This was not Benny Hinn's first Crusade to South Africa. He also went to South Africa in 2002. At that time he led the Holy Spirit Miracle Crusade where he preached the power of Christ and talked to a women whose prayer to God (in theory) cured the women of AIDS. (Hinn, Benny3)

Although homosexuality and abortion were not the main thrusts of the revivals that Pastor Benny Hinn led, he did influence people towards the type of Christianity that he supports. He claimed that he could heal the sick through the power of God and theoretically demonstrated this to the people present. As such, the people in the audience behaved as though Pastor Benny Hinn was someone to look up to and support. In other settings, Benny Hinn has attacked homosexuality as perversion and something should be that was unacceptable to his followers.

\section{Outreach: Association of Baptists for World Evangelism}

Another group that has taken an interest in South Africa is the Association of Baptists for World Evangelism or ABWE. ABWE was founded by Raphael C. Thomas in the 1920's. ABWE began what it refers to as church planting missions in South Africa in the 1980's starting in Durban, where there are now ten churches. Five of these churches are run by South Africans while the remaining five are run by a mix of missionaries and South Africans. According to ABWE's Statement of Principles and Practices Sixth Edition "Sexual immorality shall be defined as adultery/fornication, incest, sexual molestation, lesbianism and homosexuality, and habitual use of pornography." (ABWE Statement, 21)

A major goal of the ABWE's South African mission is to train South Africans to evangelize in their own churches and to this end the fellowship of Churches has created the Baptist Bible College of KwaZulu-Natal and have begun an effort to plant churches among the Zulu population. (ABWE Website) 
Efforts are now underway to reach the people of the Western Cape Province of South Africa. The attempts to minister to the region started in Pre-Apartheid South Africa and have continued over to the Post-Apartheid era. This has continued with ABWE led Churches in Cape Town and a further three that are attempting to reach the Xhosa people.

In 2001, ABWE developed what it refers to as a "Cape Master plan." This involves outside missionaries working with South Africans to bring their version of Christianity to the people of the Cape. "These support ministries include the Church Ministries Institute, the Paardeberg Mountain Retreat, and the Good Hope Christian Schools. Other partnership ministries include the Vision in Action Trust, the Herald of Hope Ministries (SA), and the Ministry Resource Forum." (ABWE Website2)

The Cape Church Ministries Institute trains lay leaders in South Africa including evangelists, deacons, missionaries, and pastors. This ministry is connected to the South African Government's accreditation through South Africa's Northwest University in Potchefstroom. The Paardeberg Mountain Retreat manages family and youth camps, seminars, special events, and church retreats. According to the ABWE website, their work through this "camp/retreat center has proven to be a great evangelistic and disciplining support ministry for church planting in Cape Town. Here in God's creation, individuals and families are challenged to know Him better and live for Him." (ABWE Website 2) Moreover, the Good Hope Christian schools works with children and families to learn to "serve the lord in all areas of life." (ABWE Website 2)

The Garden Rout was created in 2009. The Garden Rout geographically is a section of South Africa stretching from Heidelberg to Storms River. The team responsible for this area is running a collaboration of American and South African pastors and other people with similar faith goals.

In summary, $\mathrm{ABWE}$ has a foreign element that is using its power to influence the people of South Africa. The group plants churches, leads retreats, provides education, and has been expanding its efforts to influence South Africans. As such it can be seen that the ABWE movement has the potential to influence South Africans. It can also be seen through their own writing that the ABWE movement opposes homosexuality 
and thus would be an organization that would use its influence and power to lead people in a direction that was against rights for homosexual people in South Africa.

\section{Outreach: Kenneth Hagin Ministries}

The next group that will be discussed is the Kenneth Hagin Ministries and their associates in the Rhema Ministries in South Africa. On Kenneth Hagin's own website the ministry's opinion on homosexuality is explicitly stated. They argue that some people do not know what uncleanness is. Their website goes on to say that uncleanness, when discussed in the Bible, refers to lesbianism and homosexuality. The site goes on to say that the Holy Spirit, through his agent, the Apostle Paul, would not permit people to perform these acts of uncleanness. Further the website goes onto say that if God is asking us to do something such as honor our bodies, something that we have the ability to do; God would not ask us to do something we could not do. (Hagin Website 1)

The Rhema Ministries share a connection to South Africa through the Rhema Bible Training Center in Tulsa Oklahoma run by Kenneth Hagin. On Pastor Ray McCauley's own Facebook page he describes his activities in South Africa. According to his own statement he is the senior pastor of Rhema Bible Church and is the president of the International Federation of Christian Churches. Although born in Johannesburg South Africa he was trained religiously in the United States and returned to South Africa after his training was complete. Upon returning to South Africa he began Rhema Bible Training Center, under Rhema Ministries. The Church has grown over the years and now has a membership of 45,000, making it the largest congregation in South Africa. (McCauley's Facebook Website) His religious views and his zeal were at least partially shaped by the Rhema Bible Center.

\section{Outreach: Cape Town 2010}

Another example of the importance that the evangelical movement attaches to South Africa is the $3^{\text {rd }}$ Lausanne Conference otherwise known as Cape Town 2010. The Lausanne movement was founded by American Pastor Billy Graham. Billy Graham, although not physically present at the most recent conference, still participated through a letter that was read to the participants in which he stated that "the love of God, the good news, and Christ's commandments do not change."' (Graham) He has spoken out against 
the rights of homosexuals, specifically attacking their right to marry. Further, on his own Website one can find discussions of how a person can be "liberated from homosexuality through the power of Jesus Christ."” (BillyGraham.Org)

The first conference had been held in Lausanne Switzerland and released the Lausanne Covenant. This document emphasized the Bible as "both Old and New Testament Scriptures in their entirety as the only written word of God, without error in all that it affirms and the only infallible rule of faith and practice." (Lausanne Covenant)

Cape Town 2010, also known as Lausanne 3, was the third such conference. In this conference 4,000 leaders from 198 countries were in attendance with thousands participating in seminaries, mission agencies, and radio networks from the Cape Town Global Link. (Lausanne Website)

In this conference most leaders agreed on important social issues such as abortion and gay rights. According to Boyd $96 \%$ opposed abortion while $84 \%$ believed that homosexuality was wrong. (Boyd) According to the conference director, Blair Carson "we want to be a grounding for a whole new movement communicating the gospel of Jesus Christ"” (Boyd)

This is important in that it reaches out not just to the people of South Africa which it has done through the location of the Third Conference but also people around the world. The decision to place the conference, which had been founded by an American, of which there have only been three main conferences in about 40 years, demonstrates to the people of South Africa that Christianity is reaching out to them and will make the people of South Africa feel special in the eyes of global Christianity.

\section{Outreach: Summary}

The above several examples, demonstrate that there are significant attempts by foreign Christian groups directed to influence the people of South Africa. These attempts are often more subtle than those in Uganda but they are indeed occurring even without receiving media coverage as has been given to Uganda. As such, it is demonstrated that there are very significant attempts at foreign Christian effort in South Africa just as there are efforts in Uganda. That these groups are attempting to influence the people of South Africa demonstrate that South Africa is considered important for the global evangelization effort and the importance that evangelism places in influencing the people 
of the country of South Africa. South Africa is one of the few fully functioning democracies in Africa and if the evangelicals can prompt or convert enough people they can influence the laws of the country via the legitimatizing ballot box. As such, South Africa is an important piece in global evangelism. Further, if they can achieve a social impact in South Africa they can make the argument that they represent Africa better than the evangelizing movement can if they make such strides in Uganda. South Africa holds a special place in Africa due to its size and the successful fight against Apartheid. It has also become a member of important international organizations. It has been admitted to the BRIC block, and is a member of the G-20, the only African state to be admitted to that organization. (G20/G8.com) According to Jacob Zuma the President of South Africa it is important to have Africa represented in the BRIC block because that way Africa is represented. (MacLeod) South Africa was also the first African country to hold the World Cup. This is something considered very important by African soccer (football) fans. It is thus a moral beacon for Africa as it achieved an end to effective colonialism (relatively) peacefully and established a successful multi-racial state that is peaceful with its neighbors. It thus has a great deal of soft power in Africa.

Importantly, according to the Transformation Index South Africa is open to interest groups and the number of interest groups in South Africa is described as dense. This is due to the level of state capacity relative to other African countries. This is the case due to the fact that South Africa is half industrialized. (Transformation Index)

\section{Aid Conversion}

Aid conversion is another important way in which foreign Christian groups influence people from the developing world. In this section I will examine the connection between foreign Christian effort and aid. Developing countries often require outside aid in order to meet the needs of their people. Although South Africa is better off than Uganda, it still has trouble meeting the needs of its poorest citizens. This section discusses groups that tie aid to foreign Christian effort. This includes aid given by organizations whose leadership attempts to push the acceptance of Christ, or stronger evangelization with those who already profess Christianity, as the religion of the recipients of the aid. 


\section{Pat Robertson}

First, I will examine Reverend Pat Robertson's activities. He is on record as attempting to convert people to Christ and has an organization connected to his television program called the $700 \mathrm{Club}$. He is also fervently anti-abortion and anti-homosexual. This organization is called Operation Blessing. Even the name of the organization has a Christian connection reefing to the blessing of Christ. He is also fervently opposed to homosexual rights and abortion.

South Africa is a target for Operation Blessing, which has been active throughout the world including in South Africa. According to Ken Pettitt the regional director for Operation Blessing's Africa activities, it dedicated resources to help with the fight against AIDS in South Africa. This includes serving up to 38,000 meals as well as 3,200 home visits every month. (Operation Blessing1)

Another example of Operation Blessing's work in South Africa is their work helping women start sewing operations. Operation Blessing starts home production in the women's homes. This is done for women who can not leave their homes. For women who can travel more easily, they go to a production center. These represent the poorest of South Africa's people. Some have AIDS; some are prostitutes, while others are single parents. These workers now fill orders for school uniforms, bathroom sets, shirts, and curtains. Operation Blessing emphasizes Christ in its activities demonstrating this when it placed on its website a testimonial from one of its participants Mieime. She was a women helped by this program and she stated that "I believe we will make a living and help many people to know Jesus and put bread on the table for the children."” (Operation Blessing 2) Pettitt has stated the religious aspect of this organization when he stated "I am humbled by the endurance and tenacity of these people. The generosity of our partners to the endurance of our participants -- it all points to the great love that God has for mankind." (Operation Blessing 2) It is therefore clear that spreading the Christian message is tied to the aid being given to the people of South Africa.

Franklin Graham and Samaritans Purse

Franklin Graham, the son of the well-known American Pastor Billy Graham, has made his feelings on gay rights clear. He has expressed concern regarding the feelings of 
President Obama on gay marriage as well as on the issue of abortion, stating that he and his father believe the Bible speaks firmly on the issue of gay marriage thus he opposes marriage for homosexuals. (Baker)

Franklin Graham is also the leader of an international aid organization called Samaritans Purse. Samaritans Purse works to assist those who are victims of famine, war, and natural disasters among other problems faced by those in the developing world. They feed and clothe children who are vulnerable. Further, they give treatment in the name of "the great physician." (Samaritans Purse1) Franklin Graham has as stated goals proclaiming the gospel of Jesus Christ. Further he works to help people around the world meet their needs. He is the CEO of the Organization Samaritans Purse. (Samaritans Purse 2)

When asked by those who are being helped by the assistance provided why they have come to help they clearly respond that they come in the name of Christ. They argue that they do not preach themselves but Jesus Christ. (Samaritans Purse1) They are very clear and open about the fact that they do what they do in order to advance Christ in the developing world. According to their Website "The organization serves the Church worldwide to promote the Gospel of the Lord Jesus Christ." (Samaritans Purse1)

They have directed effort to South Africa. One way they have done this is to help with the AIDS epidemic that is unfolding in South Africa. South Africa has one of the worst AIDS rates in the world. Samaritans Purse works to help such people including partnering with groups to bring Bible literature to those who are suffering the effects of this disease. According to Samaritans Purse they work to provide Bible-based education, chaplain training, orphan care, hospice care, as well as medical assistance. South Africa is one of the countries in which they are active. (Samaritans Purse 3)

Another effort that Samaritans Purse has put forward was Operation Christmas Child. This is an effort to bring gifts to children of the developing world. South Africa is included among the countries receiving gifts. Missionaries working with Samaritans Purse worked to gather resources in the United States and deliver them to people in their mission in Kenya and South Africa. The supplies included crayons, toothbrushes and paste, and toys. These were not the only things they had included; another was religious literature in the form of a 38-page color book. (Samaritans Purse4) 
These examples demonstrate that aid is tied-in with ideology. It is evident that in the case of aid tied to a religious message there is an attempt by powerful outside Christian groups to use resources targeted to desperate people in need in order to achieve an objective.

There is the desire by these foreign Christian groups to tie aid to the message of Christ. Even when ministering to those who are already Christian beliefs they invigorate their beliefs. When ministering to those who do not believe, they attempt to influence those who are already in trouble by combining the message of Christ with much needed material assistance. This is the case whether or not the people who are in need of help are forced to convert or not. When someone is in trouble and a powerful outside group saves their life or lifts them out of total despair, they are likely to have a positive view of the person or group helping them. They will therefore be more likely to turn to the belief structure of those helping when that belief structure is meshed with the necessary material aid. According to Maslow, the most basic needs such as food and medical care are those that are focused on first. If one gets those basic needs met through a reassessment of needs that are higher up on the pyramid, and thus less important, one will make that reassessment.

\section{Attempts to Influence Leaders}

In South Africa there is also a connection between foreign Christian organizations and the local leaders. As discussed above, Rhema ministries in South Africa has a very clear connection to foreign religious groups. The leader of South Africa's Rhema ministries, Ray McCauley attended the Rhema Bible Center in Oklahoma before moving back to South Africa and is also proudly the president of the International Federation of Churches. Thus there is a significant connection to, and influence from, foreign Christian groups in the Rhema Ministries. This is the case as the founder and leader was trained by an American Christian Group and leads an organization that spans many countries. As far as homosexual rights and the right of a woman to have an abortion in South Africa, the Rhema Ministries has made it clear that it wants to rescind the South African legislation that has allowed homosexuals the right to marry and the legalization of abortion. (Rossouw) 
This organization has links to the leading South African Party the African National Congress and its head Jacob Zuma, the current president of South Africa as will be discussed below. Further, the Rhema Church has formed the National Interfaith Leadership Council or NILC. The ANC MP Nthabiseng Khunou is a member of the NILC along with three other ANC MPs including the chief whip Mathole Motshekga. Although McCauley has claimed that no formal links exist between the African National Congress and the NILC, (Rossouw) it is clear there is overlap between them. Further, Khunou has personally stated opposition to gay marriage and legalized abortion stating "'I know churches want them abolished, so the reason for the NILC is to give a voice to people who don't have it."' (Rossouw)

Another example of the closeness between the Rhema Church and the South African leadership is the fact that Jacob Zuma attended the Rhema Church to ask for prayers for a peaceful election in 2009. According to Zuma, "We urge the Church to pray for a peaceful and fair election and easy transition to the new government .... and nation building." (Mail\&Guardian Online) Zuma also asked the church to pray for events that were coming up in South Africa such as the 2010, World Cup that would shortly take place. At the end of Jacob Zuma's speech Ray McCauley stated that "we pray for peace in our nation...we pray for our leader and we pray for absolute peace during the election." (Mail\&Guardian Online) Rhema has stated that they welcomed the visit by Jacob Zuma and his associates as it gave Rhema an opportunity to minister to leader of the ruling party in a significant way. (Mail/guardian Online2)

In South Africa, the well functioning state, Zuma was forced to apologize for antigay comments after criticism from the gay community. His comments were referred to by the Joint Working Group (a gay rights organization) as a "form of hate speech." (BBC1) Further they argued that someone so narrow-minded could not lead the country. Zuma backed down and is quoted as saying he stated that this was the traditional view regarding how he was raised and that it was not meant to condemn homosexuals. Further, homosexuals were very helpful in their contributions to bringing freedom to South Africa. (BBC1) This is important because when this leader of a well-developed country, one with higher state capacity, was caught making anti-gay comments he was 
forced to back down, whereas in Uganda the anti-gay behavior was not retracted but has intensified.

\section{The Gag Rule}

An important aspect of foreign Christian effort is when Christians in a donor country use their influence with their own home government to affect its foreign policy in such a way that it affects the policies of a targeted foreign country. This is not often applied to issues of gay rights.

In the United States, a major donor country, domestic Christian groups have used their influence with Republican administrations in the United States to tie certain aid to the fight against abortion. The Republican Party gets much more support from rightwing Christian groups than the Democratic Party. This has been evidenced by the Moral Majority's support for Ronal Reagan in 1980; Pat Robertson's run for president in 1988, and the general alignment of right-wing Christians with that party. According to a 2012 poll, White Evangelicals or Born Again Christians made up 50\% of Republican Primary Voters as on March, 2012. Further, a plurality of those supported the conservative candidate, former Senator Rick Santorum. According to Ralph Reed a conservative Christian activist, Conservative Christian Turnout has increased in the 2012 Republican Primary cycle where it was at $44 \%$ in 2008 . (CBS+)The major way this group affects policy is through the "Gag Rule." This rule was first established during the Reagan Administration. According to this rule foreign non-governmental organizations that are recipients of aid from the United States are not allowed to offer abortion as an option to the individuals that use the service that is receiving American aid. Further, those organizations are not allowed to lobby for abortion rights in their countries. President Bill Clinton repealed it upon entering office in 1993. Clinton's successor, President George W. Bush re-instated the measure upon taking office in 2001, and then President Barack Obama repealed the Gag Rule upon taking his taking office in 2009. (Sullivan) The administrations of Reagan, George H.W. Bush, and George W. Bush were all influenced by, and associating with, domestic right-wing Christian groups to a much greater degree than the administrations of either Bill Clinton or Barack Obama.

The Gag rule has failed to influence the policy of South Africa. South Africa allows abortion at the request of the mother. South Africa made abortion legal in 1996. 
Women can have legal abortions on the will of the mother for the first trimester. This act was challenged in court by the Christian Lawyers Association. This attempt failed and abortion remains legal in South Africa. (United Nations Abortion Report South Africa)

In South Africa NGOs led efforts have helped in the fight to keep abortion safe and legal. (Crane, 131) International NGOs, however are the organizations where the gag rule hits because not only does the gag rule stop NGO's from receiving US Federal funds but any organization, as stated above, that works to keep or make abortion safe and legal is barred from these funds. This is the case regardless of whether or not these groups actively perform abortions. As stated, this rule has failed to halt implementation of prochoice policies in South Africa.

\section{$\underline{\text { Causal Mechanisms }}$}

Leaders are driven to stay in power and have influence or control over the societies they live in. South Africa has been more resistant to the influence of foreign Christian groups than Uganda because South Africa has the benefits of higher state capacity in the areas of legitimacy, cohesion, and education. This results in less need for the leadership to implement what foreign Christian groups want and more ability to find other ways of leading. This has had the effect of allowing the South African administrations other mechanisms to stay in positions of authority. In particular:

- Legitimacy

- The fact that South Africa is a fully functioning democracy means that they can use democratic legitimacy as a mechanism for the justification of their leadership and do

- Cohesion

- South Africa uses the concept of the Rainbow nation and the Truth and Reconciliation Commission. These mechanisms make society more cohesive as opposed to needing religiously based cohesion

- Education

- The people of South Africa can garner information from many sources and analyze it due to their better education. The mechanism here is that due to the higher education levels South Africans are less beholden to the teachings of foreign Christian Groups 
The areas where foreign Christian Groups might have an impact in such areas as legitimacy, cohesion, and education are already filled by other societal mechanisms.

\section{$\underline{\text { Policy Effects }}$}

South Africa, the country with greater state capacity of the two that I am examining, has been at the forefront of homosexual rights in Africa. It has enshrined gay rights in its constitution. In South Africa homosexuality is legal, there is an equal age of consent, a prohibition on employment discrimination, one can not incite hatred against homosexuals, and there are rights for joint adoption by homosexual couples. (ILGA, 2010) In 2005, the Constitutional Court of South Africa declared un-constitutional the previous definition of marriage as being between a man and a woman. This paved the way for a change in South African marriage laws. In 2006, the South African Parliament, led by the ruling African National Congress, which ordered its members to vote yes on the change and also to be present for the vote, voted in favor of legalized marriage between people of the same gender. South Africa thus became the first, and to date, the only country in Africa, to not only constitutionally protects homosexuals from discrimination, but also to allow its homosexual citizens to have equal rights to marry. $(\mathrm{BBC} 2)$

In regards to abortion, South Africa passed the Choice on Termination of Pregnancy Act in 1996. This act allows women more control over their reproductive lives. Accordingly, this act grants a woman the right to request an abortion at any time during the first twelve weeks of pregnancy thus making South Africa a country where abortion is available on request. (Pregnancy Act)

\section{$\underline{\text { Conclusions }}$}

South Africa's leadership, unlike the leadership of Uganda discussed next, has democratic legitimacy with the rule of law. This is enshrined by a constitution that is enforced by the South African government, and which firmly bases the state and nation on a set of principals that are not based on religion, and which are in line with the foundational beliefs of most of its citizens. There is also an established tradition of smooth transitions of power, in line with the outcome of free and fair elections. Therefore, South African leaders are not as likely as some others to turn to populist 
religious policies, since they do not require religious legitimacy. They do not need the support of religious groups to the degree that Uganda does. In fact, although there are disputes between groups, the country attempts to maintain its cohesion by attempting to emphasize a common people in the rainbow nation. As will be seen, this is as different from Uganda, where the government of President Museveni attempts to garner his legitimacy through in-group versus out-group conflict. South Africa attempts to bring all South Africans under the umbrella of the national in-group rainbow nation policies. Further, South Africa has a relatively better education system than exists in Uganda. This allows people to gather their own information and analyze it to a larger degree then the people of Uganda have. The government of South Africa is also not as in fear of protest or dissent as the government in Kampala.

South Africans can speak freely and protest if they do not like a policy or try to change policies to those they do like. In Uganda the ability of people to protest in favor of gay rights, a policy the government opposes is limited or non-existent. As such, the pro-gay rights groups in South Africa have a much better ability to inform and fight for their beliefs to be put into policy than do the pro-gay rights people of Uganda. In South Africa, while there are many pre-existing homophobic beliefs from both the White Apartheid Era and from traditional African culture, these pre-existing beliefs have failed to carry over to policy.

The connections between the domestic and foreign independent variables are that external effort has less of an effect when the leadership is not vulnerable because of the country's level of legitimacy, cohesion, and education as is the case in South Africa. As a result the ground in South Africa is not as fertile for foreign Christian groups to influence policy as it is in Uganda.

\section{UGANDA}

The purpose of this section is to discuss how foreign Christian groups have influenced Uganda's social policy. Uganda is a country with lower state capacity, allowing us to discuss effects that contrast with South Africa, with regards to homosexuality and abortion/abstinence. This is demonstrated by the connections between the domestic and foreign independent variables. The lack of legitimacy, cohesion and 
education gives more fertile ground for the efforts of foreign Christian groups to influence policy.

\section{Organization of this Section}

Like the previous chapter, this chapter begins with a discussion of Uganda's state capacity, in four parts: its domestic factors, legitimacy, cohesion, and education. The next section then discusses foreign Christian efforts, prefaced with a discussion of the recent Ugandan bill proposing a death penalty. The direct effect of visits and interchanges between Ugandan leaders and Foreign Christian leaders is examined, as are the indirect effects of exploiting aid channels. It will then discuss causal mechanisms specifically. The final section discusses the effects these efforts have had on Ugandan policy and on the resource starvation of opposition to anti-homosexual forces.

\section{State Capacity:}

The following sections regarding issues of Ugandan state capacity are included to illuminate the domestic factors applicable in Uganda and to describe the absence of state capacity as it exists in Uganda. Uganda is a good example of a country that has seen serious problems. It is doing better than some, like Ethiopia and the Democratic Republic of Congo, but worse than others like Gabon, Botswana, or South Africa in terms of per capita GDP as of 2007. (Almanac)

\section{Domestic Factors: A Low Functioning State}

A useful indicator in evaluating the state capacity of Uganda is its Human Development Index. Uganda ranks in the Low Human Development section of the HDI, ranking 143 out of 169 countries studied, according to the United Nations Report. Further, Uganda scores a low 2.5 on Transparency International's Corruption perceptions index as of 2010. (Transparency Intl Website) Thus, Uganda has very few of its resources put into the betterment of their people, with much going to corruption. This problem is heightened by the fact that Uganda is already a poor country, and thus controls very few resources at all to split amongst its population.

Uganda has had a difficult history and is a country that has very recently been wracked by civil war, the war between Uganda and the Lord's Resistance Army. 


\section{Domestic Factors: Lords Resistance Army}

The Lords Resistance Army is led by Joseph Kony. The theory that drives the army is the claim that it wishes the government of Uganda to abide by the Ten Commandments, although their behavior is quite different from what others believe those instructions describe. They committed terrible atrocities in Uganda including the maiming, enslavement, and rape of children. Many of the abducted were forced to join the Lord's Resistance Army or forced into sex-slavery. People throughout Northern Uganda have been displaced and have often had to enter camps which are protected by the Ugandan army. (GlobalSecurity)

\section{Domestic Factors: Religious Conflicts}

The Milton Obote regime collapsed in the face of the movement of Yoweri Museveni who now rules Uganda. (Ward, 2000, 216) The collapse of the Obote regime in 1986 inspired Alice Lakwena and her relative Joseph Kony who founded the Lord's Resistance army following the overthrow of the Obote Regime. (Ward, 2000, 189)

\section{Domestic Factors: Civil War}

Before the Obote Regime, Uganda was ruled by Idi Amin. He committed terrible human rights violations, such as the forced expulsion of Ugandans of Indian descent and the torture of his perceived opponents. His reign was ended when he attempted to invade Tanzania and was in turn driven out by Tanzanian forces. He went into exile in Saudi Arabia. As I noted above, Uganda is also just emerging from the scars of civil war. Although the LRA has largely gone to other parts of Africa such as the Central African Republic and the Democratic Republic of the Congo where they are still causing harm and international outrage, the people of Northern Uganda are getting back to their lives, many scars remain. There remain the horrible memories of what had occurred including burning of villages, rape, abduction and murder. Damage includes both physical and mental injuries that will never fully heal. Yoweri Museveni, the current ruler, is unpopular in Northern Uganda and he is hoping now that the war is over he can make some political progress in this devastated area whose inhabitance feel they were not protected enough by the government in Kampala. (BBC3) 


\section{Legitimacy: The President Museveni Regime}

Uganda, a country with serious social and economic problems, has a leadership that is under threat from anti-government movements that oppose the now quartercentury rule of Museveni. His most recent election in 2011 was marred by allegations of fraud by the leader of the opposition, Kizza Besigye, who went to Kenya to seek medical treatment after being roughed up by Ugandan police following a protest. This assault led to riots by his supporters and those in Uganda who are in opposition to Museveni. Besigye has called for protests like the ones that overthrew former Egyptian President Hosni Mubarek in Egypt. (bbc4)

Protests are spurred by the economic reality that many Ugandan have to live with. The standard of living in Uganda is poor. There exists anger over a weakened currency, and over the ability of Ugandans to compete with Chinese business people bringing in cheaper imported products. According to Kampala native Linda SSempa "'it is hard to live now because things are too expensive.'"(bbc4) (bbc5 In fact in a 2004, article by Aili Mari Tripp, many Ugandans view the common foreign belief that Uganda is stable, democratic, and economically prosperous, as being false; the standard of living has long been a problem. (Tripp, 2004, 4)

Legitimacy is critical for a country. Without legitimacy it is difficult for the leadership of a country to guide that country in a positive direction economically or politically. (Bass, 187) In Uganda there has developed a crisis of legitimacy. Legitimacy is dependent on the judgments and perceptions of the inhabitants of the country in question. It is partially a matter "of the institutionalization of political organization." (Levy/Kpundeh, 2004, 137) In a legal and political sense, it matters if the leadership came to power through a fair and free election. Its legitimacy is also measured by how the government successfully provides for the people of a country's needs. (Levy/ Kpundeh, 2004, 187) As stated above, Uganda is having problems in that regard.

The Ugandan President, Yoweri Museveni, has been in office since overthrowing the previous government in 1986. Museveni is a skilled politician but, short of winning a free and fair election, he will need another source of legitimacy on which to base his rule. One such source is to present the government as guarantor of "Ugandan values" against one or more outside groups. 
As will be discussed in the following section, there is simmering opposition to Museveni that now seems to be boiling over. As a skillful politician, in power for twenty-five years, he is certainly aware of this undercurrent of anger in his own country.

It should be noted that Museveni has another problem. This is with regard to his age. He claims to be 68 years old but his exact birthday is not known and opposition activists have held a mock birthday celebration claiming he is 73 , which would, under the Ugandan Constitution, make him too old to stand for re-election after his current term expires. This mock birthday celebration was broken up by the Ugandan authorities. (bbc6).

With regard to democratic credentials, the history of Uganda under the Museveni regime has been lacking. According to the 1999 Human Rights Watch report Hostile to Democracy: The Movement System and Political Repression in Uganda, "organized political activity has been outlawed in Uganda for the past twelve years and the National Resistance Movement has not hesitated to use repressive measures when these legal restrictions on political activity are challenged." (HRW)

The leading National Resistance Movement or NRM has gotten around rules on parties through the "movement system" in which the NRM is not considered "a political party but as a 'movement"' (HRW Report) All Ugandans must belong to this movement whether or not they agree or disagree with it's tenets. The system was voted away in a 2005 referendum, but the Constitution of Uganda was immediately changed to abolish term limits for the office of president. In 2006, Museveni won the first multi-party election, but this election was ruled to have serious "irregularities" by the Supreme Court of Uganda which also ruled that the election results would stand anyway. (State Department) This was followed by the 2011, election which, was also marred by allegations of fraud.

Historically, leaders have often used the idea of uniting against a weak outsider, who is branded an enemy, to garner popular support. Historical examples of this include Hitler and his persecution of the Jewish people, the Czarist Russian Regime and its persecution of the Jewish People, the Communists in the former Soviet Union and their persecution of the Kulaks, and the former Senator Joseph McCarthy in the United States and his anti-Communist blacklisting. This helps the leader against this enemy out-group 
to gain legitimacy from those selected to be in the in-group. This tactic was used by leaders such as Adolf Hitler, Vladimir Lenin, Pol Pot, the North Korean Regime, Saddam Hussein as well as many other dictators from the past, who rose to power in countries that were at the time having severe problems by gaining legitimacy. In Hitler's case it was the Jews and other "untermensch," or sub-humans who were the focus, while in Lenin's case it was owners of property, whether poor, kulak, capitalist or aristocrat. Pol Pot felt that way about intellectuals; North Korea posits counter-revolutionaries, while Saddam Hussein spoke out against the Persians occupying Arab land.

In the face of the challenges to Museveni's leadership, homosexuals provide a useful target to draw attention away from his problems and towards another group for which he cares little and against which much of Ugandan society has religious or cultural antagonism. Democracy is not the only global basis for legitimacy. There are also "people's democracies" in which legitimacy is based on the idea of rule by the proletariat such as in Cuba and North Korea. Another basis for legitimacy is religious. A religious base can take the form of a specifically religious country such as the Islamic Republic of Iran. It can also take other forms. Uganda is increasingly moving in the direction of claiming religious legitimacy.

Others have noted Ugandan policy moving in this direction. Uganda's move in this direction has been highlighted by Pastor Rick Warren. Uganda has become the World's second country to be declared a "purpose-driven" country according to Pastor Warren. Therefore, Uganda is a country to which Warren has been paying a lot of attention. The idea of a purpose-driven country comes from Warren, who is the author of A Purpose Driven Life. In this book Warren describes how to live life for God. It includes five purposes including "you were planned for God's pleasure, you were planned for God's family, you were created to become like Christ, you were shaped for serving God, you were made for a mission”. (Warren)

By focusing on religious beliefs about homosexuality, benefits can accrue to the Ugandan leadership by attacking homosexuals, who as I noted provide a useful target, and who conveniently do not have much (or any) political clout. This group is an outcast group in Uganda. Museveni can be firmly entrenched in religion and it helps him to have a target with which both to divert the people's attention and to demonstrate that he is an 
effective leader - a legitimate leader, of the country and its values. His legitimacy would arise from religion and from his attacks on homosexuals. In Uganda the leader is attempting to retain legitimacy based on embracing religion and on fighting a religiously opposed out-group. If successful, this would allow Museveni to retain power without consent from the electorate in free and fair elections, it would make it possible for him to continue to rule a country where opposition can be crushed. It would give him more power over the country and its resources than a leader would wield in a truly democratic system.

\section{Cohesion: Religious Conflict}

Another serious problem that Uganda faces is a lack of cohesion. A state which is not cohesive has trouble supporting state capacity because different groups in society are all competing for resources, both material and political. This competition can cause strife within a society in question due to in-group out-group effects. The conflict can lead to violence, intra-societal hostility, and war, each of which harms state capacity. So it is important for leaders to find ways of unifying the societies under their leadership.

According to Granitz and Ward, 2001, people will share similarities in ethical reasoning with members that are in their in-group as opposed to their out-group. (Granitz/Ward, 2001, 310) It is often the case that there are sub-group in-groups within a larger group and that even within one organization there are many perceived groups. If the leadership is able to unite the society, or most of it, into a single in-group it will help the leadership establish state cohesion. (Granitz/Ward, 2001, 314-315) To achieve this unity, the leadership needs to work on an organizational and individual level in order to achieve the hierarchy's set of priorities. At an individual level, the leadership can establish moral codes in order to bring people in line; and from an organizational level these can be supplemented through rewards and punishment. (Granitz/Ward 2001, 315)

Uganda has sectarian, regional, and ethnic divisions. According to the CIA website, Uganda has a mixed religious population with $42 \%$ Protestant, $41.5 \%$ Catholic, Muslim 12.1\%, and 4\% none or other. (CIA Website) Further, no ethnic group makes up more than $20 \%$ of the total population, with the Baganda forming a plurality with $16.9 \%$ of the population. (CIA Website) As such, the country's leadership needs to find ways of 
unifying the many smaller groups that already have their own in-group interests into a cohesive entity and of creating a larger Ugandan in-group consciousness.

Muslims are angry at the way they are treated in the Ugandan political order. According to an article in the Ugandan newspaper The Daily Monitor their anger concerns their representation in the Ugandan Cabinet. Muslims who follow Mufti Sheikh Zubair Kayongo have called on their followers to "shun all government functions, over marginalization." (Otage) This comes from the belief that Muslims have not been offered enough ministerial positions in Uganda. Further, there is anger and a feeling of underrepresentation in other bodies such as commissions and statutory bodies. Islam, an important group in Uganda, is anti-homosexual in its opinions, and would support a government that was working to oppose homosexuality. This the government of Museveni has done. There thus exists evidence of a leader on shaky political ground with his Muslim population.

There are also Christian groups in Uganda, split between Protestants and Catholics. Both of these groups strongly oppose homosexuality. The Catholic Church under Popes John Paul II and Benedict XVI has spoken out against homosexuality and has informed its followers to oppose homosexuality. John Paul II told Catholics that homosexuality was sinful, as has Benedict XVI. When one looks at the population of Protestants in Uganda, the Protestant Churches of that country have been forceful in arguing that the ordination of gay Bishops is not acceptable. They have also strongly opposed homosexuality as has been covered elsewhere in this document.

In Uganda there is broad agreement among believers in the major religious groups that homosexuals are a group who should be oppressed. This belief runs the gamut of Protestants, Catholics, and Muslims in Uganda. Indeed, there was discrimination against homosexuals before there was any significant attempt by foreign Christian groups to effect policy change in Uganda. But it was only after the foreign groups began investing heavily in anti-homosexual programs that the dislike was consolidated into MP David Bahati's attempts change official policy so that the government would execute homosexuals as a matter of state policy.

Much as is the case with legitimacy, described above, homophobia can be used as glue by the leadership in order to pull together disparate elements of Uganda's religious 
makeup. Homosexuals have few resources in Uganda with which to defend themselves. Conflict between Muslims and Christians can be subliminated through attacks on homosexuals. This has provided fertile ground for the foreign Christian groups to plant a more militant version of homophobia in Ugandan society. As an intelligent leader of a country Museveni must know this tried and true method of creating a target to distract the people's attention. The attacks against homosexuality perpetrated by Scott Lively and others were perfectly placed to cause the Ugandan Government to start moving in an antihomosexual direction as will be described below in the section on Foreign Christian Effort.

\section{Cohesion: Exploiting A Common Enemy}

In this section I demonstrate why, given the problems that Uganda is having with its state capacity, homosexuals are a useful group on which to focus opposition and this does go beyond religion. As with the discussion of legitimacy, one of the ways to create societal cohesion amongst the powerful societal groups is to unite the people against an easily created and socially weak target group. It is preferable for this target group to be within the country, to avoid clashes with an external power that can defend itself against attacks from the Ugandan government. As observed above, homosexuals fit this requirement for such a target in Uganda.

Homosexuals form a nearly perfect target for the main Ugandan religions to unite against. In Uganda, Islam is strongly opposed to homosexuality. According to many of the supporters of Islamic Law or Shari' a, homosexuality is an abomination, and the death penalty should be applied. Their opposition to homosexuality is religion-based. (Helie, 2004, 120) ${ }^{1}$ According to some opponents of homosexuality "the Qu'ran clearly states that homosexuality is unnatural, ignorant, criminal, and corrupt." (Helie, 122) In 2007, Mufti Sheikh Ramathan Shaban Mubajje stated that homosexuals should be rounded up and placed on an island in Lake Victoria; if they died then Uganda would be rid of homosexuals. In a quote he stated that when he talked to President Museveni "I asked President Museveni to get us an island on Lake Victoria and we take these homosexuals

\footnotetext{
${ }^{1}$ It must also be stated that not all Muslims believe this. Some argue that the opposition by some Muslims to homosexuality is cultural rather than religiously based. (Heili, 122)
} 
and they die out there," (Bagala, All Africa) It should be noted that this predates the attempt to give homosexuals the death penalty. That effort only happened after the intensive foreign Christian attempts. This request by the Mufti was not the catalyst for the attempted law but that the law could help unify the country under Museveni and his political cadre.

Further, this focus on homosexuals has been strengthened by the attention given to them by foreign Christian groups. To be clear, homophobia and homophobic policies pre-date the attempts by foreign Christian groups to promote these beliefs to Africa. Many Africans view homosexuality as "un-African" and as a disease imported by Europeans. Africans were supposed to comport to notions of fertility and this was an obligation for both sexes. (Epprecht, 1998, 632, 634) Homosexuality is, however, attested to in Africa before the advent of Europeans and the Christianization of much of Sub-Saharan Africa. (Epprecht, 1998, 631)

In the modern era there are also domestic forces working to create homophobic policies in Africa. Martin Ssempa a Ugandan pastor claims to be an AIDS activist. (Ssempa, Ssempa's Website) He advocated the marriage-and-abstinence approach to combating AIDS, and has burned condoms in the name of Christ. In fact he has shown homosexual pornography to his church; and has claimed that homosexuals like to eat feces, showing such a video to those assembled. (Ssempa, Youtube)

According to the social-psychological literature, people make strong distinctions between those they consider in their in-group and those that are considered to be in their out-group. It is much easier for someone to be turned against an outsider. As such, people who are in an out-group from most of society are much more easily turned into targets for societal anger especially if the out-group is seen to be harming the interests and well being of the members of the in-group, perceived as those who "matter". Politicians realize this, as does the Ugandan leadership. Given this it can be expedient for a leader to pick a group that can easily be considered "out" by the majority of society. When a group of Westerners claiming to be the protectors of African culture arrived in Uganda in 2009, they set the stage for the increase in anti-gay violence and anti-gay policy attempts by members of the Ugandan leadership. 


\section{Education}

As discussed in the chapter on South Africa, education is important for people's ability to think critically and gather information for themselves. As said there, it is easier for foreign Christian groups to influence the people of a particular country if it has a lower education level and literacy rate than if it has a higher level. This can be seen here in our second case study country of Uganda, whose education levels are relatively low when compared with South Africa.

Education in Uganda is poor, and has been getting worse. The country has spent only $2 \%$ of its 2000 budget on education, down from $3 \%$ in 1995 , as a result of instability. The average secondary school attendance now stands at a mere $15 \%$ for women and 16\% for men. (UnicefWebsite2) As stated earlier, if a person can not read then that person is much more at the mercy of those who supply information to them than if they can gather information for themselves. If they can get their own information, they are more likely able to form their own opinions. Without the ability to read, a person can not open up a newspaper or magazine, or search a great deal of the internet in an effort to find differing sources of information. In Uganda the literacy rate, as of 2007, is only $66.8 \%$ meaning about $31 \%$ of the population can not gain information for themselves that they would have been able to get if they could read. In Uganda, school attendance is compulsory for ages six through twelve a total of six years. This is $75 \%$ of the time that South Africa mandates its children to attend school.

Total secondary school attendance is very low when compared with South African levels. In Uganda, secondary school attendance is a low $16 \%$ for males and $15 \%$ for females during the period from 2005-2009. (UNICEF 4) With these levels, much of the population does not have the education to think critically about subjects and would therefore be much more likely to be swayed by the rhetoric of the foreign Christian groups and their already-influenced countrymen in determining their opinions on such matters as gay rights and abortion.

We can see that on all measures, literacy rate, years of school mandated, and secondary school attendance for both males and females. Uganda ranks consistently lower than South Africa. This is what would be expected. And it supports our thesis that the country where the state capacity with regards to education is lower (Uganda) is 
influenced by Christian supported policy much more than does the country of South Africa where there is less influence with regards to policy.

\section{Foreign Christian Effort}

\section{Outreach: Visits to Leaders and People}

Given this backdrop of increasing pressure on the Ugandan leadership; impetus for using Homosexuals as a group to unite against was spurred forward by the activity of outside Christian groups. Their activities are the subject of this section. In Africa, conservative churches have worked with political and religious leaders to encourage homophobia. These conservative churches had used wedge issues such as homosexuality to garner support. (Kaoma, 6) To many Africans the attack on homosexuality is more of an attack on Western values imposing such a "'Western Agenda"” on Africa. (Kaoma, 8) There has been a great deal of effort to spread and intensify anti-gay beliefs in this country by American evangelicals who are targeting Uganda. And here is the direct evidence in Uganda regarding efforts by foreign Christian groups to influence Ugandan policy regarding homosexuals that is presented here.

Rick Warren of the Saddleback Church, which is based in California, and has eight locations around Southern California, as well as one in Afghanistan, (Saddleback Website) has had a close working relationship with Martin Ssempa, a Ugandan pastor and founder of the Makerere Church in Uganda. Ssempa is also a leading advocate of recent proposed legislation in Uganda to punish Homosexuals with the death penalty. (Blumenthal, DailyBeast.Com) Ssempa's activities were discussed in the section on domestic factors.

Ssempa and Warren have had a close association in the past. Ssempa has visited Warren's church numerous times, although Rick Warren has distanced himself from Ssempa more recently saying in a statement released in 2007 that Ssempa's opinions were at odds with Warren's views. (Warren Statement) He has, however, refused to publicly condemn the proposed death penalty legislation. On Meet the Press Warren argued a neutral position on the proposed legislation: "As a pastor, my job is to encourage, to support. I never take sides."(Huffington Post) However, he went on to condemn abortion as genocide, which contradicts this claim of neutrality and shows that 
when he does oppose something does take sides. (Huffington Post) Later, after a firestorm of criticism, he did he eventually distance himself from the legislation publicly. (Coleman, NPR)

Ssempa, a strong proponent of anti-gay legislation in Uganda, has been in close personal contact with Warren another anti-gay preacher. While the flow of ideas from Warren to Ssempa may not provide conclusive proof of the theory that foreign Christian groups can amplify their influence by directly supporting a local ally, it is strongly suggestive in this case in which Warren's stance was followed by Ssempa amplification.

Another foreign Christian activist with an association to Uganda is Scott Lively. He is the author of The Pink Swastika, a book that blames homosexuals for the Holocaust perpetrated by the Nazis during World War II. In a speech he made to Ugandans during a 2009, anti-homosexual conference in Uganda, Scott Lively claimed that homosexual people were responsible for the Holocaust and that these people "are animalistic men that want to hurt other people. You know there is no mercy in them." (Burroway, Lively Speech 1) He goes on to say that the "Rwandan stuff probably involved these guys" (Burroway, Lively Speech1) Discussing the people homosexuals attempt to seduce, he argues that "male homosexuality has historically been not adult to adult. It's been adult to teenager. It's called pederasty." (Lively Speech 1) He concludes "they are looking for other people to be able to prey upon." (Lively Speech 1) A compatriot from Africa then announces "they want the children." (Lively Speech 1) At the same time he led his antihomosexual conference he was also invited to speak and did speak before the Ugandan Parliament. (Rice) It should be noted that Lively has attempted to backpedal on the death penalty portion of the bill.

In fact Member of the Ugandan Parliament David Bahati (discussed above in this chapter) has used strikingly similar language in support of his death penalty bill. (Change.org) The fact that Lively's speech was followed shortly by the introduction by Ugandan MP Bahati of the death penalty bill is again not conclusive proof, but provides strong support for the idea of a connection and mixing between anti-homosexual foreign Christian forces such as Lively and those who make policy in Uganda such as this Ugandan parliamentarian. It was shortly after the conference that Ugandan MP David Bahati introduced the death penalty bill that I discussed earlier. The fact that very similar 
language, such as likening Homosexuals to Pedophiles, was used by both Bahati and Lively adds additional strength to the hypothesis of a connection.

There is also evidence of Bahati's connection to other foreign supporters. In an interview on NPR, Jeff Sharlet, journalist and author of the book The Family: The Secret Fundamentalism At the Heart of American Power, argues that Bahati has a connection to a United States based group of socially conservative Christian people called "the Family." (NPR Interview) He went undercover with "the Family" to uncover their activities. The Family is an organization of right wing Christians that have members in positions of power in both the United States such as Senators and former Senators Jim DeMint, James Inhofe, Tom Coburn, John Thune, Mike Enzi, and Strom Thurmond who gave the Family confidential information about legislation. (Sharlet, 18,19) It also has presence around the world, including in Uganda. Sharlet states that this group of American Christians fund Bahati and Bahati is one of "the Family's" main people in Uganda. (Bartholomew/Barthsnotes) In an interview on National Public Radio, Sharlet states clearly that Bahati is in fact a member of "the Family." (NPR Interview) In an interview with MSNBC's Rachel Maddow, Jeff Sharlet states that David Bahati is a member of the Family. Further, Museveni is described as having been recruited by the Family after taking power in 1986. (Rachel Maddow Show)

Museveni has been anti-homosexual with his support for the bill. He has at the very least been passively supporting the bill while his fellow party member David Bahati pushes it forward. He has claimed that homosexuality is being imposed on the countries of Africa by outsiders and that it Africans should unite against this foreign influence.

Bahati runs the prayer breakfasts of "the Family" as well as overseeing a program for African students in an attempt to create future leaders for Africa. Further, "the Family" has attempted to recruit Yoweri Museveni, the President of Uganda, who they identified in 1986, as being potentially useful. A Family representative worked with Museveni to create a prayer breakfast system in Uganda that is similar to the one in the United States. (Interviewer, Goss, NPR.Com) This connection between Bahati, Museveni and foreign Christian groups demonstrates another path by which these groups are attempting to influence policy in Uganda. 


\section{Exploitation of Aid Channels: United States Influence}

This section is here to elucidate how a Christian group or activist does not need to set foot in, or directly aid the target country, but can influence a powerful country to do its work for them. The United States ranks very high on the Human Development Index and has an influence over countries that rank much lower on that scale. Countries that are lower on that scale often rely on those higher up for much needed financial support. When influenced by Christian groups within the United States the U.S. can have a proChristian impact on the policy of the developing world. Christian groups from the United States have exerted pressure to make U.S. foreign policy match the goals of these Christians. There has been an effect on abortion and in related reproductive health issues such as AIDS funding and family planning in general.

There has been a re-emphasis in regards to the type of social aid coming from the United States. This re-emphasis in exemplified by as President George Bush's "President's Emergency Plan For AIDS Relief." This plan was in operation during the administration of President George W. Bush, who is noted for his support of right-wing causes. President Bush's plan de-emphasized safe sex approaches with funding that stressed abstinence and other approaches more in line with those advocated by extreme Christian organizations.

This plan basically replaced scientifically backed anti-AIDS funding, such as funding that supports the use of condoms, with more Christian supported funding for abstinence. Condom use has been demonstrated to work. One early study done of gay male cohorts who used condoms demonstrated that in those cohorts the rate of new transmission of HIV, the virus that causes AIDS, declined greatly. (Rotello, 1998, 112/113) In Bush's administration, with a Republican controlled Congress, funds earmarked for abstinence have increased from one third of the total to two thirds. (Sussman, Women's News) There has been a shift from encouraging use of condoms as a major tool in the fight against AIDS to removing mention of condoms from the Ugandan anti-AIDS slogan that had been promoted in the 1990's - "Abstain, be faithful, use condoms." (Human Rights Watch) The curtailment of those methods for fighting the spread of AIDS found unacceptable to Christian groups became more noticeable after the inauguration of the Second Bush Administration. In 2001, the government of Uganda 
launched an American funded program called the Presidential Initiative on AIDS Strategy for Communication to Youth which focused on abstinence or PIASCY. (Cohen/Tate, 2006, 175) Then, in 2004, the Ugandan AIDS Commission published a document entitled "Abstinence and Being Faithful" which suggested implementing such abstinence programs that have failed in many U.S. States. (Cohen/Tate, 2006, 175) The United States is critical to Uganda's anti-AIDS effort: "As the largest single donor to HIV-AIDS programs in Uganda, the United States is using its unparalleled influence to export abstinence-only programs that have proven to be an abject failure in its own country." (Cohen/Tate, 2006, 177) The United States does provide other aid including much needed assistance for important anti-retroviral medication. The number of people receiving anti-retrovirals has gone up from 10,000 to about 141,000. (McKenzie/ Swails/CNN) There was more emphasis put on abstinence programs by the Bush Administration in 2003, when he pledged about seven billion dollars for AIDS in the countries most in need through his President's Emergency Plan for AIDS Relief or PEPFAR. Uganda received ninety-one million in PEPFAR funding. (Avert.Org) In fact, eight million of these ninety-one million dollars was budgeted for behavior change and abstinence. Of this eight million, three million dollars was spent on the Presidential Initiative on AIDS Strategy to Youth or PIASCY, (Cohen/Tate, 2006, 175) Religious organizations vetoed the inclusion of sexually based materials in PIASCY. Scientific evidence was replaced with moral proscriptions.

What is interesting is that the policy of removing safe sex from PIASCY, and the vetoes, started to be enacted shortly after a USAID advisor from the United States was placed in the Ugandan Ministry of Education that oversaw the program in Uganda. The new abstinence efforts actually attacked condom use in Uganda as unsafe. (Cohen/Tate, 2006, 175) The first lady of Uganda Janet Museveni has sponsored a group of new billboards that promote abstinence. These have largely replaced the old ones that promoted condoms. This is largely due to the United States' funding decisions. "Washington will fund anything for abstinence. "' (Klink, 45) This is according to Fred Wabwire-Mangen who is a MD and a professor at Uganda's Institute for Public Health. (Klink, 45) This provides another example in which money coming from Christian 
influenced actors from outside of the developing world has influence over developing world policy.

Channels of influence can go through educational establishments that are selfdescribed as conservative. For example, aid from USAID goes to the Uganda Christian University. This University openly discriminates against people who are in the Lesbian Gay Bisexual Transgender community and even discriminates against people who hold differing religious beliefs. About 25\%, from various sources from USAID is funneled through Diane Stanton, the wife of right wing Christian Reverend James Stanton and then on to the Uganda Christian University. (Kaoma, 2009, 12 )

The connections documented above demonstrate the connection between an American foreign policy influenced by Christian groups and a change in social policy in the country receiving the American funds.

In relation to abortion, as the "gag rule" described in the South African case study section not only bans funding to groups that perform abortion but even to groups that just talk about it. This rule has been in effect during the Republican Reagan, first Bush, and second Bush Administrations. These are the administrations that are more closely supported by Christian groups. In fact Pat Robertson of the 700 Club had been a presidential candidate in the Republican Party in the 1988 election cycle. The "gag rule" has had an effect on Uganda as well. Whereas South Africa has gone on to liberalize its abortion laws, Uganda has not done so, and abortion remains illegal there, except in the case of rape or if the mother's life is in danger. According to Jenna Klink, unsafe abortions are the cause of one-third of all maternity-related deaths. The policy has not changed and the de-facto policy is that physicians do not want to talk about abortion because it is a crime in Uganda. (Klink, 2006, 43)

Uganda is noticing the effects of the Gag Rule. Since its inception the Gag Rule has prevented clinics and health care providers from discussing or providing abortions for people in that country. The atmosphere in Uganda is such that public debate over the issue of abortion is discouraged. Further the concept of legalized abortion does not receive a great deal of coverage in the Ugandan news media. Public debate is critical for the law in Uganda to change and for abortion to become legal. (Klink, 43/44) Klink argues that George W. Bush's foreign policy with regards to abortion "contributes to the 
silence that surrounds abortion in Uganda." (Klink, 44) Non governmental organizations that would like to petition for changes in the laws of Uganda feel unable to do so due to the fact that funding from the United States would then be stripped from them. (Klink, 44)

Although it is only one of several factors involved in keeping abortion illegal in Uganda, the fact that those who might provide abortions or advocate for a change in the law of Uganda are unable to promote such a change dovetails with the other influences, such as Christian groups already in Uganda that are strongly opposed abortion and safe sex policies help to keep abortion a crime in Uganda and harm the Ugandan AIDS effort. As stated, there has been no attempted policy change to liberalize abortion laws in Uganda. Further AIDS policy has become even more conservative.

\section{$\underline{\text { Policy Effects }}$}

\section{Attempts to Change Homosexual Policies}

We have so far discussed both the problems that Uganda is having with state capacity and the attempted foreign Christian penetration. Now attention must be drawn to effects on policy in Uganda, and its current state with regards to homosexual rights. When Uganda became independent of the United Kingdom in 1963; Uganda retained the inherited laws regarding homosexuality that existed under the United Kingdom's colonial administration and thus Uganda's laws criminalize homosexuality. This law was a leftover from former colonial rule and thus can not be considered, as far as this document is concerned, to be evidence of foreign Christian penetration.

Two facts must now be noted. The first is the fact that the law against homosexuality was never rescinded as it was in some other countries that became independent from European powers. The second is that there have been serious attempts to change Ugandan government policy that follow more recent attempted Christian penetrations. These policy changes are intended to make lives harder for homosexuals in Uganda.

As I will shortly discuss, one major action taken by the Ugandan government in conformance with policies urged on them by foreign Christian connections was the introduction of a bill to establish the death penalty for homosexual conduct. Although 
introduced as a private members bill by parliamentarian David Bahati of the ruling National Resistance Movement, it has consequences far beyond a single thread of influence, and it discussed here so that it may be referenced in several contexts. The bill has caused outrage among much of the Western world and many human rights organizations. Sweden, one of Uganda's major donor states, has threatened to withdraw funding for Uganda. (BBC7) Thus, it should be noted that, although there is an attempt by foreign Christian groups to influence policy, there are also international actors who attempt to influence countries to enact policy that are more liberal with respect to homosexuality.

The above buttresses the argument that less functional states are more open to foreign Christian effort. If the foreign groups that oppose bills such as the Bahati bill can influence a less functional country with cash diplomacy in a direction that the aid recipient otherwise might oppose. It should be even easier to influence less functional states to craft policy in a direction that their governments do not find objectionable

This legislation would include "Aggravated Defilement." This activity is defined to mean any of three things: 1: homosexual relations with someone under eighteen years of age, 2: homosexual acts when one has HIV/AIDS, and 3: serial homosexual acts i.e. committing homosexual behavior more than once. Any of these three behaviors would be punishable by the death penalty. The law then goes further, it would ban the promotion of homosexuality, and it would subject a Ugandan in a gay marriage to life in prison. Further, it placed a mandate on the Ugandan people to turn a homosexual in to the Ugandan government within twenty four-hours of discovery of that person's homosexuality. The law would take precedence over international obligations that Uganda may have become party to. (Amnesty International Report) Finally, the law would apply to All Ugandans whether they lived in another country with differing laws or not.

Although the Family is attempting to deny responsibility for the bill and have stated they are not responsible, according to Sharlet "there's a sense in which they built the gun, which was this institutional idea of government being decided by small groups of elite leaders like Bahati, getting together and trying to conform government to their 
idea of Biblical law. And this is what their American benefactors wanted them to do." (NPR)

This measure was seriously considered by the Ugandan government and was only allowed to die in Parliament after a firestorm of criticism from foreign donor countries such as Sweden. Thus it does seem like there was a serious attempt not only to prevent rescission of previous anti-homosexual laws, but in fact to strengthen the antihomosexual laws already of the books in Uganda.

Not surprisingly in other areas of gay rights Uganda ranks as more restrictive. It has no provisions for the prohibition of discrimination, one can incite hatred against gays, there are no marriage or partnership rights and gays can not adopt. (ILGA 2010)

\section{Abortion}

According to the United Nations Uganda will allow abortion only for the health or life of the mother. (United Nations Uganda abortion Policy) There have been no serious attempts at liberalizing abortion law. In fact quite the opposite has occurred. According to Dr. James Nsaba Butero the Ugandan Ethics and Integrity Minister in 2008, "as a government we cannot push for such legislation [allowing abortion].” (Womensphere) Minister Butero went on to say that abortion "is against our cherished cultural norms and the doctrines of God." (Womensphere) He also claimed abortion was an evil. (Womensphere) This legislation was in response to suggestions from some doctors in the area ravaged by the Lord's resistance army to help women who have been raped by the LRA. The laws of Uganda have remained against the free practice of abortion.

\section{Resource Starvation}

This section illuminates how lack of Ugandan state capacity trickles down to be a root cause of homosexual weakness in Uganda. In this society, which is already impoverished, it is evident that such a persecuted group would have only a tiny sliver of the already meager resources of Uganda with which to defend themselves, in contrast to the socially prominent government and religious groups attacking them. Homosexuals in Uganda, like most others in, the country have few resources with which to counter the anti-homosexual power structure. 
Due to the impoverished nature of the country and to their persecution, Ugandan homosexuals, by definition, lack needed funds and organization. In fact, many interest groups that are opposed to government policy have problems operating in Uganda. Recently, a radio station that suggested toleration of homosexuals was shut down by the government. In countries with higher levels of state capacity, homosexuals may have resources to counter homophobic groups and government. In the United States and Europe, as well as in some parts of Latin America, pro-homosexual groups are, if not well-funded, often funded well enough to get their message out to the general population. Further, there are more well-functioning organizations in countries with higher state capacity that are willing to help homosexuals gain rights which they had previously been denied.

In countries with lower levels of state capacity it is harder for minority groups to gain the funding and organization they need in order to successfully fight for their rights. Members of powerful groups in those countries can, by definition, have their voices heard, even if those countries are impoverished, while weaker groups have more difficulty. This is the case with Uganda.

Although certain interest groups do exist, such as Sexual Minorities Uganda or SMUG, which attempts to co-ordinate homosexual rights activities in Uganda, their power is very limited. They monitor events and attempt to distribute information but much of this is to no effect, as evidenced by the fact that one of the most outspoken leaders of SMUG, David Kato, was killed. When asked about the death Giles Huhame the editor of Uganda's Rolling Stone (not the famous music magazine) stated what he felt about organizations that "promote" homosexuality. "We want the government to hang people who promote homosexuality, not for the public to attack them." (BBC) For all of the above reasons it is very difficult for homosexuals to organize in that society. Lack of state capacity, insofar as it is defined in this document, makes it very hard for homosexuals to gain a positive public face. When summing the effects of government actions, lack of funds, and lack of government protection, the structure of the country leads to the result that homosexual organizations have a hard time forming and then operating inside Uganda. 
Things seem set to become more difficult for homosexuals, as David Bahati plans to re-introduce his legislation without the death penalty clause. The newly proposed bill would, if enacted, still make illegal the promotion of homosexuality. This definition would not just mean that groups could not argue for equal rights, it would go as far as to ban funding to groups who serve Lesbian and Gay people. This would have the effect of harming the provision of AIDS treatment and prevention as it would make the work of those who are serving HIV victims all but impossible under the new law. (LATIMES.Com) (ADL.COM)

\section{$\underline{\text { Causal Mechanisms }}$}

In the case of Uganda there are two causal mechanisms that are important in terms of how state capacity relates to the way countries with lower state capacity are influenced by foreign Christian groups more so than those with higher state capacity. These are: a) foreign aid and b) leadership vulnerability.

The causal mechanism in this the area of foreign aid is the desire by the leaders to receive the foreign aid money and then implementing their desires in the form of policy that they believe will help get them that foreign aid. Uganda is a country with few resources and an AIDS problem. Influenced by internal groups, the United States has emphasized abstinence and pro-life political views in much of its foreign aid. The specific mechanism is that Uganda's leadership wants foreign aid and has chosen to adjust its policies regarding safe sex to dovetail with the emphasis put on abstinence by the United States. Policy in Uganda has been influenced through several foreign aid mechanisms:

- the Presidential Initiative on AIDS Strategy for Communication

○ the "Abstinence and Being Faithful"

$\circ$ the billboard program promoting abstinence

- the Uganda Christian University, which openly discriminates against people in the Lesbian Gay Bisexual Transgender community

- family planning aid from the United States implementing the "gag rule"

The second causal mechanism is a leader's need to maintain power. Leaders who want to maintain power will institute policies and activities that they feel will allow them to maintain their authority. The mechanism then is the implementation of activities that 
they think will lead to a desired result i.e. the maintenance of power. The Ugandan leadership is in a position of power over a low state capacity country and, as a result, has to counteract the effects of the lack of legitimacy and cohesion in Uganda. One way of doing this is to use support from others who have similar views. The leadership sees implementation of the policies and goals of the foreign Christian groups as a match for the leadership's goals of staying in power. Attacking homosexuals as the foreign Christian groups advise dovetails with the desire of the Museveni administration to have a group for society to unite against and gives the regime legitimacy as the defender of "true" Ugandan values. The Christian groups have utilized Yoweri Museveni's vulnerability by supporting his strategy in several ways:

- homosexuals provide a useful target to draw attention away from his problems and those of other elements of Uganda's leadership and direct it towards another group. Impetus for using homosexuals as a group to unite against is supported by the activity of outside Christian groups

- Rick Warren of the Saddleback Church, based in California, has had a close working relationship with Martin Ssempa, a Ugandan pastor and founder of the Makerere Church in Uganda

- close cooperation and "speech borrowing" between Scott Livel, the American activist, and David Bahati, a Member of the Ugandan Parliament

- similar connections between Bahati and the United States based group called "the Family."

Another way of maintaining power in a country with low state capacity is to exploit the lack of education by controlling information channels. These factors are the important in Uganda, and exploited in several ways:

- exploitation of the effects of the "gag rule" to promote resource starvation of groups promoting alternate views and candidates.

- the billboard program promoting abstinence

- the Uganda Christian University's open discrimination against people in the Lesbian Gay Bisexual Transgender community 


\section{$\underline{\text { Conclusions }}$}

The Ugandan case study made several points. It demonstrated that Uganda was lacking in the key areas of state capacity: legitimacy, cohesion, and education. Uganda is lacking in these and the Ugandan Government has felt the need to use a scapegoat group in an attempt to give itself legitimacy and cohesion. The Ugandan case study section also showed that Uganda was the recipient of right-wing foreign Christian efforts. These efforts were directed towards stripping from homosexuals the few rights that they already had in Uganda. Finally, the section showed that there was meaningful attempted policy change in Uganda. This change was in a direction that was antagonistic to the rights of homosexuals and more in line with the desires of right-wing Foreign Christian Groups. From this, it is evident that issues of weakened state capacity allowed foreign Christian efforts to have a meaningful effect on policy change in Uganda. The foreign and domestic independent variables worked together in this case to the advantage of the foreign Christian groups. The lack of legitimacy, cohesion, and education provided fertile ground for foreign Christian groups to influence government leaders by providing them with much needed help in terms of legitimacy and cohesion and making aid much more necessary than in South Africa 


\section{CHAPTER 5: LATIN AMERICAN CASE STUDIES}

\section{DISCUSSION OF FOREIGN CHRISTIAN EFFORT}

\section{AGAINST HOMOSEXUALITY}

This section discusses the connections between foreign Christian organizations and the relevant domestic policies in Latin America. Much of the foreign Christian effort in Latin America with regards to homosexuality comes from the Catholic Church, based in the Vatican. Although the religion is shared, this Christian effort is considered foreign as it takes direction from Rome not from inside of the host country.

The Latin America that is known today is partially a product of Spain's culture as it existed during the colonial times. In both Europe and Latin America there existed an alliance between the state and the Roman Catholic Church, an alliance that was transferred to the Spanish colonies in Latin America. (Fitzgibbon, 1960, 49) The Catholic Church has become one of the pillars of Latin American society and has for much of its history been a conservative force in favor of the social status quo. (Fitzgibbon, 1960, 54) Catholicism is not the only major religion in Latin America. Protestantism has been growing in Latin America. Guatemala, a case study country, has been particularly influenced by Protestantism as will be described later in this section.

\section{$\underline{\text { Overview of Catholic Indigenousness }}$}

\section{A discussion of how Catholicism is foreign}

This document covers foreign Christian influence in the developing world's domestic social policy. The Catholic Church is the predominant religion in Argentina. It is in fact an overwhelmingly Catholic country in terms of its faith. In Argentina the majority of the population professes the Catholic Faith. It would seem therefore that Catholicism is an indigenous belief in Argentina. There therefore needs to be a discussion as to why Catholicism is a foreign and not a domestic Christian organization.

The first argument is geographic. The Catholic Church is a hierarchical religion based outside of Latin America in Rome. This is geographically outside of the area of study, in this case Latin America. The Church is now global in its reach, controlled by Cardinals from around the world. Cardinals are effectively internationally oriented 
individuals even though they control dioceses in specific countries. Cardinals are known serve in the Vatican's diplomatic corps. This includes Argentine Leonardo Sandri who is the Cardinal of Santi Biagio e Carlo ai Cantiari in Rome. He served as the Papel Legate in both Mexico and in Venezuala. He also serves as the Cardinal Prefect of the Congregation for Oriental Churches part of the Roman Curia. (Catholic Hierarchy.Org) These cardinals develop policy documents and elect the Popes who have the final say on Church policy. It can not therefore be considered indigenous to any one area.

The next argument is that historically, just because a country's populace is overwhelmingly Catholic, that does not mean that it views the Catholic Church to be a domestic political force. Indigenous Catholics often follow leaders from the nondomestic Church based outside of home country rather then domestic leaders. Historically, much of Europe was Catholic. Nevertheless this did not stop indigenous secular leaders from fighting the influence of Catholicism in their countries. These disputes often involved money sent from the home country to Rome, the appointments of local Catholic leaders such as Bishops, and differences between secular leaders and the Catholic Church over policy. England was a devoutly Catholic country whose King Henry VIII was declared Defender of the Faith by the Pope. This did not stop the King from viewing the Church as an outsider when they clashed over policy, in this case the divorce of the King from his first wife, Catherine of Aragon.

In Latin America there have been revolutions against conservative elements of society that were allied with the Catholic Church. These revolutions, like that in Mexico, led to the weakening of Church power in the home country.

The Catholic Church is hierarchical and multi-national. That it is hierarchical is evidenced by the strict power hierarchy in the Church. Unlike some other faiths such as Islam which has not had a Caliph since the end of World War I; the Church has a recognized leadership with supreme power invested in the Bishop of Rome, otherwise known as the Pope. This power structure is independent of the power structures of host countries, including those in Latin America. Bishops do not take orders from the presidents in Latin America; they take their orders from Rome.

The following section about Latin America will demonstrate evidence of the Catholic Church leaders in Latin America taking their social lead from the Vatican and 
not from the domestic power structure. It will demonstrate that having gotten their cues from Rome, the Bishops then attempt to influence the policy of the host country in the direction of the beliefs of the Church.

\section{Catholic Belief on Homosexuality}

Pope John Paul II, leader of the Catholic Church from 1979-2005, strongly opposed acceptance for homosexuals in the Catholic world, including in Latin America. As Pope, he made his first statement on the matter of homosexuality in 1986. John Paul II, in a letter argued that homosexuality, as such is a "moral evil" the inclination towards homosexuality should be considered a disorder, and that this lifestyle is not acceptable. In his 2005 book, Memory and Identity, he referred to homosexuality as an "Ideology of Evil." (Cline, About.Com)

Pope John Paul II was succeeded by Cardinal Ratzinger, a very conservative cardinal, as Pope Benedict XVI. According to John Allen, although the new Pope has been more circumspect and less heavy handed in his leadership than many more liberal elements of the Catholic Church feared he would be, the leadership of the Church has been cracking down on liberal dissent. Benedict XVI initiated several of conservative actions. The more liberal Leadership Conference for Women Religious has been attacked for its stance on women priests and homosexuality, being referred to as being infiltrated by "radical feminists." Further, he personally attacked 300 Austrian deacons and priests for their stance on the ordination of women and celibacy. (Allen) He has also spoken out strongly against homosexual rights in the world. He argued, during his 2007 trip to Latin America, that sex outside of marriage was wrong, supported the sanctity of marriage, and criticized legal reforms for homosexuals and their relationships. (NowPublic.Com)

\section{Foreign Role in the Latin American Abortion Debate}

On January 22, 1999 Pope John Paul II arrived in Mexico. Earlier that month Mexican President-Elect Vincente Fox had declared that in cases where a women's life is in danger she should be allowed to abort the fetus. The Pope stated "May no Mexican dare to harm the precious and sacred gift of life in the maternal womb." (Lamas, 2000,

11) By emphasizing this point in this speech targeted to his audience in Mexico, the 
Pope reminded the political elite in Mexico that the Church held great power in Mexico, and that the laws on abortion should not be liberalized. (Lamas, 2000, 11)

In Argentina, a case study country, the Catholic Church also has influence. Former President Menem followed the Church's line on abortion by supporting campaigns that were anti-choice. (Bellucci, 103) "The Catholic Church has strongly marked the prevailing ideological climate making it difficult to discuss sexual and reproductive rights and influencing the outlook of both state and society."' (Bellucci, 1997, 103) These incidents in Mexico and Argentina simply point out evidence of attempted influence, influence that in this case is aimed at a developing country. They are not meant to argue that the countries involved are non-functional or functional.

The Pontificate of Pope Benedict XVI has been as staunchly opposed to abortion as his predecessor's. On his way to his 2007 trip to Brazil, Pope Benedict stated that politicians in Mexico City who favored the legalization of abortion could risk excommunication. According to the Pope excommunication "'is allowed by Cannon (Church) law which says that the killing of an innocent child is incompatible with receiving communion." (Pullella, Reuters.Com) Thus, whatever the moral inclinations of Catholics, non-domestic influence by the Church hierarchy was placed upon the domestic community.

Once in Brazil, the Pope continued his anti-abortion message. He stated that he is "certain the bishops will reinforce "the promotion of respect for life from the moment of conception to natural death as an integral requirement of human nature" (MSNBC.Com3) Abortion is one of the key areas in which external forces are trying to influence social policy in Latin America.

\section{Latin American Adventures}

In addition to direct influence by religious organization, Latin America has also been the subject of pressure by Christian influenced foreign governments, particularly the United States under the Reagan Administration. The period around 1980, was very important for the development of the Religious Right's expansion in terms of foreign adventures in Latin America. (Marishane, 1991, 79) "One of the hallmarks of the Reagan era was the increasing 'privatization' of U.S. foreign policy" (Diamond, 1989, 161) The Christian Right was a major player in this. (Diamond, 1989, 161) The 
administration also seemed to target areas with a "lack of cohesion." (Marishane, 1991, 79) According to Richard Bissell, a former chief of the CIA, the less-developed world presents good opportunities for pro-U.S. propaganda due to the fact that "there is a diffusion of power in much of that world." (Marishane, 1991, 79-80) In Nicaragua and Guatemala, the Christian right's anti-communist efforts on Latin America were used as tools of United States foreign policy. Several examples of the Christian effort by foreign right-wing Christian Groups in this way follow.

There was a private network supplying the Contras in Nicaragua in the 1980's. The United States had been forbidden by its own laws from helping the rebel Contra movement. The government of Nicaragua was, at that time, controlled by the pro-Soviet Sandinista regime, and the staunchly anti-communist Reagan administration was pleased to have help getting around the law preventing the U.S. from helping the Contras. (Diamond, 1989, 169) There was a private, largely Christian Right, movement to help them. (Diamond, 1989, 162-164) Among the groups that sent help were elements of the Religious Right especially the Christian Broadcasting Network of Pat Robertson. That organization funneled three million dollars to them. (Diamond, 1989, 171)

\section{ARGENTINA}

As described above, the mere fact that a large percentage of the population is Catholic does not by any means automatically lead to the conclusion that it is a domestic organization responsible to the domestic leadership. The Catholic Church has been vocal on issues such as those under study in this document, abortion/abstinence and gay rights. A point to notice on this section on Latin America is that Popes John Paul II and Benedict XVI have had distinctly anti-abortion and anti-gay beliefs and that they have influenced those below them to push for an anti-gay and pro-life political and social agenda. This has happened globally. According to an article in the New York Times, Bishops have closed down Catholic Charities rather than comply with pro-gay legislation. This has also occurred in such states as Massachusetts, Illinois, and the District of Columbia. (Goodstein) In Latin America, as will be discussed below, the lower clergy have had to fall in line with Church doctrine. Argentina has some unique factors in Latin America. It is relatively ethnically homogenous, has had fewer coups, and has often had a better 
economy. As I show this fits the pattern of characteristics of a country with higher state capacity.

Argentina is a country with high state capacity. In Argentina the mechanisms that allow foreign Christian groups success in countries with lower state capacity do not come into play. Here the reverse happens and legitimacy, cohesion, and education play a role in halting the success of foreign Christian groups. The interplay between foreign effort and the factors of state capacity as used in this document impair the ability of the foreign Christian groups to affect policy.

First, I will discuss the case study country of Argentina, the Latin American country that will represent countries with a high level of state capacity. In the next section, I will discuss the domestic independent variables including legitimacy, cohesion, and education, in that order. Legitimacy is crucial for a country's leadership and a leader will attempt to garner legitimacy. Cohesion is important because it involves how united a country is. A highly fractured country has on average more problems than a country which has more cohesion. Finally education is crucial because this involves a people's ability to receive and then analyze information from differing sources. These are all domestic factors that if work well help state capacity. Argentina will be shown to do relatively well in these areas. The subsequent section will discuss foreign Christian effort in Argentina. This will include the special role of the Catholic Church, efforts to reach the citizens of Argentina, attempts to directly influence the Government of Argentina, and abortion influence. It will then specifically discuss the causal mechanisms. The final section discusses the dependent variable of policy. Here I will discuss the gay marriage legislation that was enacted into law and then I will move on to efforts to legalize abortion.

\section{$\underline{\text { State Capacity }}$}

\section{Legitimacy}

Legitimacy is important for a country's leadership. As described in the African section, without legitimacy it is more difficult for the leadership of a country to effectively lead the people of that country. I will discuss in this section how Argentina is a functioning democracy, and the improvement of the Argentine economy over the past 
decade after overcoming financial chaos at the turn of this century. I will then discuss how the Kirchners, a powerful Argentine political husband and wife team, are supported by the Argentine population, at least for most of their terms in office, and how their leadership has significant support. Finally, I will note that although some recent poll data as of March, 2012shows that President Kirchner is currently showing reduced support in the polls, that this was not the case during most of her administration and certainly not during the time period in which pro-gay marriage legislation was passed.

Argentina, as it now stands, is a democratic country with free and fair elections. The Polity IV data set gives it a score of 8 . Its government has popular support and the economy is functioning well. This is opposed to the situation a decade ago, when it was all but bankrupt. The country is well-run economically and people's lives are better then they were several years ago. People who are doing better tend to give support to those they feel are responsible for the improvement in their circumstances.

The next section will describe Argentina's difficult situation a decade ago and its improvement over the course of the past decade. Taken together with the democratic credentials of Argentina, demonstrates that the government has both legitimacy and popular support.

\section{Background on the Kirchner's Economic Success}

In December 2001, Argentina defaulted on its debt. This precipitated a sizeable financial crisis in that country. Consumption, as well as production, declined greatly and interest rates rose. The balance of trade was also negatively affected and was reversed. (Arellano, 690, 2008) The government went through several presidents. Fernando De La Rua served from 1999-2001. His successor was Ramon Puerta who only served in 2001, and resigned. Puerta's successor was Adolfo Rodriguez who also only served in 2001, and resigned. Rodriguez' successor was Eduardo Camano, who was president from 2001-2002. Camano was replaced by Eduardo Duhalde who left office at the end of his term in 2003. (Argentour.com) Thus Argentina had five presidents in four years. Such a great degree of political uncertainty significantly reduces the government's legitimacy. This work will point to the fact that during the times of uncertainty there was no push for gay rights and freer access to abortion. In fact the state attempted to work with religion. Conversely, a push for gay rights and abortion liberalization saw more positive results 
when times became better. This change occurred under the leadership of the next two presidents: Nestor Kirchner and then his wife, Cristina Kirchner. (Argentour.com) The economy of Argentina stabilized and grew under the leadership of this husband and wife team.

The fact that the people of Argentina chose Nestor Kirchner's wife to be his successor in a free and fair election is further evidence of the support and legitimacy that was given the Kirchner spouses. In fact, the succession of Cristina Kirchner was enabled by the large degree of approval for them by the Argentine people. The two formed a "solid team." (Mohiuddin, 255, 2008/2009) While First Lady of Argentina, Cristina was in control the legislative agenda and assisted Nestor Kirchner in implementing his policies. She has even been compared to Hillary Clinton. (Wrobel, 29) While deciding if he would run again and then face the two-term, term limit in Argentina, Nestor Kirchner allowed Argentina to speculate for several months whether he would step aside at least temporarily in favor of his wife Cristina, a former Argentine Senator. During this time his approval rate was never below 50\%. (Wrobel, 29)

What follows will describe the improvements in the Argentine economy under the Kirchners. Nestor Kirchner was applauded widely for his handling of the economy of Argentina which, as noted above, was severely damaged. "This came as a relief to a country desperately in need of stability and leadership following an unprecedented default on its US\$155 billion debt." (Mohiuddin, 256) Nestor Kirchner oversaw a turnaround of the Argentine economy. Under his stewardship the economy grew at a rate of eight percent in the first three years of his presidency and he cancelled the debt that the country owed to the IMF. As a note, Argentina had paid back \$15 billion to the IMF and other from G7 lenders. (Mohiuddin, 256)

Nestor Kirchner was succeeded by his wife in a free and fair election. Her poll numbers, although now going down due to the global economic crises, remained high after the legalization of same-sex marriage. She won her election to the office of president by $54 \%$ and, as recently as February 2012, she polled over 59\% in her approval rating. This was also after the same sex marriage legislation. Thus she had legitimacy during the time of the same-sex marriage law and her popularity did not decline as a result of that. Her recent tumble to an approval rating of $42.1 \%$ appears to be due to 
financial reasons as Argentina is being impacted by a reduced demand for Argentinean goods in Brazil and China. Still the economy is growing at 5.5\% so Argentina maintains good prospects even though the global financial crisis is beginning to have an impact on the Argentine economy. (Bronstein)

The evidence presented above, makes it clear that the Kirchners, both Nestor and Cristina, have had the legitimacy to lead Argentina. It is unnecessary for now-President Cristina Kirchner to scapegoat homosexuals for political/religious reasons. She has other issues at her disposal in order to maintain her legitimacy. These are a generally successful economy and her clear record of election in elections that were both free and fair. She has instead used her power as president to help homosexuals and give them more rights in Argentine society and under Argentine law, as will be described in the policy section.

\section{Cohesion}

To determine a county's state capacity for the purposes of this document one must also look at the cohesion of the country. Cohesion is critical to a country's well-being. Without cohesion a country will be divided against itself. This section will start with a discussion of Argentina's ethnic and religious homogeneity. It will then delve into Argentina's historical social divides and how they are less pronounced than in the past. It will then point out that the country is more cohesive under the Kirchners than it has been in the past, and that as far as gay marriage goes, there is popular consensus on the issue.

Argentina is relatively homogenous, with a majority of its people having European, mostly Spanish or Italian, ancestry. Whites make up $97 \%$ of the population. The religion of Argentina is overwhelmingly Roman Catholic with 92\% of the population professing the Catholic faith, although with only about $20 \%$ actively participating in that religion. (CIA Argentina) For these reasons, it is the case that there are not great ethnoreligious divisions. There are, however, class divisions that need discussion.

There is a history of class division in Argentina. Former President Juan Peron and his wife Eva Peron based much of their success in politics on exploiting this division by giving their support to those in the working class and those who were impoverished. This tactic worked well until Eva died and Juan was later removed from office by a coup. 
He did, however, later come back to power. He was then replaced by his new wife Isabel Peron.

In 1976, the elected government headed by Isabel Peron was overthrown in a right-wing military coup by the Argentine army. The military charged that Argentina's government was being subverted by left-wing forces that were threatening the country; and that the coup was necessary to protect Argentina from these influences. (Anderson, 2002, 103) To fight this perceived threat from the Left, the new government enacted policies of disappearances, torture, illegal arrests, and even murder. These acts were committed in violation of Argentina's Constitution. This government, a dictatorship, took power in a society which was divided by severe class conflicts. (Anderson, 103/104) The dictatorship received support from the Catholic Church. (Anderson, 109) The dictatorship espoused the view that it was concerned about the decline in Argentine morals and what it viewed as the negative effects of liberalism on Argentine society, such as "sexual license and perversion, feminism [and]... divorce." (Buchanan, 1987, 354) In this, the Argentine dictatorship was also given support by the hierarchy of the Catholic Church who had similar ideological goals. (Buchanan, 350) The Church came to symbolically legitimize the military regime. (Buchanan, 354) As I showed above when Argentina was formerly riven by conflict, in this case class conflict, the Church had a great deal of power in Argentina.

Argentina under the Kirchners is now more cohesive in spite of its class divide. Argentina is also functioning much at an improved level. The Church is no longer used to prop up the regime. The Argentine populace is, in spite of the Catholic Church's opposition to same sex marriage, supportive of the legislation. According to the New York Times, seventy percent of the population supported allowing gay Argentineans the same rights of marriage that their heterosexual counterparts have. (Barrionuevo) According to the same article, the Kirchners, in this high state capacity country, felt that the support for same-sex marriage would be a boon for their political careers and a victory here would score political points and further success for both of them. Ms. Kirchner went on to become president. (Barrionuevo)

The divisions are now less important and less extreme. In spite of the existence of a government that leans to one side of the political spectrum there are no longer political 
killings, disappearances, and torture in the country. This is evidenced by the fact in order to obtain the policy outcomes they prefer, people do not feel the need to resort to violence to the degree they once did. Argentina has a government leaning to the left side of the political spectrum, but there is not, as a result, violence perpetrated in response by the right. Nor is there violence perpetrated by the government against their right-wing opponents. This is evidence that there is more cohesion in Argentine society than there was earlier in its history, when the Catholic Church had more influence. In the reduced amount of authority that the Catholic Church now wields in this more cohesive society one can see that the Catholic Church does not have the power it once did when it was used as a basis for ideological support to a regime. There has been a weakening of the Church compared to the authority they had under the greatly divided society that existed in the late 1970's and the early 1980's.

\section{Argentina's Education}

As argued in the African section, literacy and the ability to critically think are crucial if one is to be able to gather information for oneself and develop informed opinions about issues rather then simply accepting what one is told by leaders in society, including religious leaders. This section will start with a discussion of ability to think about issues as measured by secondary school attendance. It will then discuss literacy rates and how they are important.

Argentina is a good example of a country that has a population that is able to think critically. This can be observed from its level of secondary school attendance. For the purpose of this section, and in comparison to Guatemala, I will use the statistics gathered by the United Nations regarding enrollment, as the data on attendance is missing from the relevant United Nations reports. According to statistics published by the United Nations Children's Fund or UNICEF the secondary school enrolment stands at $80 \%$ for males and $90 \%$ for females. (UNICEFARGENTINA) This demonstrates that amongst both sexes Argentina has a high rate of education insofar as their level of study goes. People in Argentina have been taught the ability to think for themselves as opposed to just accepting the information that has been handed to them.

In terms of literacy, Argentina also scores well. According to the same United Nations UNICEF report $98 \%$ of the adult population has the ability to read. 
(UNICEFARGENTINA) This is critical because if one can not read, one can not, by extension, read reports, newspapers, or even websites that may challenge what is being taught to one. Given that Argentina has such a high literacy rate, one that is roughly the equivalent of the literacy rates in the Developed World, the people of Argentina are able to gather information for themselves.

Given the data presented above it is clear that Argentina has a population that has the ability to obtain information, as is demonstrated by its high literacy rate. It also has a population that can analyze intelligently what information it can gather, as is demonstrated by the percentage of its population enrolled in secondary school. Thus the people of Argentina have an easier time arriving at their own conclusions as opposed to ones put forth by the Church.

\section{Foreign Christian Effort}

While the first independent variable was state capacity, the second independent variable to be discussed is foreign Christian effort. This will start by noting the special role of the Catholic Church. I will describe the important place that the Catholic Church has in Argentine history. I will then go on to discuss how the Catholic Church has reached out to the people of Argentina in an effort to get Catholic policies passed or retained.

\section{Special Role of the Catholic Church}

There is definitely a blurry line between where the Catholic Church stops being foreign and where it starts being domestic. As demonstrated above, the leadership of the Church is foreign and the domestic leaders take their cue from the authorities in Rome. The vast majority of the population is Catholic, and has been since the inception of Argentina, and was even before this during Spanish colonial times. This is different then in Africa where the modern elements of Protestantism are relatively new, at most a little over 100 years old. The Catholic Church influences the people of Argentina through domestic actors such as the average priest who, while being part of the domestic community, also have to take their cue from the Pope and church hierarchy lead from the Vatican. 
The people of Argentina hear Church opinions from the pulpit and from those who attend Church on a more regular basis. This is how the Church influences the common people of the Argentina. The Catholic Church also has newspapers and can get their point across through word of mouth. It has a less obvious foreign visitor system than it was in Africa, with regular communication between domestic church officials and the Roman policy-makers.

Due to its long history of influence, the Catholic Church has a special place in Argentina as it is the traditional religion of the country. The religion is historically interwoven into Argentine society. This is also different inform the situation in countries in Africa. In Africa, the religions are Islam, or newer imports and do not have the same history of being the country's national religion as does the Catholic Church in Argentina. In Africa, the newer beliefs, be they Catholic or Protestant may be deeply felt, but there is not the same historical significance. Argentina, therefore, does have a less well-defined line between the foreignness of the Catholic Church and the domestic sphere. Having said that, the leadership of the Church is still foreign and the rules come from abroad even though many of the people in the country consider themselves Catholic. Membership in the Catholic Church is declining; however, as only $20 \%$ of the Argentine population regularly practices their Catholic faith.

\section{Effort to Reach Citizens of Argentina}

The Pope has reached out to Argentina recently with regard to Argentine law. The Pope has a pulpit in a similar way to the president of the United States. He performs public masses, writes encyclicals, and makes Church policy. He can reach the people of a country without actually meeting them or even traveling to the country. The Pope can make statements; and what he says will be broadcast throughout the globe. This can take the form of media broadcasts of television, or radio, or in print media or on the internet. It can also be broadcast from the pulpit by Catholic clergy whose job it is to preach Church doctrine. Therefore what the Pope says is transmitted to the faithful and placed in the media of predominantly Catholic countries. The Pope thus can communicate without being physically present in a way that is harder for a single Muslim or Protestant religious leader. Although they have media presence each individual Protestant or Muslim leader does not have the same global reach. 
The Pope has used this power to reach out to the people of the entire world, including Argentina. Argentina has drawn the attention of the Vatican recently with its recent and successful attempt at the liberalization of its marriage laws. Argentina recently legalized marriage for gay couples. There was a great deal of conflict in Argentine society in the lead up to this liberalization. Benedict XVI vociferously opposed the gay marriage legislation in Argentina.

In early 2012 Benedict XVI elucidated his opposition towards gay marriage when he described the recently passed legislation as a threat to the traditional family and that it "undermined 'the future of humanity itself." (Pullella Reuters) The Pope addressed the foreign diplomatic corps accredited to the Vatican and stated that marriage as it is constituted "is not a simple convention, but rather the fundamental cell of every society. Consequently policies which undermine the family threaten human dignity and the future of humanity itself." (Pullella, Reuters)

The Church had reached out to Argentineans during the debate that led to the passage of the gay marriage legislation. For months before the passage of the legislation the Church sponsored protests against its enactment. On Argentina's Independence Day, President Cristina Kirchner and the Archbishop of Tucuman debated the issue sharply. (Barrionuevo) Cardinal Jorge Mario Bergoglio of Argentina led the opposition to the legislation. He argued that allowing lesbians and gays to get married threatened the "natural" family with opponents staging a 60,000 man rally against the proposed legislation. (D'Alessandro/Wilkinson LA Times) As a note this rally was claimed to be 200,000 people by the Catholic News Agency1. The rally against the legislation involved Bergoglio and other Christian leaders sending a communication to be read to the protesters stating that common sense should be respected and that gays should not be allowed to marry or adopt children. They stated that children deserved a mother and a father. For the Argentinean government they argued "it is the fundamental responsibility to protect it, to promote it, [the family] to legally preserve it as it is, the union between one man and one women ordered towards mutual help, procreation, the fulfillment and happiness of spouses, the satisfaction of life in its fullness and the raising of children." (Catholic News Agency1) Cardinal Bergoglio stated that same-sex marriage amounted to totalitarianism. He stated that the bill was totalitarian because it did not allow debate on 
what is wrong or right and proposes an "all or nothing" law. (South Atlantic News Agency)

The Church hierarchy has been enforcing its beliefs on lower layers of the Church hierarchy by wielding Church power. As an example of this activity, a priest who had supported gay marriage and had spoken out in favor of gay marriage was punished by his superiors in the Church hierarchy. Father Jose Nicolas Alessio was sanctioned by the Archbishop of Cordoba, Carlos Nanez. He was punished by having his right to say mass and perform marriages revoked. (South Atlantic News Agency) This is a serious punishment for a priest. It also sends a message from above that, at the lower level, priests must support established Church dogma on this issue and that local leaders will be punished for getting out of line.

It is evident from the above that the Catholic Church used the power it had in Argentina to attempt to influence the policy on gay marriage. It strongly opposed and continued to oppose this legislation and similar legislation around the world. It is evident by the Pope's statements and the similar statements put forward by the other leaders of the Catholic Church that they are in strong opposition to gay marriage. Its leaders spoke out and organized anti-marriage protests. It claimed God's authority and the preservation of the traditional family in order to make its case. Its leaders spoke from the pulpits and media outlets that were under their control. The leadership even went so far as to sanction lower level priests who disagree with the Church hierarchy.

The Church has used non-political avenues in order to put forth its philosophy. Catholic opinions are delivered through Church charities, Church media, and Church educational bodies. The Church also tried to influence the Encuentro Nacional de Mujeres or National Women's Meetings in Argentina. Since 1997, the Church has had parallel meetings with women who support their agenda, and has trained Catholic operatives to attend the meetings. They have put up banners and flyers in an attempt to convince people to support the Catholic Position on abortion. These banners said such things as "abortion and Infanticide are Abominable Crimes. God's Commandment is: DO NOT KILL." (Sutton, 104) The Church has also used anti-imperialist rhetoric claiming that foreign groups who support abortion rights are trying to cause the depopulation of Argentina in order to bring the country under the domination of outsiders. They argue 
that leaders who go along with abortion rights are also therefore working against Argentine sovereignty. (Sutton, 104)

Argentina is not unified in its support for gay marriages there are many who oppose it. Argentina remains a conservative country outside of its more liberal cosmopolitan centers but irregardless of this, the legislation was passed by the Argentine Congress and signed into law by President Cristina Kirchner. (D'Alessandro/ Wilkinson LA Times) In spite of strong opposition from the Catholic Church, gay rights groups have been able to make their point in this country with higher state capacity. In Argentina the Church failed to get its way even though roughly $90 \%$ of the population professes the Roman Catholic Faith.

\section{Attempts to Influence Government Directly}

Catholic groups and their allies have lobbied government officials on the national and state level to reduce women's reproductive choices. According to Graciela Rosso the former Deputy Minister of Health, the Pope himself has asked the government officials to repeal women's health rules that give access to contraceptives and reproductive information. One state representative from Santa Fe Province stated that "When we were debating the law [on reproductive women's health] all the representatives received a letter from the Archbishop threatening us even with excommunication [if we voted for the law].” (HRW, 2005, 17)

Under the earlier Presidency of Carlos Menem, Argentine income inequalities had grown; and he led the country in a more authoritarian style. This was a particularly difficult time for forces of abortion liberalization. Menem sought an alliance with the Vatican and through it with the Catholic Church at home. He wanted to make himself immune from criticism by the Church for some of his other social policies that promoted financial inequality. (Blofield, 154) The Catholic Church domestically had wanted to stay away from the abortion message but was overruled by the Vatican who insisted that the local Catholic Bishops take a stand on elections and abortion; thus emphasizing the foreign link. (Blofield, 153) Menem wanted and sought support from the Vatican and the Church in Argentina by taking an anti-abortion stance. Moreover, under his regime the influence of the Catholic Church increased greatly. Moreover, domestic pro-life groups 
were relatively weak, demonstrating that their efforts were not powered by a bottom up effort. (Blofield, 153)

\section{Abortion Influence}

In the matter of abortion, the Catholic Church has promoted polices of social control over women's bodies. (Sutton, 7) The Catholic Church has opposed abortion and contraception. The Catholic Church found an ally in former President Carlos Menem who was supportive of the Church's position on abortion and sexuality. He led Argentina through most of the 1990's. A clear sign of Carlos Menem's support for Church abortion policy was Carlos Menem's decree 1406/98 calling for March 25 as the "Day of the Child to be Born." (Sutton, 103) This was clear support of the Church and a stated opposition to legalization of abortion in Argentina. (Sutton, 103) This church state alliance was a strategy to prevent Catholic criticism of Menem's neo-liberal economic strategy. (Blofield, 154)

\section{$\underline{\text { Policy Effects }}$}

The dependent variable is policy. This section describes how the policy of Argentina has changed in a direction opposed by the Catholic Church. It will first discuss the issue of gay marriage, which has been legalized in Argentina in spite of the opposition of the Catholic Church. It will then discuss abortion policy, where the Catholic Church has been fighting to maintain the illegality of abortion. Abortions remain illegal in Argentina but concrete efforts have been made to legalize abortion in this country.

\section{Same-Sex Marriage}

On July 21, 2010 the President of Argentina, Cristina Fernandez de Kirchner signed legislation to legalize same sex marriage. Argentina thus became the first country in Latin America to allow homosexuals the right to marry and not just have civil unions. The legislation would also specifically equalize inheritance rules and allow for adoption rights for same-sex couples. (Barrionuevo) The legislation was passed by the Argentine Congress on July 15. (Fastenberg) To be clear, the capital of Mexico, Mexico City already had legalized same-sex marriage but Argentina was the first country to do so. The article by Fasteneberg states that resistance to the power of the Church has been a 
recurring theme in much of Latin America that comes up over and over again. President Kirchner has been attempting to place secular law above religious Catholic law and this is an example of what has also taken place in Portugal and Spain. (Fastenberg)

This law not only gives Argentine gay couples the same right to marry as their heterosexual counterparts. The law also allows gay couples to adopt children. Polls support gay marriage and Senator Eugenio Artaza of Argentina stated in an interview that “just like with divorce, women's right to vote and civil marriage, with the passage of time we'll be able to appreciate the benefits of this law." (Grazina) Further, homosexuality is legal, there is an equal age of consent, some parts of Argentina have enacted provisions to ban discrimination and in the 2010 State Department Human Rights Report there were no official discrimination based on sexual orientation. (ILGA, 2010, State Dept.)

Argentina is a country with high state capacity. It has also gone as far as a country legally can to promote gay rights. It has legalized marriage and thus made gay Argentineans full and equal citizens. As will be shown later, this is in contrast to Guatemala which has not done so.

\section{Abortion}

According to the United Nations, abortion is legal in Argentina for the health or life of the mother. It is however, not legal on request. (United Nations Chart, 2007) According to the Center for Reproductive Rights 2000 report, Section 86 of the Argentine Penal Code allows an exception in the cases of the health or life of the women being at risk. Section 86 also allows an exception when the pregnancy is as a result of rape. (Reproductiverights.org) It is, however, also frowned upon by many Argentineans and many doctors refuse to perform abortions leading to back alley abortions, even when the abortion would be considered legal. (Herbert) Argentina has begun serious discussions to legalize abortion completely. In 2011, pro-choice and pro-life groups clashed in the political arena. Protests on both sides of this issue were staged outside of Congress.

In the Argentine Congress there has been activity in the direction of legalizing abortion. A committee of Argentine representatives to Congress voted to send through legislation to the Health and Wellness Department. This is a necessary step before it goes before the Argentine Congress. The vote was 12 in favor of the bill with 7 against the 
legislation. According to Representative Cecilia Merchan there has been a groundswell of support for the legalization. (Marsiglia)

Abortion happens regardless of its illegality. According to a 2000, report by Center for Reproductive Rights, 335,000 to 500,000 abortions happen every year in Argentina. (Reproductiverights.org) According to The Guardian an estimated 500,000 Argentine women per year have abortions. (Herbert) Over 50 Argentine Government Ministers have supported legalization. This level is unprecedented. Usually there are only one or two ministers that openly support a bill. (Herbert)

The fight for or against abortion stood, at the end of 2011, with two bills in the Argentine Congress. One of the bills would guarantee the women a right to have an abortion in the first 12 weeks, or anytime after, if the women's life is at risk or the pregnancy is a result of a rape. Another bill in the Congress is much more restrictive. It would only allow abortion if the mother's life is at risk or the pregnancy is as a result of rape. (ArgentinaIndependent.Com)

On March 13, 2012 the Argentine Supreme Court entered the debate in a more pro-choice fashion. The Argentine penal code Article 86, Section 2, allows for a woman who has been raped to procure an abortion. There was a dispute over the wording. The wording of the article in question states that an abortion could be procured legally "if the pregnancy stems from a rape or an attack on the modesty of a woman of feeble mind." (BBC9) Pro-life scholars argued that this meant that the raped women had to be of feeble mind in order to procure an abortion. The court ruled in favor of the women who had been raped. The court also stated that in future, women who are the victims of rape would no longer need permission from the judiciary to have an abortion. The court claims that they are not stepping into the debate but just clarifying existing law. (BBC9) Nevertheless, this is still a blow for pro-life forces in Argentina who had wanted the rules to be more limited to just women who were mentally disabled as opposed to all women who became pregnant as a result of being the victim of a rape.

\section{Causal Mechanisms}

As a country with higher state capacity, Argentina has fewer causal mechanisms open to exploitation by foreign Christian groups. A discussion regarding the difference between Argentina decades ago and Argentina now elucidates this point. As noted, 
leaders want to remain in power and will peruse relationships that help them in this regard. Now, that Argentina is doing well, and President Kirchner is not courting the Catholic Church. This was not the case with Argentine leaders decades ago. Then, leaders such as President Menem or the military leadership were susceptible to activities that they believed would enhance their legitimacy. Examples of actions based on this mechanism include.

- President Menem cloaked himself in the legitimacy of the Catholic Church by supporting their social views in return for Church support

- Military leaders espoused Catholic social views to gain Church support for their government

Causal mechanisms that were once effective in Argentina are no longer available to exploitation by foreign Christian groups, these are:

- Lack of need on the part of the Argentine leadership for Church based legitimacy

- Lack of need for Church-based cohesion

- More education, leading to less Church control over information.

Taken together, these mean that the leadership can proceed without Church help and without supporting Church policies

\section{Conclusions on Argentina}

In this case study country of a developing country with high state capacity, Argentina, there has been little effect by foreign Christian groups, specifically the Catholic Church and specifically in terms of gay marriage and abortion. The Catholic Church's power in Argentina is declining in terms of policy. This is evidenced by the facts as they stand now. Despite pressure from the Catholic Church on both the gay marriage debate and the debate on abortion, the Catholic Church has not been able to exert enough influence to have its policies enacted, at least not on the important issue of gay marriage. As far as gay marriage is concerned the Catholic Church has lost that battle, gays can now legally marry in Argentina despite the Catholic Church's strong opposition. The matter of abortion is still unsettled. The Catholic Church is not exerting the influence it hoped to have on this issue either. Although the laws have not yet been 
changed to allow women unrestricted access to abortion, there is a distinct movement on the part of the Argentine government to legalize abortion at least in the first trimester. Legislation has been introduced, although as has been noted, the bill has not yet passed. The debate has; therefore, already gone much farther than the Church would like it to go. Church teachings are being challenged in Argentina both in terms of popular opinion and in terms of government policy and action or attempted action.

All of the liberalization of Argentine gay or abortion law occurred recently. Before this was a time when there was very little legitimacy in the government. In a freer society people have more rights generally and in a free democracy those who support gay rights will have more of an ability to make their case both because of increased free speech and due to the ability of pro-gay organizations to lobby decision makers and influence ordinary people who can then vote for like-minded leaders.

Argentina was often ruled by military strongmen who used Church sanction in order to help maintain their leadership. There was also little cohesion as the society was riven by feuding factions. On top of this, there were extra-judicial killings by some groups against members of other groups. The laws were changed or there has been serious consideration of the laws being changed only after Argentina was put back together under the Kirchners. Argentina is beginning to function significantly better and gaining a lot more state capacity. The Catholic Church saw its power wane during this time of Argentine success. It has become a much weaker social actor than when Argentina was suffering a crisis of legitimacy and suffering a major lack of social cohesion.

The Church would like to see a government and populace that support the Church's position on all issues. This is especially true on the moral issues of homosexual rights and abortion, where it claims primacy. There has been a serious attempt to change abortion laws that have a chance of succeeding in the Argentine government. There has been a successful attempt to allow gays to marry. From the above discussion, it is evident that the power of the Church to influence policy in Argentina has weakened as Argentina's state capacity has improved. This country which has a high state capacity has failed to enact policy supported by, and give the desired results for, the (foreign) Catholic Church, its leaders, and their supporters in Argentina. 
In Argentina, the foreign Christian effort did not dovetail with the needs of the leadership. The positive factors of legitimacy, cohesion, and education impaired their efforts, so there was not a positive connection between the independent variables and policy. The foreign Christian groups had more difficulty in influencing legislation in Argentina.

\section{GUATEMALA}

This section discusses the case study country of Guatemala, the Latin American country that will represent countries with a low level of state capacity. It demonstrates that the foreign Christian effort in Guatemala has more of an effect than it does in Argentina, the Latin American country with higher state capacity. Guatemala scores much worse on leading indicators such as education, cohesion, legitimacy, and the Human Development Index. Guatemala also recently suffered through a brutal civil war from which it is still in the process of recovery.

The section starts with a discussion of the important factors of state capacity reviewed in this work: legitimacy, cohesion, and education, in that order as well as foreign Christian effort. The foreign Christian groups are helped in their efforts by the fact that there is little literacy or education and by the fact the leaders need religion for the purposes of unifying the state and giving themselves legitimacy. In this way, the lower state capacity in Guatemala works in tandem with the efforts of foreign Christian groups to help them affect policy.

I will note the level of democracy according to the Polity IV dataset. I will then go on to discuss how, although relatively high on the Polity Democracy Score, Guatemala has achieved this through a focus on internal security as opposed to the wellfunctioning of its society as a whole. I will then go on to point out that, although elected fairly, the winner was not the first choice of the most recent election and had to win a runoff election in which drug cartels and security were the main concerns. After discussing the election I will then discuss the illegitimacy of the judicial system. This will include a discussion of corruption. It will also include how foreign secular groups, have recently gained a great deal of influence over the judicial system in Guatemala due to an attempt to fight the corruption endemic in the Guatemalan judicial system 
After this I will discuss cohesion. The section will discuss the fractures in Guatemalan society, including both ethnic and religious fissures. It will also discuss the some of the effects of the highly destructive civil war that was fought in this country for roughly 40 years. That discussion will close with the societal response to the civil war.

After the discussion on cohesion I will move on to education. The discussion focuses on literacy, which is critical to the ability to obtain independent information, and secondary school attendance which is critical to the ability to successfully analyze information presented. It shows that Guatemala scores poorly on both of these educational indicators

Following the discussion of state capacity, I will then move on to discuss foreign Christian effort in Guatemala. This discussion illustrates ties between Guatemalan leadership and evangelical groups from North America, and includes seven cases. The first case summarizes a brief history of North American involvement in Guatemalan religious life. The second case discusses Pastor Benny Hinn and his activities with respect to Guatemala. The third case describes an association between Guatemala and the Walton Family; Walton connected religious schools, and free scholarships for Guatemalan young people to attend these Christian North American Universities. The fourth case discusses former Guatemalan President Jorge Antonio Serrano Elias and his connection to North American Protestants. The fifth case exhibits the powerful Guatemalan mega-church El Shaddai, its founder Dr. Harold Cabarellos, and its relevant connections to North American institutions. The sixth case discusses the heavily American Protestant influenced regime of General and President Efran Rios Montt. The seventh summarizes Catholic influence in Guatemalan social policy.

After this I will discuss the causal mechanisms that connect state capacity with successful foreign Christian effort. The chapter concludes with a discussion of the dependent policy variables: abortion, and gay rights. It demonstrates the levels of rights for abortion and gays and shows that both are low in terms of acceptance in Guatemalan society. 


\section{$\underline{\text { State Capacity }}$}

\section{Legitimacy}

Although Guatemala has had free and fair elections, the most recent election was won in a run-off election, with the winner having had a minority of the votes in the first round. This situation is unlike that in Argentina, where the government has a large popular majority. In addition, in Argentina the government can reinforce its legitimacy by pointing to a well functioning economy. This is not the case in Guatemala which has a much poorer population.

\section{Last Election}

Much of the controversy in Guatemala's most recent election in 2011 was based on issues of personal security having to do with drug-related gang violence. The three top candidates all ran on platforms of creating a military that was both stronger and focused on fighting crime. The goal was to fight the drug cartels that have infiltrated Guatemalan society directly, a policy that has already cost the lives of 40,000 people. (NYTGuatemala)

The election was not clear-cut. The eventual winner, Otto Perez Molina did not win the election outright and was forced into a runoff election later in the year. Molina scored only $36 \%$ of the vote in the election, well short of the $50 \%$ needed to avoid a runoff election. This leads to the conclusion that he did not receive the support of even a majority of the people of the country.

\section{Judicial System}

The Polity Score might reflect a democratic system in terms of elections but this does not tell the whole story of government. There is rampant corruption in the judicial system. To remedy this, Guatemala created a commission in an agreement with the United Nations, called the Commission Against Impunity in Guatemala or CICG. Under this system international jurists work with Guatemalan prosecutors to present cases. But this system has encountered serious problems. This murder of well-known attorney Rodrigo Rosenberg focused attention on the CICG. Furthermore, in 2010, the popular chief of the prosecutor's office resigned. (NYT Guatemala) 
In spite of this, the CICG has been active. But the fact that the judiciary has been taken over by non-Guatemalans demonstrates the lack of legitimacy of native judicial leaders in Guatemalan eyes. The CICG is ultimately under its foreign influence, and has spearheaded the arrest of several prominent politicians in Guatemala.

The Guatemalan Attorney General Conrado Reyes responded badly to the CICG, led by Carlos Castresana, a Spanish jurist. Reyes began to remove investigators and prosecutors who were working with CICG from office. In 2010, Castresana resigned and accused Reyes of being linked to organized crime. Mr. Reyes denies this but has been removed from office by the highest court in Guatemala. This court declared that President Colom had not followed the law in the appointment of Conrado Reyes as Attorney General in the first place. (Malkin) In June 2010, Costa Rican Attorney General Francisco Dall'Anese was appointed by United Nations Secretary General Ban Ki-moon to be the new head of the CICIG after the resignation of Castresana.

An example of the corruption rampant in the Guatemalan legal system is the fact that under the new system, not run by Guatemalans, a former president, a former dictator's son, two former chiefs of police, and other former officials of the Defense Ministry have been arrested or are in prison. (Malkin) Although the change-over might begin to increase the legitimacy that Guatemalans feel toward their judicial system, the fact that the government is and has been riddled with corrupt officials, not beholden to the legal system, can only have the effect of highlighting the lack of legitimacy of many Guatemalan leaders and an entire branch of the Guatemalan Government.

\section{Cohesion}

Guatemala has a diverse population, with groups that have often been at odds with each other. The largest group in Guatemala is European or Mixed European/Native American sometimes called Ladinos. This group makes up 59.4\% of the population and is considered to be one group by the United States Central Intelligence Agency. Guatemala also has a sizable indigenous community. The breakdown is as follows: K'iche 9.1\%, Kaqchikel 8.4\%, Mam 7.9\%, Q'eqchi 6.3\%, other Mayan 8.6\%, indigenous non-Mayan $.2 \%$, and other . $1 \%$. Native Americans therefore make up a little over $40 \%$ of the population. There is also a language barrier, with Spanish being spoken by $60 \%$ of the population and the remaining $40 \%$ speaking indigenous languages. (CIA Guatemala) 
Spanish is mostly spoken by Whites and Mixed People while indigenous languages are mostly spoken by indigenous people. Although statistics are difficult to gather, the population is approximately $50-60 \%$ Catholic and about $40 \%$ Protestant. The Constitution of Guatemala specifically states the special role of the Catholic Church but there is no official religion. (StateDept.)

Generally speaking, there is tolerance of differing religious groups, but this is not always the case, especially when it comes to relations with native faiths. According to the State Department, Protestants are split between a majority group which avoids ecumenical interaction with other religious groups like Catholics and indigenous beliefs, and a smaller Protestant group which holds a more ecumenically multi-cultural point of view. There is not a great deal of tolerance by Evangelical Protestants towards indigenous beliefs, although there are many indigenous believers in the Evangelical Protestant Community. Some local Protestants leaders make no excuses for their anti-indigenous beliefs and call traditional religions "witchcraft or devil worship," (StateDept.) The Catholic Church has also had some discriminatory practices, such as not allowing indigenous believers to visit holy sites that have had Churches built on them. The Catholics mostly leave indigenous believers alone as long as the indigenous groups do not challenge the dogma of the Catholic Church. (StateDept.)

As far as ethnicity is concerned, there has been conflict. In Guatemala there has been a tradition of domination of indigenous people by the Mixed European/Native American ethnicity. The indigenous population has historically been outside of the mainstream social, political, and economic spheres.

Unlike Argentina which has a dominant ethnicity that makes up $98 \%$ of the population and a dominant religion that makes up $90 \%$ of the population, there divisions within the population of Guatemala are serious, and both religious and ethnic in nature. There was a great deal of ethnic brutality perpetrated by the dominant groups against the weaker ones in Guatemala. A major conflict, largely ethnic in nature, raged in Guatemala from 1960-1996. This war was a great deal more intense than the "Dirty War" in Argentina which, although exhibiting terrible human rights abuses, did not have the same duration or degree of violation of human rights that was experienced in 
Guatemala. This war, sometimes called the Guatemalan Civil War, began during the administration of General Rios Montt.

General Rios Montt was the President of Guatemala for 17 months in the years 1982 and 1983. A Protestant, with connections to the United States that will be discussed below, he has been accused of particular brutality during the Civil War. Under his administration, the army of Guatemala engaged in a "scorched-earth campaign in the Mayan Highlands that included massacres and are regarded as among the most horrific of the war." (Malkin2) In order to defeat small groups of left-wing guerilla fighters his soldiers invaded Native American villages and killed the inhabitants including men, women, and children.

During the Guatemalan Civil War, approximately 200,000 people were killed or disappeared. There were 636 massacres conducted in Native American villages during this 36 year conflict. The current president, President Molina, was part of Montt's army in this war; but he has claimed he was rebuilding during the war and took no part in the massacres. (Malkin2) Under the Montt Administration, the war focused not just on attacking leftists but also on attacking Native Guatemalans as a people. According to the Truth Commission Report that came out after the war, the vast majority of the 200,000 killed were not Ladinos but were of Native American ancestry. The report concluded that $83 \%$ of those killed were of Mayan ancestry while $17 \%$ of those killed were of mixed ancestry. (USIP) Mayans already make up a minority of the population and this leads to the logical conclusion that the vast majority of total deaths and people targeted form an even larger percentage of the Mayan community than the Mixed Community.

Certain groups have, until recently, been denied basic human rights as well as political rights. Native people in Guatemala were targeted by Guatemalan governments, especially the Montt Administration, for terrible treatment. The Native people were killed and their villages destroyed in a way that, for the most part, did not happen to Ladino groups. The Native Guatemalans remember this and it intensifies the divide present in Guatemalan Society between the Ladinos who still wield most of the power and the oppressed Native American people who are largely still out of power. 


\section{Religious Response to Violence}

Garrard-Burnett (1998) postulates that a portion of the conversion to Protestantism in Guatemala was due to the war. The most popular denominations receiving converts emphasized the second coming of Christ believing that there must be great problems and tribulation before Christ comes. This speaks to those suffering through war. The Protestant message thus had more fertile ground for the efforts of foreign groups in war torn Guatemala, specifically of Protestant groups. Similarly, Catholic observance in the tradition of signs, wonders, and baptism in the Holy Spirit also increased. (Garrard-Burnett, 155)

\section{Education}

As in the other case study countries, it is important to emphasize the role of education. Without the ability to think about the issues and do basic analysis, people are more likely to be swayed by ideas presented to them. Literacy is also critical due to the fact that someone who can not read is not able to gather independent information about issues presented to them. Without these two things people are more susceptible to a religious message because they can not critically analyze what they are being told, usually by those in positions of social responsibility; and they are not able to find alternate information to they are presented.

Secondary school enrolment is lower in Guatemala than in Argentina. In Guatemala the enrolment in secondary school stands at $41 \%$ for males and $39 \%$ for females. (UNICEFGuatemala) As a consequence, Guatemala does not have a welleducated, or even moderately well-educated, population. Guatemalans thus have fewer informational alternatives than those who are more educated and thus are more likely to accept information given to them by people of who are respected in their communities and enjoy high social stature, people such as priests and ministers.

Guatemalan literacy rate is also low. According to the 2007 World Almanac the literacy rate for Guatemala stands at $69.1 \%$, significantly lower than that of Argentina. As a result, many Guatemalans can not access information other than what is being told to them. They have no way of reading books or articles that might challenge what they 
were brought up to accept, or told later in life, by those with higher social status like a priest or minister.

\section{Foreign Christian Effort in Guatemala}

Guatemala has been the target of both Catholic and Protestant evangelical effort. Guatemala has the largest percentage of Protestants of any Latin American country.

\section{Protestantism in Guatemala}

Protestantism was first brought to Guatemala during colonial times, but was highly persecuted by the Spanish authorities who favored Catholicism. Protestantism slowly filtered into independent Guatemala during the first half of the $19^{\text {th }}$ Century. President Barrios decreed freedom of worship in 1873. His goal was to use Protestantism to further his Liberal agenda at the expense of Catholic power. Ideas about a country's success were tied to Northern Europe and to Northern American success. These were largely Protestant countries and Protestantism was seen as part and parcel of that success by the Guatemalan leadership. In 1882, Barrios went to New York to work out a border dispute Guatemala was having with Mexico. While there, Guatemalan officials contacted the Presbyterian Board of Foreign Missions who dispatched John Clark Hill to Guatemala. This opened the door to Protestant evangelism in Guatemala. (GarrardBurnett, 12-16) Guatemala still has a majority Catholic population and thus is the target of foreign Christian effort from both faiths.

There has been an increase in Protestant membership in Latin America and especially in Guatemala. According to the Archbishop of Guatemala, this is due to influence coming from North America for the purpose of the United States' dominance. Most of the Protestants are converting to the North American types of Protestantism especially Pentecostalism. This includes believing in absolute biblical truth and supports a commitment to Jesus that is personal in nature. Pentecostals in Latin America combine an orthodox belief in the Bible with a stress on miracles and emotionalism. (Ostling)

\section{Benny Hinn}

As he was in South Africa, Pastor Benny Hinn has been active in Guatemala. Benny Hinn is known to have anti-homosexual beliefs and opposes homosexuality as a sin. Benny Hinn went to Guatemala in 2004, for a crusade. The crusade in Guatemala, 
according to Benny Hinn's website, was filled to capacity. Here the faithful heard what Pastor Hinn referred to as "the clear-cut message of salvation through the blood of Jesus Christ." (BennyHinn.Com) Here he reached many Guatemalans with this message of salvation.

Benny Hinn did not limit his attention to the common people of Guatemala. He also met with an important Guatemalan leader. He met with Alvaro Arzu Irigoyen, the President of Guatemala from 1996-2000, before his crusade. (BennyHinn.Com2)

President Irigoyen has the distinction of being the first post-civil war president of Guatemala. He was elected in January of 1996. His election is therefore important in the minds of Guatemalan people as the leader who presided over the first period of peace in that country for over 35 years. Irigoyen remains active in Guatemalan politics. After his presidential term ended, he was elected three times to be the mayor of Guatemala City, the largest city of Guatemala, as well as that country's capital city.

It is evident that Benny Hinn has been active in attempting to influence Guatemala's people and leadership

\section{The Walton's Involvement in Guatemala}

During the Cold War, the founders of Wal-Mart decided that a good way to fight Communism was to bring people from Central America, including Guatemala, to the United States to study. According to its own website the Walton International Scholarship Program was created with the purpose of exposing "Central Americans to the virtues of democracy and capitalism." (WISP.com) This scholarship was set up in an effort to provide a counter to the Soviet Union, which was bringing Central American students to the U.S.S.R. to study in that country. (WISP.com)

The Waltons paid for the Central American students' education in three Christian schools, the University of the Ozarks which was connected to the Walton Family, Harding University, and the John Brown University, an evangelical university that is an important training school for foreign missionaries and which has expelled its only openly gay student for being gay. Walton selected these schools in Arkansas because "we thought we could stay close to them ... we know what they teach and how they think." (Moreton, 228) Walton paid for degrees for these Central Americans in the fields of business, marketing, and communication. These fields were selected to be funded due to 
the fact these were perceived to be degrees that could help in the fight against Communism. (Moreton, 228)

Each year sixty students are sent to each university for training. These students go on to become white-collar workers who were trained in Protestantism. Many went on to work in United States-based multi-national corporations. Guatemalan connections have been important in this exchange. Reverend Harold Caballeros, a powerful Guatemalan pastor and founder of the Guatemalan mega-church El Shaddai, traveled to John Brown University to talk about recruitment and to help arrange a meeting with the President of Guatemala at that time, President Jorge Antonio Serrano Elias. Elias will be discussed below. The University of the Ozarks worked with the Central Presbyterian Church based in Guatemala City whose top minister had given a 1988, seminar at its Clarksville Campus. (Moreton, 228-230)

Many of the graduates of this program have returned to their home countries. Some have important leadership jobs in successful companies in Mexico and Central America. Other graduates have gone on to develop programs to reduce poverty in their home countries. (WISP.com)

This inculcation of Guatemalan students with Protestant values is evidence of Foreign Christian effort towards them. The students receive a free education, and many return home. By the rule of reciprocity they will have been influenced by the Waltons and the Christian schools that they attended in the United States and the advantages given to them by North American Christians. .

\section{Jorge Antonio Serrano Elías}

Jorge Antonio Serrano Elías was the President of Guatemala from 1991-1993 during the Guatemalan Civil War. He was born in Guatemala City in 1945, and was a Catholic. He got his Doctorate in Education in the United States and he also converted to Protestantism. He came to collaborate with Protestants from the United States to plan reconstruction of Guatemala. In 1991 he was elected President of Guatemala. (CIDOB1) He was the second Protestant President of Guatemala after General Efrain Rios Montt, who will be discussed below. His ongoing joint activities with North American Protestants evince the connection between and the highest government official in Guatemala. 


\section{El Shaddai}

Dr. Harold Cabarellos, the current Foreign Minister of Guatemala, has had a long association with the United States. He states a belief "in the absolute truth of the word of God." (El Shaddai.net) He also believes in "a full commitment to the principles and values of the Kingdom of God." (El Shaddai.net) In other words, he is socially Conservative as a Pentecostal. Cabarellos is the founder of the mega-church El Shaddai, a Pentecostal Church. He enlarged the church "from just a few family members to a multinational neo-Pentecostal empire.” (O’Neill, XIX) His resume includes a law degree from the "notoriously conservative Guatemalan Universidad Francisco Marroquin" (O’Neil, XIX) He also received a Doctorate of Theology from a North American University that he has not disclosed, post-graduate work at Harvard, and a Master's Degree from the Fletcher School of Diplomacy at Tufts University. (O’Neil, XIX) As stated above, he had connections with a Christian program supported by the Waltons to bring Guatemalans to the United States to study in a Christian setting. He is a strong advocate for neo-Pentecostalism as a method for developing Guatemala. (O’Neill, XIX)

El Shaddai is very media savvy and is similar in that way to the late Jerry Falwell of the United States. They record all sermons and have become a bible centered language production company. El Shaddai puts together and packages many fundamentalist statements. They rush to make copies of the sermons and they are in fact ready to sell cassettes of a sermon on the same day. (O’Neil, XX, XXI) El Shaddai has over 500 cells which meet weekly. These cells are made up of 5-16 El Shaddai Members who meet in homes and restaurants to discuss ideas such as morality. (O’Neill, XIX)

Dr. Harold Caballeros places Guatemalan citizenship in the context of Christianity. He supports the idea of individual development through salvation and grace of Jesus Christ. At a private function he stated that Christian citizenship is a way to create a national identity to unite the Guatemalan people who are currently so divided. El Shaddai has stated its objective of a completely born-again country by 2020 , through its 2020 campaign. On another note, they argue that if they succeed in making Guatemala born-again, Guatemala will make it through the apocalypse. (O’Neill, 52-54)

Dr. Caballeros' connections to North America have been demonstrated. He received his Doctorate of Theology in North America and attended other North American 
schools to further his education. As related in the section on the Waltons, he has also collaborated with Christian schools in the United States to bring Guatemalans to certain of the United States' Christian schools.

\section{The Montt Regime}

As stated, Guatemala was a target for the Christian Right. Missionaries sent to Guatemala in the 1970's with the objective of converting the Catholic people of Guatemala to Pentecostalism succeeded to converting General Efrain Rios Montt (Diamond, 1989, 164) to the "rigorous and conservative Pentecostal" (Garrard-Burnett, 139) Verbo Church. He even became a church leader. (Diamond, 1989, 164) General Montt became president of Guatemala in 1982, after a military coup "celebrated by the U.S. Christian Right as a sign of divine intervention in Central America." (Diamond, 1989, 164) He was the first President of Guatemala to be born-again. President Montt's assistant, who was a religious elder, immediately traveled to the United States and met, not only with Reagan officials, but also with leaders of the Christian Right such as Jerry Falwell, Pat Robertson, and Loren Cunningham. In addition, at approximately the same time, the U.S. State department held a briefing for the leaders of the Christian right which encouraged private aid to the Montt Regime. The call for aid was successful. (Diamond, 1989, 164-165)

Montt established an organization to oversee aid to areas damaged by the war. This organization, the Comte Nacional de Reconstruccion (the National Reconstruction Committee), or CRN, was in turn run by the de-facto private organization the Fundacion de Ayuda al Pueblo Inigena (Assistance to the Indian People Foundation), or FUNDAPI. FUNDAPI was largely staffed, operated, and funded by protestant groups such as Verbo and the Partners in the Americas. The latter was tied to Montt and was itself largely funded by conservative Christians based in the United States. The Montt regime encouraged conversion to Protestantism which led to some of the conversions in the war torn areas. Many new Protestant Churches were built in areas that were controlled by Montt's army although growth in Protestantism was occurring both before after the Montt regime ended. However, in terms of total growth the Montt regime made little impact. (Garrard-Burnett, 149-150, 157) 
Pat Robertson, the well known televangelist and right wing politician from the United States "lionized" him. (Martin, 71) Robertson promised the Montt regime a billion dollars but Montt received about twenty million dollars from United States Evangelical Groups before the regime was overthrown in 1983 coup by Montt's Minister for Defense. (Garrard-Burnett, 157, 159) During the Montt regime he became somewhat of a cause celebre for American Evangelicals who sent money to Guatemala for "reconstruction and relief." (Garrard-Burnett, 157) In fact, there was more moral support than money, but the money was also there. (Garrard-Burnett, 157)

The Montt regime brutalized the indigenous people of Guatemala seeing them as supporters of the left. Villages were wiped out. Women and children were killed in gruesome ways. Verbo Church leaders described the killing of these people as the killing of "demons, and the Indians are demon possessed; they are communists." (Diamond, 1989, 166)

General Montt had close connections with Protestants from the United States, as described above. He also worked hard to increase Protestantism in Guatemala. He was for a time the highest leader in that state, and his legacy of supporting Protestantism as described in the Bible lives on in Guatemala. He received this aid in a time of war and used it to further both his and American Protestant's agenda in Guatemala.

\section{Catholic Influence}

Despite the fact that so many Guatemalans are turning to Protestantism, the Catholic Church still has a great deal of influence. A document that was published by the Guatemalan Bishops in 2007, reiterates their stance on abortion. The Bishops attacked what they perceive as the pro-abortion stance of the World Health Organization. In the same letter, they attacked a post-abortion care initiative by the Guatemalan Ministry of Health as being pro-abortion. They called for the Guatemalan government to switch the funds that were to go to this post-abortion care to programs to "be used for the promotion of ethical values to young people." (Catholic News Agency2) They argued that the use of a vacuum in post-abortion care would be a prelude to abortion. People should abstain and be chaste instead of acting in such a way as to create an unwanted pregnancy and that the Government should not pass any legislation that would allow abortion. (Catholic News Agency2) 
In 2008, 71 lawmakers in Guatemala signed an anti-abortion document. This document was a pledge signed by lawmakers in the presence of Guatemalan Archbishop Victor Hugo Palma in which they pledged to defend life from the moment of conception to a natural death. The Arch-Bishop stated at this ceremony that the people who make laws in Guatemala have been elected "to preserve life as a divine gift from God." (Catholic News Agency2) This document had already been signed by lawmakers in other Latin American Countries such as El Salvador and Honduras.

More recently, Guatemalan Bishops held a meeting for presidential candidates for Guatemala's most recent presidential election. It was attended by nine out of eleven presidential candidates. All eleven, except Molina, the ultimate winner, stated that abortion should always be illegal. Molina supported keeping the law as it is with the life of the mother being an exception. All opposed adoption by gays. (Hoffman) The Catholic Church, as was made clear in the preceding section on Argentina, strongly opposes rights for homosexuals and opposes abortion. Their goals for Guatemala are similar.

\section{$\underline{\text { Causal Mechanisms }}$}

Like Uganda, the other low sate capacity case study country, Guatemala has certain types of causal mechanisms that foreign Christian groups can exploit in influencing policy: 1) the need for aid, 2) leader vulnerability, and 3) education or lack thereof.

First consider the use of aid as a mechanism. Guatemala is a country with few resources including educational resources. It therefore needs assistance from outside. The lack of resources that forces Guatemala to welcome help from outside the country's borders is exploited to exercise gradually increasing influence on policy. Specifically:

- the Waltons offer a plan to take people from Guatemala to study at Christian universities in the United States and then go back to Guatemala.

- This education trains Guatemalans who will return to be in positions of leadership

- These Guatemalans will also be trained in Christian beliefs

- As people in higher level positions they can influence Guatemalan Governmental policy 
The second causal mechanism is the leadership's desire to maintain power and control over their country. The main issue with regards to this in the case of Guatemala is the lack of cohesion in that country. Guatemala is riven by ethnic and religious divisions. Supporting Christianity, and especially Protestantism, from outside have been seen as a way to unify Guatemala. In addition, association with the Catholic Church provides a causal mechanism that can be used to strengthen the leadership's legitimacy. Gaining the Church's support does not happen without agreeing to the Church's views on important matters. There is a match between leaders who want to stay in power working with those who give them legitimacy as long as "correct" views are espoused. The foreign Christian Groups have utilized the lack of societal cohesion in the following ways

- Use of Protestantism as a unifying force

- President Barios used it in the 1880's

○ President Mott attempted widespread conversion in the 1980's

- Dr. Cabarellos uses Protestantism as a unifying force today

- Gaining support from the Catholic Church itself

- Public statements on policy by Guatemalan Bishops followed by antiabortion pledges in the presence of a Guatemalan Arch-Bishop

- This is followed by the endorsement of Guatemalan leaders who are pro-life in their legislative agenda through the statement that this is what Guatemalan leaders are meant to do

- Bishops holding sponsoring meetings of political candidates with the goal of fostering a pro-life political agenda

Finally, with regards to education, the mechanism at work here is a simple inability of many people to garner alternate means of information and inability to critically analyze that information that is presented. The mechanisms involved are

- Lack of ability to access differing literature or news sources due to the inability to read

- Lack of ability to intellectually question what is presented by leaders due to poor education levels 


\section{$\underline{\text { Policy Effects }}$}

\section{Gay Rights}

Guatemala has more restrictions on gay rights than does Argentina. In Guatemala the law allows gay conduct. This does not mean all is well for Guatemalan gays. Being gay in Guatemala is quite difficult. Although technically legal, there is official harassment in the sense that police officers are known to harass people of the LGBT community. LGBT people complain that police often wait outside bars and clubs that are patronized by gays and lesbians. On top of this there is societal oppression of the LGBT community in areas such as employment, housing, and education. (State Department 8,27 ) There are no laws on the books to protect LGBT Guatemalans from discrimination or harassment and there are no recognized civil unions or marriage rights, partial or otherwise for gay Guatemalans. Guatemala does have an equal age of consent but no joint adoptions. (ILGA, 2010) Guatemala is a country in Latin America with a lower level of state capacity, and therefore has fewer rights for gays than does Argentina as the foreign Christian groups have more power and influence. Thus it fits with the theory of this work that the country with a higher level of state capacity is more open to foreign Christian groups than those countries with a lower level of state capacity.

\section{Abortion}

Abortion is highly restricted in Guatemala and Guatemalans who want to procure an abortion often have a very difficult time in doing so. Abortion is only permissible when the life of the mother is in danger. The protection for abortion does not include provision for the health or well being of the mother, simply for her life. This legislation has remained unchanged since 1973, when the current exception for the life of the mother was put in place. Even when an abortion is legal, the abortion can only be performed by a physician, and then only if there is consent from at least one other physician. (United Nations) Once again the country with a lower level of state capacity seems to be more influenced by religion and religiously influenced level of abortion restriction is high in the country with a lower level of state capacity. 


\section{Conclusions on Guatemala}

In summary, the above demonstrate three things. The first is that Guatemala is a country saddled with serious problems in the three indicators of legitimacy, cohesion, and education. The country has a corrupt judicial system which favors the connected, its society is split in many different directions, and the education level is poor. It also demonstrates that there is a connection between North American Protestants and both the leadership and the common people of Guatemala. It also demonstrates that, at the instigation of the leader's and common people's religiously influenced belief systems, those who are in power have not granted rights to gays and have opposed abortion. Thus, unlike Argentina, a country that has a higher level of state capacity, Guatemala has withheld rights in the two policy areas of abortion and gay rights.

It is important to draw some connections between the independent variables and policy. The causal mechanisms in play here allow fertile ground for foreign Christian groups to have their policies put in place. The fact that the foreign Christian groups can take advantage of poor education is helpful in that the people of Guatemala have a more difficult time gaining outside information and if they can read other ideas they have a harder time being able to critically analyze that information helps. Also, the connection between religious leaders such as Catholic Bishops and American inspired Protestants who want to unify the country around what they believe is God's law in a country in which leaders are trying to gain legitimacy and in which there are great divisions, underscores the openness of the foreign Christian messages which have born fruit in Guatemala and the connection between the independent variables and policy. 


\section{CHAPTER 6: CONCLUSION}

\section{OVERVIEW}

This dissertation set out to demonstrate that foreign Christian groups have more success in influencing social policy in developing countries with lower levels of state capacity than in developing countries with higher levels of state capacity. It has done so in two separate but complimentary ways. First, it examined two policy areas quantitatively: abortion policy and gay rights, and showed that they are correlated to the human development index, the measure used for state capacity. As the Human Development Index goes down, the level of gay rights also decreases.

Second, it examined the same two policy areas with two sets of case study countries, drawn from two key areas of the developing world: Africa and Latin America. The African studies examined South Africa as a country with high state capacity and Uganda as a country with low state capacity. The Latin American studies examined Argentina as a high state capacity country and Guatemala as a low state capacity country.

Each case study country employed two independent variables. One is the state capacity of the country, which for the purposes of this study is measured by the three areas of Legitimacy, Cohesion, and Education. The next independent variable is Foreign Christian Effort. Each case study country, South Africa, Uganda, Argentina, and Guatemala then focused on two dependent policy variables: abortion and gay rights.

\section{RESULTS}

According to the evidence gathered there were significant attempts at influencing the people and governments in all four of the case study countries covered in this research. The case studies of Uganda and Guatemala show that each was more likely to be influenced by Foreign Christian effort. These countries either retained existing discriminatory policies with regards to gay rights or fewer abortion rights or made attempts to limit rights even further. Their leaders worked with Foreign Christian Organizations in order to establish legitimacy and cohesion. Because the people were also poorly educated they did not have the ability to access and analyze relevant information that might go against what Church leaders and other evangelizers put forth as truth 
The high state capacity countries covered in this study demonstrated a different result. Although there was significant foreign Christian effort put into South Africa and Argentina, the policy outcomes there were different. In spite of evangelizing efforts, South Africa moved to legalize abortion and enacted gay marriage in its country. Argentina behaved similarly in the area of gay rights, and enabled gay marriage in spite of strong foreign Christian effort to not institute such legislation. In the countries with high state capacity, the leadership did not need to attack gays and women in order to maintain legitimacy and cohesion. People could also make up their own minds about issues, having the ability to gather and analyze relevant information as demonstrated by their education levels.

Through both quantitative and qualitative means, this document provides evidence that the initial hypotheses are correct: First, developing Countries are different in the level in which foreign Christian groups can influence them. Second, state capacity is a relevant factor in the ability for foreign Christian groups' ability to influence the policies of Developing Countries. And finally, developing countries with higher state capacity are less easily influenced than developing countries with lower state capacity.

\section{WHERE THIS RESEARCH FITS IN}

This work enhances the understanding of the field of political science in two key areas It increases our knowledge of non-governmental organizations and how they interact with host countries and it increases our knowledge of the importance of state capacity.

As stated, this dissertation fits into the political science literature by broadening our knowledge of how NGO's and non-state actors, specifically religious ones, affect a host developing country. The works of certain types of NGOs such as helping, environmental, multi-national corporation, peacemaking and religious NGOs are part of the literature. This work increases our understanding of a specific type of NGO which seeks to alter social policy in a host country as its primary objective. These wish to influence society in a way that is harmful to weaker elements of the population. As demonstrated in this work, NGOs, specifically religious NGOs, will have more success in a developing country that has a lower level of state capacity than one with a higher level of state capacity. This work also has the effect of increasing our knowledge of the 
importance and role of state capacity in the success or failure of foreign Christian groups. It demonstrates how the level of state capacity helps or hinders the influence of NGOs and non-governmental actors on policy. It therefore contributes to the political science literature in two specific areas: 1) the study of NGOs and non-state actors, and 2) expanding our knowledge of the relevance of the concept of state capacity.

\section{AREAS FOR FUTURE RESEARCH}

This work could be expanded upon in the following ways. First, scholars can look other social areas where foreign Christian Groups might have an effect. This includes a general attack on secularism in the developing world. Scholars may also look at a global fight between secularism in the developed World and religiosity in the developing world. They can also focus on the avenue of Christian and Islamic alliance against secularism in general, and women's and gay rights in particular. Finally, research can be done exploring the influence of other native faiths such as the Hinduism and Buddhism on important social issues such as women's and gay rights in countries such as

India, Nepal, Bhutan, and Thailand, why there has been less Christian impact there, and why native faiths such as Hinduism are not proselytizing to the same degree. 


\section{WORKS CITED}

Aall, Pamela, 1996, Nongovernmental Organizations and Peacemaking, In Crocker, Chester, A., Hampson, Fen, Osler, Aall, Pamela eds., Managing Global Chaos: Sources of and Responces To International Conflict, (pp. 433-444) United States Institute of Peace, Washington, DC

Almond, Gabriel A., Powell, G., Bingham, Jr., eds., 1966. Comparative Politics: A Developmental Approach, Little, Browne, and Company, Boston

Anderson, Leslie, F. 2002, "Of Wild and Cultivated Politics: Conflict and Democracy in Argentina" located in International Journal of Politics, Culture, and Society, Vol. 16, No. 1

Anderson, Mary, B. 1996, Humanitarian NGOs in Conflict Intervention, In Crocker, Chester, A, Hampson, Fen, Osler, Aall, Pamela eds. Managing Global Chaos: Sources of and Responces To International Conflict, (pp. 343-354) United States Institute of Peace, Washington, DC

Arellano, Cristina, 2008, "Default Risk and Income Fluctuations in Emerging Economies" Located in The American Economic Review, Vol. 98, No. 3

Aronson, Elliot, 1999. The Social Animal $8^{\text {th }}$ ed.. Worth Publishers, New York

Barber, Benjamin, R., 2001, Jihad vs. McWorld: Terrorism's Challenge to Democracy, Ballantine Books, New York

Berger, Peter L., 1999. The Desecularization of the World: A Global Overview, In Berger, Peter L. The Desecularization of the World: Resurgent Religion and World Politics, (pp. 1-18) The Ethics and Public Policy Center, USA

Besley, Timothy, Persson, Torsten, 2008, "Wars and State Capacity" located in the Journal of the European Economic Association, Vol. 1 No. 2/3

Blofield, Merike, 2006, The Politics of Moral Sin: Abortion and Divorce in Spain, Chile, and Argentina, Routledge, New York

Bob, Clifford, 2012, The Global Right Wing and the Clash of World Politics, Camridge University Press, New York

Buchanan, Paul, G. 1987, “The Varied Faces of Domination: State Terror, Economic Policy, and Social Rupture During the Argentine "Proceso" 1976-81" Located in American Journal of Political Science, Vol. 31, No. 2

Bull, Hedley, 1977. The Anrachichal Society: A Sudy of Order in World Poitics $3^{\text {rd }}$. ed., Columbia Univesity Press

Burns, James, MacGregor, 1978. Leadership, Perennial,

Cardenas, Mauricio, 2010, "State Capacity in Latin America," located in Economia, Vol. 10, No. 2

Carey, Margret, 2002. Collection of papers from MEG Conference 2002, in Journal of Museum Ethnography, No. 15 
Cialdini, Robert, B., 1993, Influence: The Psychology of Persuasion, Quill, New York

Cohen, Jonathan, Tate, Tony, 2006. "The Less They Know the Better: Abstinence-Only HIV/AIDS Programs in Uganda," located in Reproductive Health Matters, Vol. 14, No. 28

Commins, Stephen, K., 1993. Ethics and Development: costly Choices In. Savitt, William, ed. Teaching Global Development: A Curriculum Guide, (pp. 13-31) University of Notre Dame Press, Notre Dame

Crane, Barbara, B., Dusenberry, Jennifer, 2004., "Power and Politics in International Funding for Reproductive Health: the U.S. Global Gag Rule" Located in Reproductive Health Matters, Vol. 12, No. 24

Crocker, Chester, A., Hampson, Fen, Osler, Aall, Pamela, 1999, The Practitioner's Perspective, In Crocker, Chester, A., Hampson, Fen, Osler, Aall, Pamela Herding Cats: Multiparty Mediation in a Complex World, (pp. 47-62)United States Institute of Peace, Washington, DC

Diamond, Sara, 1989, Spiritual Warfare, South End Press, Boston

Epprecht, Marc, 1998, “The 'Unsaying' of Indigenous Homosexualities in Zimbabwe: Mapping a Blindspot in an African Masculinity," located in The Journal of Southern African Studies, Vol 24, No. 4

Evans, Peter, B., In Evans, Peter, B, Rueschemeyer, Dietrich, Skocpol, Theda, eds. 1985 On the road toward a More Adequate Understanding of the State, in Skocpol, Theda, Evans, Peter, B., Rueschemeyer, Dietrich, Bringing the State Back In, pp. 347366Cambridge University Press, New York

Forsyth, Donelson, R. 1999, Group Dynamics $4^{\text {th }}$ ed., Brooks/Cole Wadsworth New York Fukuyama, Francis, 2011. The Origins of Political Order: From Prehuman Times to the French Revolution, Profile Books, London

Garrard-Burnet, Virginia, 1998, Protestantism In Guatemala: the New Jerusalem, University of Texas Press, Austin

Gibson, James, L. 2005, "The Truth About Truth and Reconciliation in South Africa," Located in International Political Science Review, Vol. 26, No. 4

Gilpin, Robert, 2001, Global Political Economy: Understanding the International Economic Order, Princeton University Press, Princeton

Gleitman, Henry, 1991. Psychology $3^{\text {rd }}$ ed., W.W. Norton \& Company, New York Granitz, Hiel, A. Ward, James, C., 2001, "Actual Perceived Sharing of Ethical Reasoning and Moral Intent Among In-Group and Out-Group Members," Located in Journal of Business Ethics, Vol.330, No. 4

Gruber, Jonathan, and Daniel Hungerman. 2008. "The Church vs. the Mall: What Happens When Religion Faces Increased Secular Competition?" located in Quarterly Journal of Economics No. 123 
Helie, Anissa, 2004, "Holy Hatred" Located in Reproductive Health Matters, Vol. 12, No. 23)

Human Rights Watch, Hostile to Democracy: The Movement System and Political Repression in Uganda, 1 October 1999, 1-56432-239-4, available at:

http://www.unhcr.org/refworld/docid/45dad0c02.html [accessed 9 July 2011]

Inglehart, Roland. and W. Baker 2000. "Modernization, cultural change and the persistence of traditional values" located in the ,American Sociological Review, Vol. 65

Inglehart, Roland and C. Welzel, 2005. Modernization, Cultural Change, and Democracy: The Human Development Sequence, Cambridge University Press, New York.

Irobi, Emmy, Godwin, 2005. Ethnic Conflict Management tin Africa: A Comparative Case Study of Nigeria and South Africa, Beyond Intractability Project University of Colorado

Irwin, Douglas, A., 2005., Free Trade Under Fire Second Edition, Princeton University Press, Princeton

Janssen, Sarah, Spadafora, Vincent, G. 2007. World Almanac and Book of Facts, 2007, World Almanac Books, New York

Kaoma, Kapya, 2009., Globalizing the Culture Wars: U.S. Conservatives, African Churches, \& Homophobia

Kennedy, Brett, 2006, Homosexuals in the Periphery: Gay and Lesbian Rights in Developing Africa University of Nebraska Lincoln-AnthroGroup

Klink, Jenna, 2006, "Uganda and the Global Gag Rule," Located in Off Our Backs and Women's News Journal Vol. 36, No. 3

Lamas, Marta and Bissell, Sharon, 2000. "Abortion Politics in Mexico" 'Context is All"” located in Reproductive Health Matters Vol. 8 No. 16

Lausanne Covenant

http://www.lausanne.org/en/documents/lausanne-covenant.html

Located on October 17, 2011

Levy, Brian, 2004. Governance and Economic Development in Africa: Meeting the Challenge of Capacity Building. In Levy, Brian and Sahr Kpundeh, eds. 2004, Buliding State Capacity in Africa: New Approaches, Emerging Lessons, World Bank, Washington, D.C.pp. 309-330)

Mafela, Lily, 1994. "The Basis for Missionary Education of Batswana Women to the End of the $19^{\text {th }}$ Century," Located in Botswana Notes And Records, Vol. 26

Martin, William, 1999, The Christian Right and American Foreign Policy, Located in "Foreign Policy" Spring 1999, No. 114

Moller, Valerie, Dickow, Helga, Harris, Mari, 1999, "South Africa's "Rainbow People," National Pride and Happiness," Located in Social Indicators Research, Vol. 47, No. 3 
Moreton, Bethany, 2009. To Serve God and Wal-Mart: The Making of Christian Free Enterprise, President and Fellows of Harvord College, United States

Mohiuddin, Yasmeen, , "Christina Fernandez and Nestor Kirchner: Latin America's First Couple" located in International Journal, Vol. 64, No. 1

Nel, Etienne, Binns, Tony, \& Motteux, Nicole, 2001, "Community-Based Development, non-Governmental Organizations and Social Capital in Post-Apartheid South Africa" published by the Swedish Society for Anthropology and Geography

No Author Give, 2000, Women's Reproductive Rights in Argentina: A Shadow Report

No Author Given, 200/2011 Principles and Practices: Scriptural Message and Method

No Author Given, 2010, Uganda Anti-Homosexuality Law Bill is Inherently

Discriminatory and Threatens Broader Human Rights, Amnesty International

Publications, London

No Author Given, 2005. Decisions Denied: Women's Access to Contraceptives and Abortion in Argentina, Human Rights Watch Report

Organski, A.F.K., Kugler, Jacek, 1980, The War Leger, The University of Chicago Press, Chicago

Pierce, Jon, L., Newstron, John, W., 2008, Leaders and the Leadership Process:

Readings, Self-Assessments and Applications, International Edition, McGraw Hill, New York

Rackow, Sharon, H. 2002. "How the USA Patriot Act Will Permit Governmental Infringement Upon the Privacy of Americans in the Name of "Intelligence" Investigations" Located in University of Pennsylvania Law Review Vol. 150, No. 5

Raustiala, Kal, 2001. Nonstate Actors in the Context of Global Climate Change, In Luterbacher, urs, Sprinz, Detlef, F., eds., International Relations and Global Climate Change, (pp. 95-118) MIT Press Cambridge Ma.

Rees, Tomas, James, 2009. "Is Personal Insecurity a Cause of Cross-National Differences in the Intensity of Religious Beliefs" located in The Journal of Religion and Society Vol. 11

Rotello, Gabriel, 1998, Sexual Ecology and the Destiny of Gay Men, Plume Book, USA

Sharlet, Jeff, 2008. The Family: The Secret Fundementalism at the Heart of American Power, Harper Perennial, New York

Shaw, Marvin, E. 1971. Group Dynamics: The Psychology of Small Group Behavior, McGraw Hill, New York

Smith, David The Guardian

http://www.guardian.co.uk/world/2009/dec/10/rainbow-nation-ideal-wane-south-africa Located on February 25, 2012

Stoll, David, 1990. Is Latin America Turning Protestant: the Politics of Evagelical Growth, the University of California Press Berkeley/Los Angeles 
Steegstra, Marijke, 2002. "A Might Obstacle to the Gospel: Basel Missionaries, Krobo Women, and Conflicting Ideas of Gender and Sexuality" Located in Journal of Religion in Africa Vol. 32 Fasc. 2

Stiglitz, Joseph, E., 2003, Globalization and its Discontents, W.W. Norton \& Company, New York

Sutton, Barbara, 2010. Bodies in Crisis: Culture, Violence, and Women's Resistancein Neoliberal Argentina, Rutger's Press, USA

Sweet, James, H. 1996. "Male Homosexuality and Spiritism in the African Diaspora: the Legacies of a Link, located in Journal of the History of Sexuality, Vol 7, No. 2

Tawney, R. H., 1998, Religion and the Rise of Capitalism, Transaction Publishers, London

Tripp, Aili Maria, 2004, "The Changing Face of Authoritarianism in Africa: the Case of Uganda" Located in Africa Today, Vol. 50, No. 3

Vleek, William, 2008, “A Leviathan Rejuvenated: Surveillance, Money Laundering, and the War on Terror" Located in International Journal of Politics, Culture, and Society Vol. 20, No. 1/4

Vora, Jay, A. and Vora, Erika. 2004, "The Effectiveness of South Africa's Truth and Reconciliation Commission: Perceptions of Xhosa, Afrikaner, and English South Africans" Located in Journal of Black Studies, Vol. 34, No. 3

Whitson, Jennifer, A. et. al. 2008. "Lacking Control Increases Illusory Patterns of Perception" located in Science 322

Wrobel, Paulo, 2007, “A Political Dynasty is Born” located in The World Today, Vol. 63, No. 10

\title{
WEBSITES
}

\author{
ABWE Website 1 \\ http://www.abwe.org/about/history/ \\ Located on September 27, 2011 \\ ABWE Website 2 \\ http://www.abwe.org/serve/countries/south-africa \\ Located on September 27, 2011 \\ African Online News \\ Zuma Slammed for Views on Homosexuality, Same-Sex Marraige \\ http://afrol.com/articles/21601 \\ Located on November 5, 2011 \\ A\&U Website \\ http://aumag.org/wordpress/?p=511 \\ Located on October 18, 2011 \\ Allen, John \\ National Catholic Reporter \\ Has the "Real Ratzinger" Come Out to Play
}


http://ncronline.org/blogs/ncr-today/has-real-ratzinger-come-out-play

Located on July 14, 2012

Anti-Defamation Leaugue.Com

Located on December, 142011

Argentinaindepentent.com

Abortion Law is Being Debated in Congress

http://www.argentinaindependent.com/currentaffairs/newsfromargentina/abortion-law-isbeing-debated-in-congress/

Located on March 12, 2012

Argentour.Com

http://www.argentour.com/en/argentina_history/presidents_of_argentina.php

Located on January 24, 2012

Avert.Org

PEPFAR FUNDING

http://www.avert.org/pepfar-funding.htm

Located On November 10, 2010

Multiple Authors

Letter to Congress Regarding Ugandan Anti-Gay Bill

$\mathrm{http}$ //www.adl.org/main_International_Affairs/Letter-to-Congress-re-Uganda.htm

Located on July 20, 2011

Bagala, Andrew AllAfrica.Com

http://allafrica.com/stories/200710151334.html

Located on July 19, 2011

Baker, Mike

http://www.christianpost.com/news/billy-graham-would-like-to-meet-pray-with-obama35307/

Located on October 18, 2011

Barrionuevo, Alexei

Argentina Senate to Vote on Gay Marriage

http://www.nytimes.com/2010/07/14/world/americas/14argentina.html?_r=1

Located on March 13, 2012

BBC1

Zuma Appoligizes For Gay Comments

http://news.bbc.co.uk/2/hi/5389378.stm

Located on November 5, 2011

BBC.Com2

http://news.bbc.co.uk/2/hi/africa/6147010.stm

Located on October 26, 2007

Ross, Will, BBC.Com3

Uganda Prepares for Elections After Years of Civil War

http://www.bbc.co.uk/news/world-africa-12482717

Located on July 9, 2011

BBC.Com4

Uganda Opposition Leaders Sprayed Pink to Stop Rally

http://www.bbc.co.uk/news/world-africa-13355229

Located on July 7, 2011 


\section{BBC.COM5}

Uganda Traders Close Shops in Protest

http://www.bbc.co.uk/news/world-africa-14053516

Located on July 9, 2011

BBC.Com 6

Ugandan police seize Yoweri Museveni 'birthday cake'

http://www.bbc.co.uk/news/world-africa-13979356

Located on July 7, 2011

BBC 7Website

"Wealth Aid for Uganda despite Death Penalty Ban"

http://news.bbc.co.uk/2/hi/uk_news/wales/8427066.stm

Located on February 5, 2010

BBC.Com8

Uganda Gay Rights Activist David Kato Killed

http://www.bbc.co.uk/news/world-africa-12295718

Located on July 20, 2011

BBC.Com9

Argentine Court Decriminalizes Abortion in Rape Cases

http://www.bbc.co.uk/news/world-latin-america-17360739

Located on March 13, 2012

$\mathrm{BBC}+$

South Africa Targets Rainbow Tourists

http://www.bbc.co.uk/news/world-africa-18021964

Located on July 11, 2012

Boyd, Hal

http://www.deseretnews.com/article/700150337/Landmark-evangelical-survey-finds-

both-unity-and-division.html

Located on October 5, 2011

Bronstein, Hugh

Fernandez Numbers Hurt by Slowing Argentine Economy

http://www.reuters.com/article/2012/03/12/us-argentina-fernandez-poll-

idUSBRE82B01U20120312

Located on March 13, 2012

California Digital Library

http://publishing.cdlib.org/ucpressebooks/view?docId=ft5g50071k\&chunk.id=d0e3492\&t

oc.id=d0e3492\&brand=ucpress

http://publishing.cdlib.org/ucpressebooks/view?docId=ft5g50071k\&chunk.id=d0e3492\&t

oc.id $=$ d0e3492\&brand=ucpress

Located on August 23, 2011

Catholic Hierarchy.Org

http://www.catholic-hierarchy.org/bishop/bsandri.html and

http://www.catholic-hierarchy.org/diocese/dxorc.html

Located July 15, 2012

Catholic News Agency

http://www.catholicnewsagency.com/news/nearly-200000-in-argentina-protest-measurethat-would-legalize-gay-marriage/ 
Located on February 4, 2012

Catholic News Agencyl

http://www2.ohchr.org/english/bodies/hrc/docs/ngos/MGSRRG_CESR_PPFA_Guatemal a_HRC100.pdf

located on April 8, 2012

Catholic News Agency2

http://www.catholicnewsagency.com/news/guatemalan_lawmakers_sign_book_of_life_d espite_harassment_from_abortion_supporters/

Located on April 8, 2012

Cave, Damien

Former General to Face a Runoff in Guatemala

http://www.nytimes.com/2011/09/13/world/americas/13guatemala.html?_r=1

located on March 20, 2012

CBS+

http://www.cbsnews.com/8301-503544_162-57398385-503544/white-evangelicals-are-

half-of-gop-primary-voters/

Located on July 12, 2012

Christian Science Monitor Website

"Strike Season" Comes to South Africa

http://www.csmonitor.com/World/Africa/2011/0715/Strike-season-comes-to-South-

Africa

Located on November 9, 2011

CIA World Factbook PPP

https://www.cia.gov/library/publications/the-world-factbook/rankorder/2004rank.html

Located on February 25, 2012

CIA Website (Uganda)

https://www.cia.gov/library/publications/the-world-factbook/geos/ug.html

Located on July 16, 2011

CIA World Fact Book Website (Argentina)

https://www.cia.gov/library/publications/the-world-factbook/geos/ar.html

Located on January 25, 2012

CIA World Factbook Website (Guatemala)

https://www.cia.gov/library/publications/the-world-factbook/geos/gt.html

Located on March 20, 2012

CIDOB (Translated by Babelfish)

http://www.cidob.org/en/documentacion/biografias_lideres_politicos/america_central_y_ caribe/guatemala/jorge_serrano_elias

Located on March 27, 2012

D'Alessandro, Andres, Wilkinson, Tracy

LA Times

http://articles.latimes.com/2010/jul/16/world/la-fg-argentina-gays-20100716

Located on February 4, 2012

El Shaddai.net (translated by Google)

$\mathrm{http}: /$ translate.google.com/translate?hl=en\&sl=es\&u=http://www.elshaddai.net/iglesia/ig lesia-el-shaddai\&ei=jZB_T7DTMKTr0gHb-

cTUBw\&sa $=X \&$ oi $=$ translate $\&$ ct $=$ result\&resnum $=3 \& v e d=0 \mathrm{CD} 0 \mathrm{Q} 7 \mathrm{gEwAg} \& \mathrm{prev}=/ \mathrm{searc}$ 
h\%3Fq\%3Del\%2Bshaddai\%2Bcaballeros\%26hl\%3Den\%26safe\%3Doff\%26biw\%3D102 4\%26bih\%3D519\%26prmd\%3Dimvnsb

Located on April 6, 2012

Fastenberg, Dan

http://www.time.com/time/world/article/0,8599,2005678,00.html

located on March 7, 2012

G20/G8

http://www.g20-g8.com/g8-g20/g20/english/what-is-the-g20-/members-of-theg20/members.71.html

Located on February 27, 2012

Gay Times.uk

http://www.gaytimes.co.uk/Hotspots/GayGuide-action-Country-countryid-872.html

Located on July 11, 2012

Goodstein, Laurie

New York Times

"Bishops Say Rules on Gay Parents Limit Freedom of Religion"

http://www.nytimes.com/2011/12/29/us/for-bishops-a-battle-over-whose-rights-

prevail.html?_r=3\&hp

Located on July 14, 2012

Grazina, Karina Reuters

http://www.reuters.com/article/2010/07/15/us-argentina-gaymarriage-

idUSTRE66E1IH20100715

Located on March 7, 2012

Graham, Billy, http://www.christianpost.com/news/4000-intl-church-leaders-convene-for-worldevangelization-47228/

Located on October 17, 2011

BillyGraham.org

http://www.billygraham.org/articlepage.asp?ArticleID $=2050$

Located on October 17, 2011

http://www.billygraham.org/articlepage.asp?ArticleID=1976

Located on October 17, 2011

Guardian5

East Africa Drought Uganda has Problems but is No Somalia

http://www.guardian.co.uk/global-development/poverty-matters/2011/aug/03/africa-

drought-uganda-no-somalia

Located on February 27, 2012

Herbert, Sian

Argentina's Secret Killer - Illegal abortion

http://www.guardian.co.uk/journalismcompetition/argentinas-secret-killer

Located on March 12, 2012

Hinn, Benny 1, YouTube

http://www.youtube.com/watch?v=HcstbB1J_f8

Located on October 1, 2011

Hinn, Benny2 Youtube

http://www.youtube.com/watch?v=dRpW9IB9VOQ 
Located on October 1, 2011

Hinn, Benny3, YouTube,

Located October 2, 2011

Hinn, Benny 4, Youtube

http://www.bennyhinn.org/articles/southafrica_report.cfm

Located September 25, 2011

Hinn, Benny Website

http://www.bennyhinn.org/events/historic-crusades

Located on March 26, 2012

Hinn, Benny Website 2

http://www.bennyhinn.org/dnld/bennyhinnworldleaders.pdf

located on March 26, 2012

Hoffman, Matthew, Cullinian

Another World: Guatemalan Presidential Candidates United in Opposition to Abortion http://www.lifesitenews.com/news/another-world-guatemalan-presidential-candidatesunited-in-opposition-to-ab/

Located on April 8, 2012

http://humandevelopmentindex.net/

Located on July 11, 2012

Human Rights Watch 2005

http://www.hrw.org/sites/default/files/reports/argentina0605.pdf

Lausanne Website,

http://www.lausanne.org/en/about.html

located on October 17, 2011

Lively Speech 1

http://www.boxturtlebulletin.com/2010/01/06/19081

Located on June 17, 2010

Los Angeles Times.Com

Uganda Lawmakers Remove Death Penalty Clause from Anti-Gay Bill

http://articles.latimes.com/2011/may/12/world/la-fg-uganda-gays-20110512

Located on July 20, 2011

Mail and Guardian Online

Zuma Visits Rhema, Prays for Peaceful Election

http://mg.co.za/article/2009-03-15-zuma-visits-rhema-prays-for-peaceful-election

Located on November 5, 2011

Mail guardian Online 2

Rhema Defends Zuma Visit

http://mg.co.za/article/2009-03-16-rhema-defends-zuma-visit

Located on November 5, 2011

MacLeod, Scott

Zuma on South Africa's Growing Influence

http://www.southafrica.info/news/international/cairo-interview.htm

Located on February 27, 2012

Malkin, Elisabeth

Strains in Guatemala's Experimental justice System 
http://www.nytimes.com/2010/07/04/world/americas/04guatemala.html?_r=1\&pagewant ed $=1 \&$ ref-guatemala

Located on March 19, 2012

Malkin, Elisabeth

In Guatemala Former Dictator is told to Appear in Court

http://www.nytimes.com/2012/01/23/world/americas/efrain-rios-montt-guatemala-ex-

dictator-to-appear-in-court.html?ref=guatemala

Located on March 20, 2012

Marshall, Katherine. WashingtonPost.com

http://onfaith.washingtonpost.com/onfaith/georgetown/2010/02/aid_plus_religion_a_tens e standoff.html

Located on February 27, 2011

Marsiglia, Rafael

Abortion Debate Heats Up in Argentina

http://www.ntn24.com/news/videos/abortion-debate-heats-argentina-6776

Located on March 12, 2012

McCauley

http://www.facebook.com/pages/Ray-McCauley/135754836458991

Located on October 16, 2011

McKenzie, David/Brent Swails

"Funding threat to Uganda's winning AIDS program"

http://edition.cnn.com/2010/WORLD/africa/06/18/uganda.aids/index.html?hpt=Sbin

Located on June 21, 2010

New York Times Argentina

http://www.nytimes.com/2010/07/16/world/americas/16argentina.html

Located January 29, 2012

New York Times Guatemala

http:/topics.nytimes.com/top/news/international/countriesandterritories/guatemala/index. html

Located on March 19, 2012

NPR Website

http://www.npr.org/templates/story/story.php?storyId=129422524

Located on December 9, 2011

Operation Blessing Website 1

http://www.ob.org/programs/hunger_relief/news/2007/hr_2007_0329_southafrica_nutriti on.asp

Located on October 1, 2011

Operation Blessing Website 2

http://www.ob.org/programs/hope_works/news/2004/hw_2004_0330_SouthAfrica.asp

Located on October 3, 2011

Ostling, Richard, N. Time Website

The Battle for Latin America's Soul

http://www.time.com/time/magazine/article/0,9171,156277,00.html

Located on March 27, 2012

Otage, Stephen, Daily Monitor

"Muslims Anger Over Cabinet Posts" 
http://www.monitor.co.ug/News/National/-/688334/1179592/-/c0s22az/-/index.html

Located on July 19, 2011

Pullella, Philip, Reuters

http://www.reuters.com/article/2012/01/09/us-pope-gay-idUSTRE8081RM20120109

Located on February 4, 2012

RHEMA Website 1

http://www.rhema.org/index.php?option=com_content\&view=article\&id=1643:honoringgod-in-our-bodies\&catid=154:2011-august\&Itemid $=527$

Located on October 5, 2011

Rhema Website 2

http://www.charismamag.com/index.php/component/content/article/248-people-

events/632-ray-and-lyndie-mccauleys-divorce-shakes-churches-in-south-africa

Located on September 25, 2011

Rice, Xan

Uganda Considers Death Sentence for Gay Sex in Bill Before Parliament

http://www.guardian.co.uk/world/2009/nov/29/uganda-death-sentence-gay-sex

Located on December 14, 2011

Rossouw, Mandy

Zuma's New God Squad Wants Liberal Laws to Go

http://mg.co.za/article/2009-09-11-zumas-new-god-squad-wants-liberal-laws-to-go

Located on November 5, 2011

Saddleback Website

http://saddleback.com/

Located on February 28, 2012

Samaritans Purse1

http://www.samaritanspurse.org/index.php/Who_We_Are/About_Us

Located on October 18, 2011

Samaritans Purse 2

http://www.samaritanspurse.org/index.php/franklin_graham/

Located on October 18, 2011

Samaritans Purse3

http://www.samaritanspurse.org/index.php/articles/hope_for_south_africa/

Located on October 18, 2011

Samaritans Purse 4

http://www.samaritanspurse.org/index.php/Samaritans_Purse_Today/seeing_both_sides_ of_occ/

Located on October 18, 2011

Sermon Central

http://www.sermoncentral.com/articleb.asp?article=Top-100-Largest-Churches

Located on February 28, 2012

Smith, David

South African Public Sector Strike Endangering Lives

Guardian Newspaper Website

http://www.guardian.co.uk/world/2010/aug/23/south-africa-public-sector-strike

Located on November 9, 2011

South Atlantic News Agency 
http://en.mercopress.com/2010/07/14/massive-demonstration-in-argentina-to-protestsame-sex-marriage-bill

Located on February 5, 2012

State Department Guatemala 2010 Report

http://www.state.gov/j/drl/rls/irf/2006/71462.htm

Located on March 20, 2012

State department human Rights Report Guatemala 2011

http://www.state.gov/documents/organization/160166.pdf

located on April 9, 2012

Sullivan, Amy

Time Magazine Website

http://www.time.com/time/nation/article/0,8599,1873794,00.html

Sussman

Women's News

http://womensenews.org/story/hivaids/060221/ugandas-shift-in-aids-policy-tied-us

Located on June 21, 2010

Tobias, Josh

The other Brown University

Transformation Index

http://www.bertelsmann-transformation-index.de/60.0.html?L=1

Located on March 5, 2012

Transparency International Website

http://www.transparency.org/policy_research/surveys_indices/cpi/2010/results

Located on July 25, 2011

Transparency International Website 2

http://cpi.transparency.org/cpi2011/results/

Located on February 25, 2012

Tulane.edu

http://www.tulane.edu/ internut/Countries/Uganda/ugandaxx.html\#education

Located on July 25, 2011

Unicef Website 2

http://www.unicef.org/infobycountry/uganda_statistics.html

Located on July 29, 2011

UNICEF Website 4

http://www.unicef.org/infobycountry/southafrica_statistics.html

Located on October 20, 2011

UNICEF Website 5

http://www.unicef.org/infobycountry/uganda_statistics.html

Located on October 20, 2011

UNICEF Argentina Report

http://www.unicef.org/infobycountry/argentina_statistics.html

Located on January 27, 2012

UNICEF Guatemala Report

http://www.unicef.org/infobycountry/guatemala_statistics.html

Located on March 20, 2012

United Nations Guatemala Abortion 
http://www.un.org/esa/population/publications/abortion/profiles.htm

Located on April 9, 2012

United Nations Uganda Abortion

http://www.un.org/esa/population/publications/abortion/doc/uganda.doc

located on March 18, 2012

United Nations South Africa Abortion

http://www.un.org/esa/population/publications/abortion/doc/southafrica.doc

located on March 18, 2012

United States Institute of Peace Website

Truth Commision Guatemala

http://www.usip.org/publications/truth-commission-guatemala

World Bank Website

http://data.worldbank.org/indicator/SE.XPD.PRIM.PC.ZS

Located on February 27, 2012

YouTube.com

Maddow, Rachel

U.S. ties to Ugandan anti-gay bill

http://www.youtube.com/watch?v=QXE0D1vupQY\&feature=related

Located on July 7, 2011

U.S. State Department Website

http://www.state.gov/r/pa/ei/bgn/2963.htm

Located on July 11, 2011

2010 Human Rights Report Argentina

http://www.state.gov/documents/organization/160151.pdf

Located on July 22, 2012

Voice of America Website

Fuel Shortages Mark Start of South African Strike Season

http://www.voanews.com/english/news/africa/Fuel-Shortages-Mark-Start-of-South-

African-Strike-Season-125575453.html

Located on November 9, 2011

Womensphere

Ugandan Government Rejects Proposal on Legal Abortion

http://womensphere.wordpress.com/2008/07/10/ugandan-goverment-rejects-proposal-onlegal-abortion/

Located On March 18, 2012

Walton International Scholarship Program

http://www.wispweb.org/history/

Located on April 3, 2012

\section{DATA SOURCES}

$\underline{\text { Abortion }}$

World Abortion Policies, 1999 (United Nations)

http://www.un.org/esa/population/publications/abt/fabt.htm

World Abortion Policies 2007 Wall Chart (United Nations) 
United Nations Department of Economic and Social Affairs, Population Division Data Sources

\author{
Gay Rights
}

International Lesbian and Gay Association Annual Report: A Report That Shaped the Lives of Lesbians, Gays, Bisexuals, and Transgendered Over the Past Year, 1998. by the International Lesbian and Gay Association

International Lesbian and Gay Association Annual Report: A Report on Events That Shaped the Lives of Lesbians, Gays, Bisexuals, and Transgendered Over the Past Year, 1999. by the International Lesbian and Gay Association

Ottosson, Daniel, 2007. State Sponsored Homophobia: A World Survey of Laws

Prohibiting Same Sex Activity Between Consenting Adults, International Lesbian and Gay Association Report, September.

GlobalGayz.com

Ottoson, Daniel, 2009. State Sponsored Homophobia: A World Survey of Laws

Prohibiting Same Sex Activity Between Consenting Adults, International Lesbian and Gay Association Report,

Ottoson, Daniel, 2010. State Sponsored Homophobia: A World Survey of Laws

Prohibiting Same Sex Activity Between Consenting Adults, International Lesbian and Gay Association Report,

\title{
Missionary Activity
}

Barrett, David, B. and Johnson, Todd, M. 2001, World Christian Trends AD 30-AD 2200: Interpreting the Annual Christian Mega census

\section{$\underline{\text { Human Development }}$}

Human Development Report 1998

Published for the United Nations Development Program (UNDP)

Oxford University Press, New York/Oxford

Human Development Report 2002: Deepaning Democracy in a Fragmented World

Published for the United Nations Development Program (UNDP)

Oxford University Press, New York/Oxford

Human Development Report 2007/2008: Fighting Climate Change: Human Solidarity in a Divided World

Published for the United Nations Development Program (UNDP)

Macmillan, New York 